\title{
واقع استخدام معلمات اللغة العربية للتقويم البديل وأدواته في المرحلة الابتدائية
}

\section{المباركه سالم صالحبايكيى}

$$
\begin{aligned}
& \text { هدفت الدراسة البى التعرف على درجة استخدام معلمات اللغة العربية للتقويم البديل وأدواته في } \\
& \text { المرحلة الابتدائية، وقد استخدمت الباحثة المنهج الوصفي المسحي، وتمثلت أداة الدراسة في استبانة مكونة } \\
& \text { من (NV) فقرة، موزعة على ثمان مجالات هي(التقويم البديل القائم على الاتصال، والثقويم البديل القائم } \\
& \text { على ملفات الإنجاز، و الثقويم البديل القائم على التقويم الذاتي، والتقويم البديل القائم على الملاحظة، } \\
& \text { و التقوبم البديل القائم على القلم والورقة، والنقوبم البديل القائم على الأقران، والثقويم البديل القائم على } \\
& \text { الأداء، والتقوبم البديل القائم على المقابلة). تكون مجتمع الدراسة من (9 ـ ه) معلمة من تعليم القنقة، وتم } \\
& \text { اختيار عبنة عثوائبة من (V.) معلمة من معلمات اللغة العربية. أظهرت النتائج أن درجة استخدام } \\
& \text { التقويم البديل جاعت كبيرة وبمتوسط حسابي بلغ (q,9)،كما أظهرث النتائج وجود فروق ذات دلالة }
\end{aligned}
$$

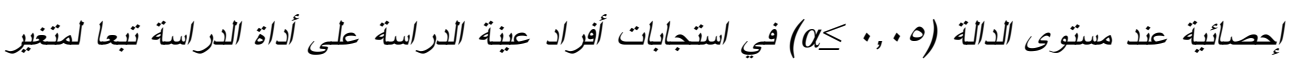

$$
\begin{aligned}
& \text { المراحل التدربينة، وقد جاعت الفروق لصالح فئة (الصفوف العليا)، كما بينت وجود فروق ذات دلالة }
\end{aligned}
$$

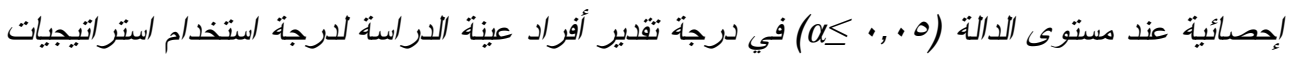

$$
\begin{aligned}
& \text { التقويم البديل تبعًا لمتغبر سنوات الخبرة لصالح فئة (أكثر من • اسنوات)، وكذلك وجود فروق ذات دلالة }
\end{aligned}
$$

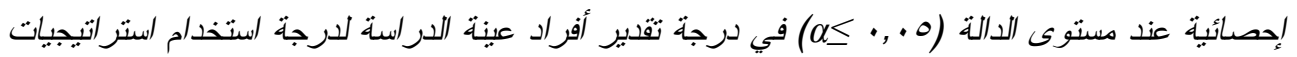

$$
\begin{aligned}
& \text { التقويم البديل تبعا لمتغير الدورات التدربيية لصالح فئة (V دورات فأكثر)، وفي ضوء ما توصلت إلبه هذه } \\
& \text { الدر اسة من نتائج تمَّ تقديم مجدوعة من التوصيات منها: مراعاة دمج التقويم البديل عند تصميم منهج اللغة } \\
& \text { العربية، وبناء دلبل بتضمن كيفية مدارسة استر اتيجيات التقويم الببل وأدواته المختلفة من قبل معلمات } \\
& \text { للغة العربية في المرحلة الابتدائية، و أن تعدل المعلمة على إثراك الطالبات باختيار استراتيجيات التقويم } \\
& \text { البديل التي نتناسب مع أدائهن، وتشبع حاجاتهن. }
\end{aligned}
$$

\section{Abstract}

The study aimed to identify the degree of use of the female Arabic language teachers for the alternative assessment and its tools in the primary stage, the researcher used descriptive approach, the study tool consisted of a questionnaire consisting of (87) itemsdistributed over eight fields (alternative assessment based on communication, alternative assessment based on portfolios, alternative assessment based on self-assessment, alternative assessment based on observation, alternative assessment based on pen and paper, alternative assessment based on peers, alternative assessment based on performance, alternative assessment based 
on interview). The study population consists of (509) female teachers from Alqunfudah educational Administration, while the sample of the study wasselected randomly of (170) female Arabic language teachers. The results showed that the degree of practice was large and with an average of (3.99) and the results also showed that statistically significant differences at the level of the function $(\alpha \leq$ 0.05)in the responses of the study sample individuals to the areas of the study tool, depending on the variable of the teaching stages. The differences came in favor of the upper grades. There are statistically significant differences at the level of the of the function $(\alpha \leq 0.05)$ in the degree of appreciation of the sample members of the study degree of use Arabic language parameters for alternative assessment strategies depending on the variable years of experience in favor of a category of more than 10 years, as well as the existence ofdifferences of statistical significance at the level of the function $(\alpha \leq 0.05)$ in the degree of appreciation of the sample members of the study degree of use of Arabic language parameters for alternative assessment strategies depending on the variable training courses for the category of 6 courses and more, in light of the findings of this study, a number of recommendations were presented including considering alternative assessment when designing the Arabic language curriculum, write a manual that includes how to practice alternative assessment strategies and its various tools by the teachers of the Arabic language in the primary schoolsand that the teacher can engage their students byselecting alternative assessment strategies that will be suitable for their performance and saturation of their needs.

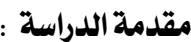

$$
\begin{aligned}
& \text { تتكون العملية التعليمية من عدد مسن } \\
& \text { المكونات، ولعل أهمها التقويم التزبوي الذي لني } \\
& \text { يؤثر ويتأثر ببقية مكونات المنظومة التعليمية } \\
& \text { و التزبوية، ولعل ذللك يعود إلــى أن التقــــيم } \\
& \text { بساعد في إصدار الأحكام على بقية مكونات }
\end{aligned}
$$

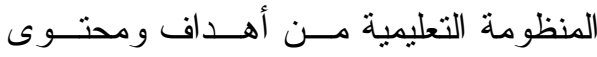

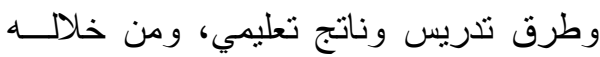

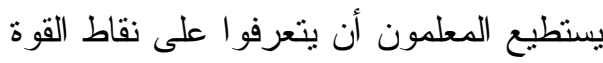

$$
\begin{aligned}
& \text { لدى المتعلمين فيعززونها، ونقاط ضعفهم فيتم }
\end{aligned}
$$

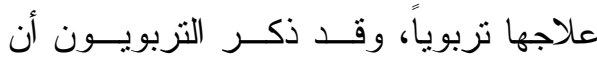

$$
\begin{aligned}
& \text { التقويم التزبوي لله دور كبير ومباثـــر فــي وني } \\
& \text { إعطاء صورة عن النظام التعليمي من جميع دوريع }
\end{aligned}
$$

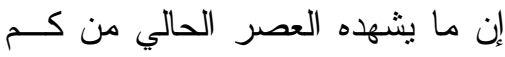

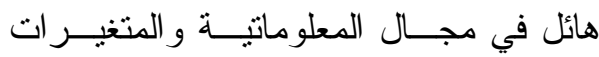

$$
\begin{aligned}
& \text { المتعددة؛ جعلت التربويين يستجيبون لها من }
\end{aligned}
$$

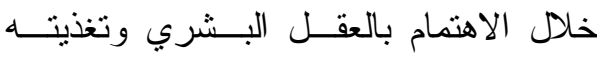

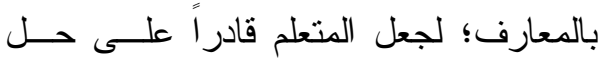

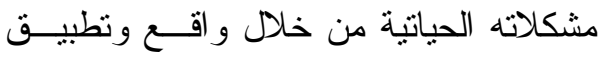

$$
\begin{aligned}
& \text { حقيقي مما ينمي الثقة لديه، وبذللك فإن مفهوم }
\end{aligned}
$$

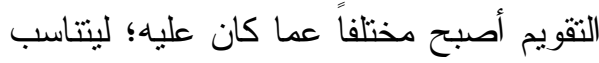

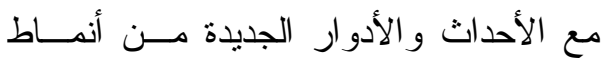

$$
\begin{aligned}
& \text { الحياة وكذلك الفكــر التزبـــوي المعاصـــر } \\
& \text { الحديث (العر ابي، ع . . ب). }
\end{aligned}
$$


الحديثة، ولما لوحظ من شكاوي عديــدة تــم

رصدها من الثقويم التقليدي، والآثار السلبية

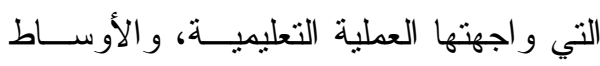
التربوية لعملية التعليم وكونها لا تفيــد فـي ولي

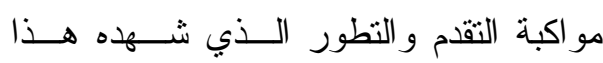
العصر و الثورة العلمية التي ظهرت فيه مما يجعل العملية التعليمية فـي جمــود بـسببـ

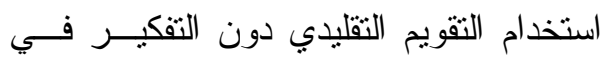
أساليب حديثة وطرق تقويم مناسبة (حمــد،

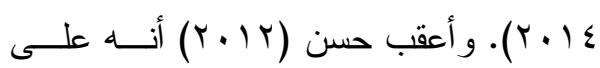

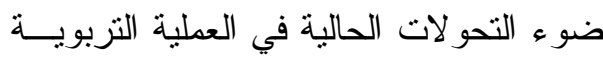

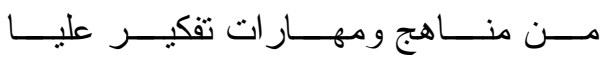
و استز اتيجيات تعليمية وغير ها؛ فإن التقــويم التقليدي الذي يعتمد على الاختبار ات التقليدية

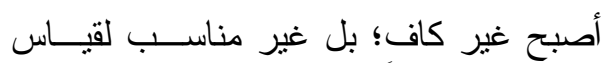
وتقويم التحصيل العلمي للمتعلمين. يُعدُّ معلم اللغة العربية الموجه الأساس في تعليم اللغة العربية وتقويمها مــن خــلهل

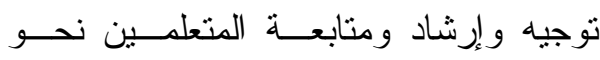
التطوير و التحسين لجميع مهار اتهم اللغويـــة، ونئة وتجويد طرق التدريس، وتحسـين أســاليب التقويم؛ بل البحث عن وسائل تقويمية مناسبة

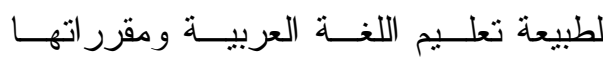
الدراسية من خلال استخدامهم للتقويم البديل و أدو اته و استز اتيجياته؛ لتقويم ما يتعلمونـــهـ

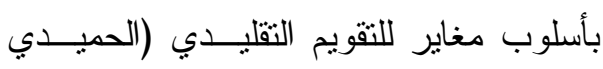

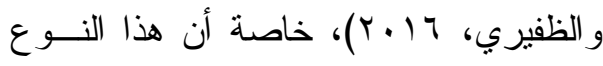

جو انبه وكافة مكوناته؛ لذللك فــإن تطـــــير التقويم التربوي و أساليبه أمسـر فـــي غايسـة

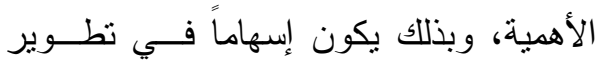

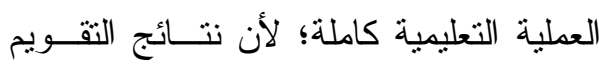

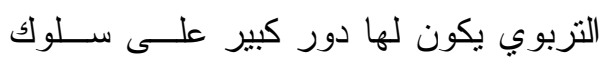
المتعلم و أدائه ومهار اته و تقكيره و وكذلك تتمية دون المسؤولية تجاه التعلم (حسن، r I r). وقد ذكر العلوي (r . . r) أن التقــويم هو العملية و الأداة التي يتم بو اسطتها نجـــاح النظام التعليمي سواءً على مستوى المعلم أو الأهداف التربوية أو الطريقة التدريسية، وأن عملية التقويم ليست مجرد طريقــة اختبـــار و إنما هو أساس إعداد المواقف التعليمية التي لمئي تتتاسب مع ظــروف المتعلمــين وفــروقهم

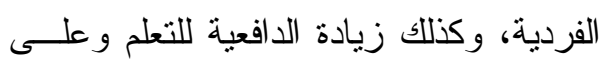
ذلك فإن التقويم الجيد هو ذلك التقويم الــذي ولـي

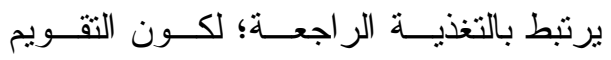

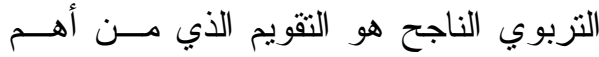
أهدافه إعلام المتعلمين بما تعلموه و التقليــلـل من التخوف من المادة التعليمية أو المعلم أو الهو

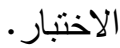

علاوة على ماســـق؛ فــإن التقـــويم

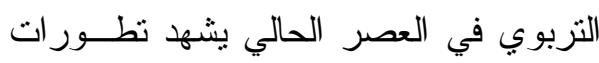

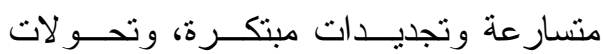

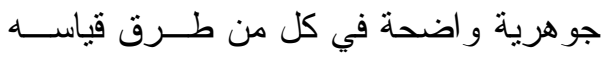

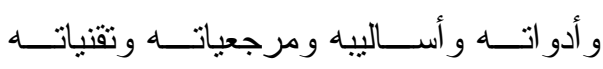

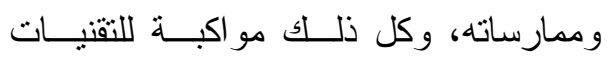


في الأداء وتقويم نموه وتطـــويره، وكــللك

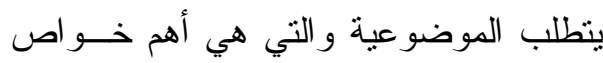
ومز ايا التقويم البديل التي يتسم بها وكـــللك الته

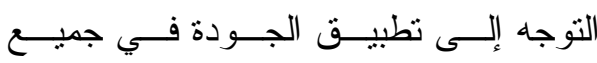

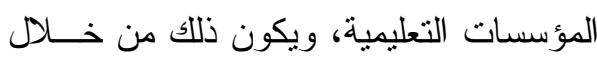

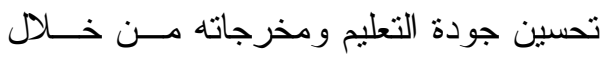

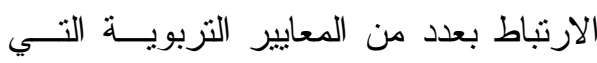

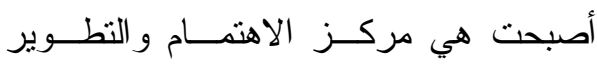
عوضا عن ارتباطها بعـدد مــن القـضايا

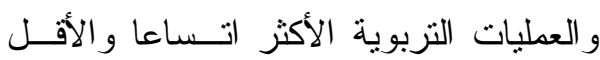
التصاقا بأداء المتعلم بذاته من خلال أدائــــ؛

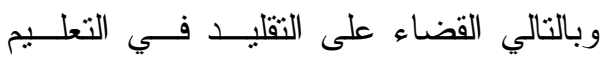
و التوجه نحو الأداء و الحكم على أداء المتعلم بصورة و اضحة بعيدة عن الطريقة التقليديــة

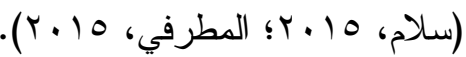
ونظر أ للاور الذي يقدمه التقويم البديل في العملية التعليمية بشكل عام وفي تــدريس اللغة العربية على وجه الخصوص، ومناسبة التقويم البديل مع حاجات المتعلمين وملاءمته ولهنه

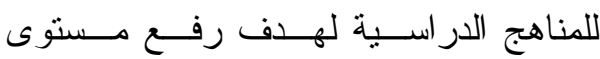

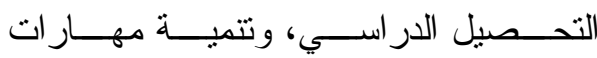
و اتجاهات وميول المتعلمين في تعلـــم اللغـــة العربية بالإضافة إلى كون التقــويم البـديل

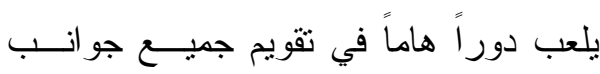
المتعلم الثخصية و المتابعة الجيدة في عملية التذريس، فإن هذه الدر اسة قامت على معرفة واقع استخدام معلمات اللغة العربية للتقـــويم
من التقويم يتميز عن غيره بكونه يركز على

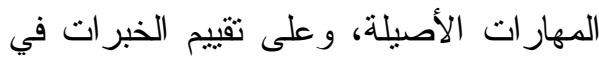

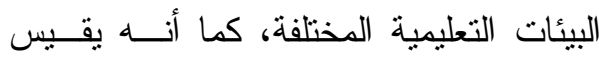

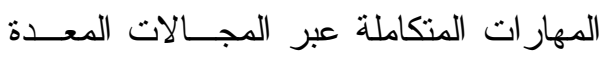
لذلك (Kleinert \& Kearns, 2010). إن أبي عملية تعليمية تتطلب مهار ات

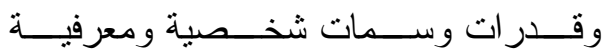
تخصصية بحيث تعطي صورة متكاملة عـن ونـ

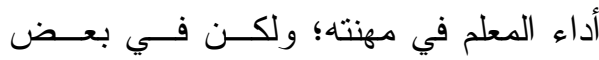
الأحيان قد يكون قياس كل جانب من جوانب

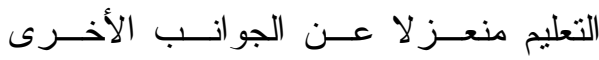

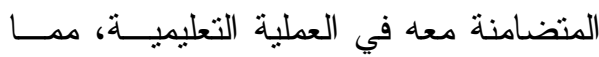

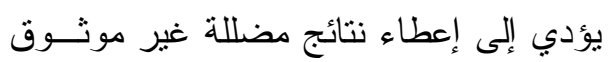

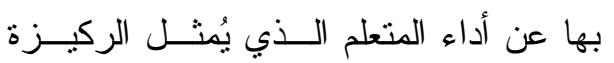

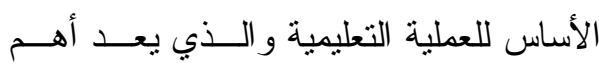
الركائز الأساسية التي يقوم عليهـــا التقـــــيم البديل في منظوره الجديد بوصفه أداة جديدة للتثويم، ونظر الكثرة الانتقادات التي وجهت لبته للتقويم التقليدي فقد أستخدم التقــويم البــديل لعدد من الأسباب منهـــا، التطــــور الفكـري

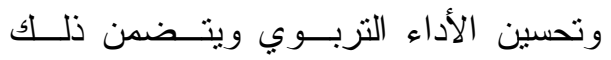

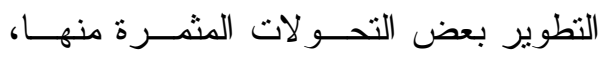

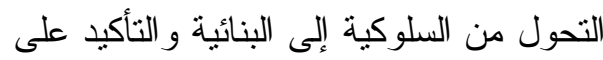

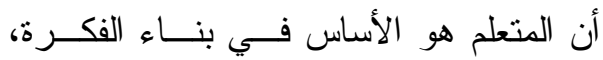
و القيام على نشاطه من خلال أساليب تربوية

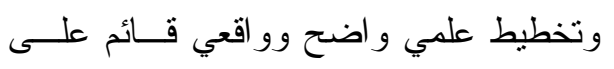

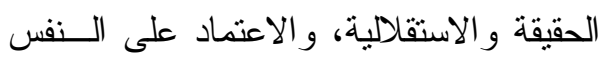


إعطاء المعلم معلومات عن كفايــة المــتعلم

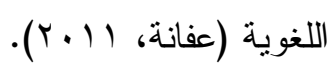

فالتقويم البديل و أدو اته و واســـتر اتيجياته يعد فكراً تربوياً فريداً جديداً، كما يعد أحســ وليد

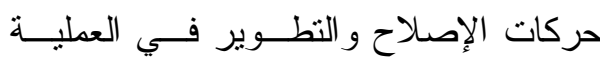

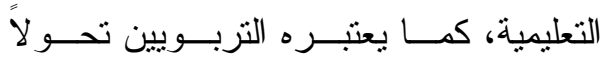
جو هرياً لجميع الممارسات التي كانت سائدة بشكل تقليدي في القياس و التقويم، وكونه أداة قاصرة في تقويم المتعلمين وتقدير تحصيلهم

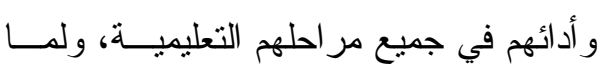

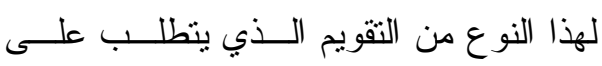

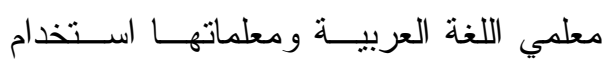

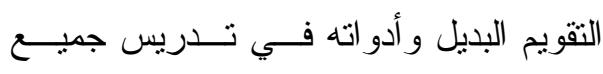

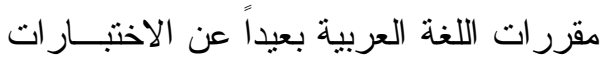

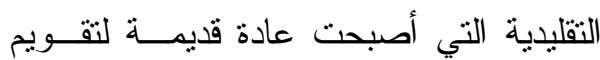
المتعلمين، ولكون التركيـز علــى أســاليب

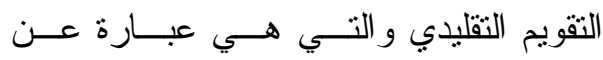

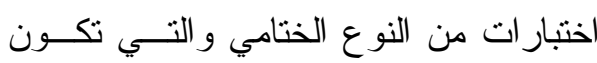
أهدافها عامة وفي نهاية كل فصل در اسي أو لون مرحلة در اسية وذلك بهدف إعطاء الدرجات

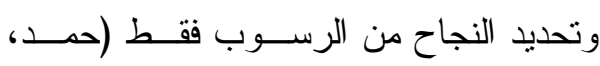

$$
\cdot(r \cdot) \leq
$$

لقد أشثارت مجموعة من الدراســات

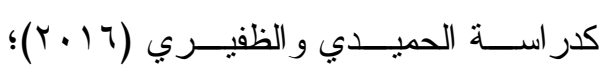

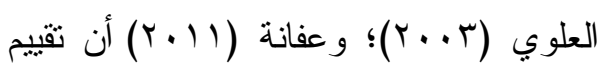

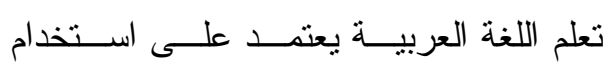
استز اتيجيات التقويم التقليدية التي تعتمد على لتعلى
البديل في المرحلة الابتدائية باستخدام أساليب التقويم البديل المختلفة.

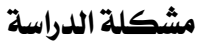

إن ماتثـهـه المنظومة التعليميــة مـن

تطورات شاملة لعدد من العمليات التزبويـــة التي تسهر في تطـــوير وتحــسين العمليــة التعليمية وخاصة عملية التقــويم التزبــوي و أساليبه و أدو اته، وكون أن التقويم الثقليــدي قائم على الاختبار ات التحصيلية التــي تهــتح

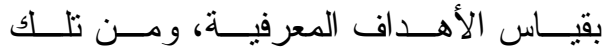
الاختبار ات اختبارات القلم و الورقـــة، فــان الاتجاهات الحديثة قائمة على تطبيق أساليب تقويم حديثة في التعليم والتعلم فـي جميـع المو اد الدر اسية عامة، وفي تعليم وتعلم مو اد اللغة العربية خاصة (حمد،ع ا • ب). لقد أصبح هناك اهتماماً متز ايداً تجــاه جميع الممارسات الحديثة في التقويم التزبوي

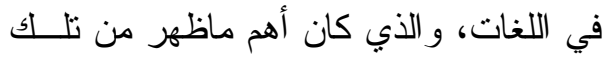

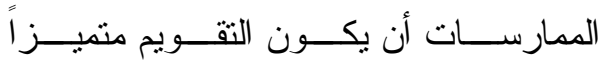
بالمصداقية العالية و الو اقعيــة فــي جميــع

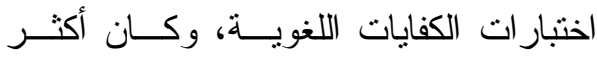
التزكيز على مهارات الاتصال اللغوي، وبناء؛ على ذللك فقد توسع استخدام التقويم البــديل و الذي كان له أكبر الأثر في تقدير الكفايــات

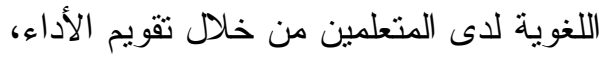
وكذلك الاعتماد على التقويم الذاتي؛ لقــدرة المتعلم اللغوية والتي لها الدور الكبيــر فــي 
r- تحديد درجة استخدام معلمــات اللغـــة

العربية لاستر اتيجيات التقويم البــديل

و أدو اته تبعا لمتغير الصفوف الدر اسية

(الصفوف الدنيا و الـــصفوف العليــا)،

وسنوات الخبرة، و الدور ات التدريبية.

ثناتيًا: الدر اسات السابقة

اهتمــت

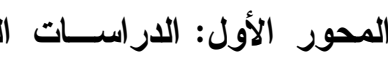
بالتقويم البديل وأدواته

Caliskanand

(2010) -

Kasikci تطبيق التقويم التقليدي، و التقويم البــديل و أدو اته بو اســـطة أســـاتذة فــي العلـــوم الاجتماعية، و استخدمت الدر اسة طريقــة الفحص كنموذج كأداة لجمــع البيانــات، وتكونت عينة الدراسة من (Y) (Y) معلمًا للار اسات الاجتماعية، وقد تم اســتخدام استبيان كأداة للدر اسة من قبل البــاحثين، وتوصلت الدراسة إلى أن المعلمين الذين يطبقون أدوات التقويم التقليدية، لا ســيما اختبار الاختيار من متعــدد، و الاختبـــار المفتوح، و الإجابة القصيرة، و اختبــار ات مله الفر اغات أقل من المعلمــين الــذين يفــضلون تعبينـــات المــشروع و الأداء لأساليب التقييم البديلة و أدوات التقييم في التعليم الابتدائي، و الدر اسات الاجتماعية.

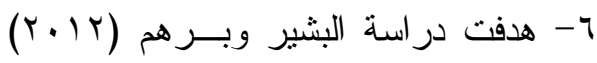
إلى استخدام استر اتيجيات التقويم البــديل

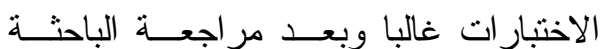
للأدبيات السابقة لم تجد در اسة اهتمت بتقييم و اقع استخدام استر اتيجية التقويم البديل مــن قبل معلمات اللغة العربية في تقــويم تعلـــم طالباتهن في المرحلة الابتدائية فــي تعلــيم محافظة القنفذة. وبناءً على ذلك فإن مــشكلة الدراسة الحالية تتمنل في التعرف على واقع استخدام معلمات اللغة العربية للتقويم البــديل و أدواته في المرحلة الابتدائية.

أسئلة الدراسة

ا- ما درجة اســتخدام معلمــات اللغـــة

العربية لاستر اتيجيات التقويم البــديل في المرحلة الابتدائية؟

r- هل توجد فروق ذات دلالة إحــصائية

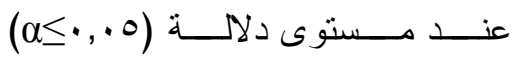

بــين متوســــات اســتجابات أفــر اد العينــة لارجــة اســتخدام معلمــات اللغة العربية لاســتر اتيجيات التقــويم

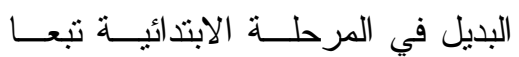

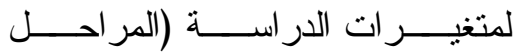
التدريسية، وسنوات الخبرة، الدورات التدريبية)؟

أهداف الدراسة

هدفت الدراسة الحالية إلى تحقيق الآتي:

1- تحديد اســـر اتيجيات التقــويم البــديل

و أدو اته المستخدمة في تذريس اللغــة العربية في المرحلة الابتدائية. 
ملفــات الانجـــاز لمجــالات المتعلمــين و المعلمين و التوظيف و البر امج لله قــدرة

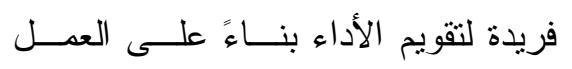
المحدد الذي يوضـح القدرة والإمكانــات. وقد ذكر الباحــث أن ملفــات الإنجـــاز المثالية هي وثثيقة "حية" تسمح بــالتعبير الفردي عن العمل مع الالتز ام بمعـايير

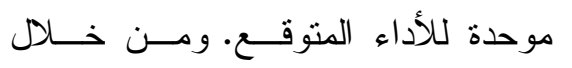
المناقشة فإن التقويم يقوم علــى المــتعلم

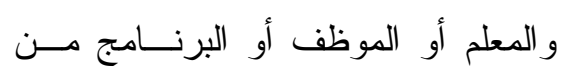

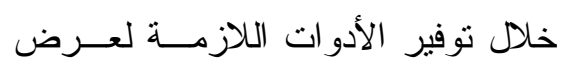
أدائه الحقيقي باستخدام ملفــات الإنجــــاز يستحق إعادة النظر • بأه ل - أما در اسة جودة (ع ا . ب) فكثفت عــن ملف الانجاز كأداة نقويم بديل من وجهة نظر معلمي الرياضيات في قطاع غـزةة،

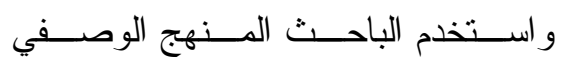
التحليلي، وتكونت العينــة مسن (10. (1) معلماً ومعلمة، و اســتخدمت الاســتبيان كأداة تكونت من (ع) محاور يتضمن كل

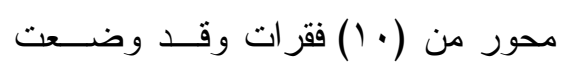

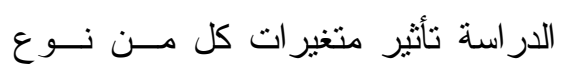

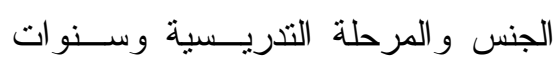
الخبرة على استخدام ملفات الأعمال كأداة تقويم بديل. توصلت هذه الدر اسة إلى أن

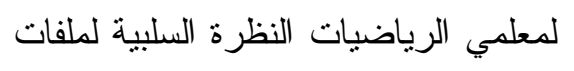

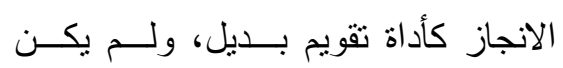

و أدو اته في تقويم تعلم الرياضيات و اللغة العربية في الأردن، و استخدمت الاستنيان

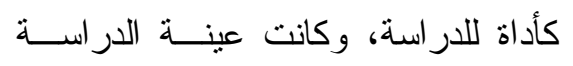

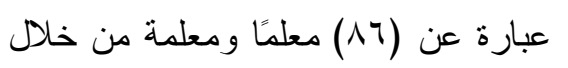

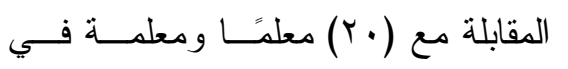
تخصصي الرياضيات و اللغـــة العربيـــة

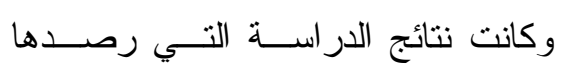
الباحث على النحو التــالي: اســتر اتيجية القلم والورقة كانــت أكثــر اســتخدامًا

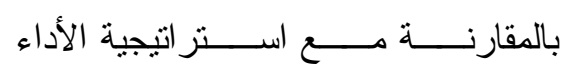

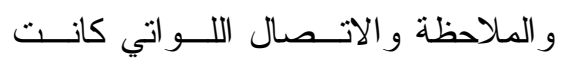

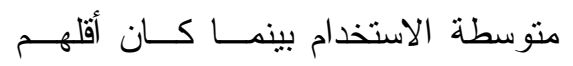

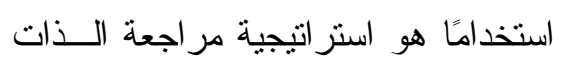

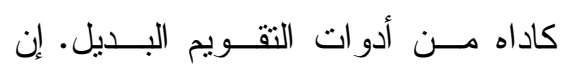

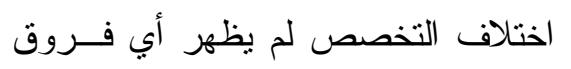

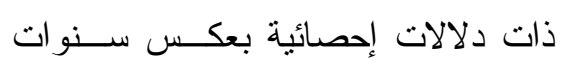

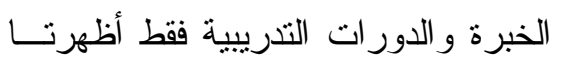

$$
\text { فروق ذات دلالات إحصائية. }
$$

Sandford و واتجكت در اسة (2013) land Hsu دراسة نظرية من خلال مراجعة وإعادة النظر وتفعيل استخدام ملفــات الإنجــاز كأداة من أدوات الثقويم البديل، وقد خرج

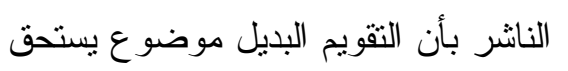

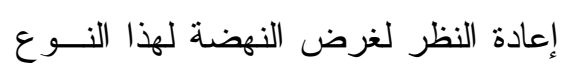

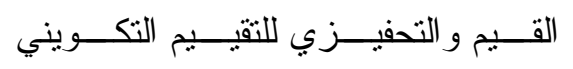
و الختامي. كما أضاف الباحث بأن نطبيق لأن 
المعلمة ودليل الطالبة، وتكونــت عينــة

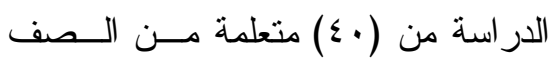

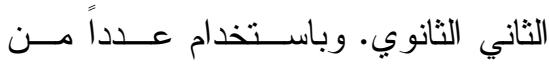

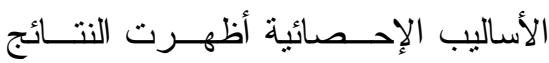

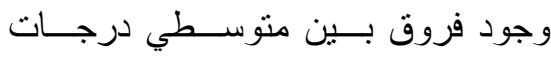

الطالبة بين كل من المجموعة التجريبيــة و المجموعة الضابطة وكانت تلك الفروق

لصالح المجموعة التجريبية.

ـ ا- وسعت در اسة الحارثي (10 • ب) إلـى

التعرف على مــدى اســتخدام أســاليب

التقويم البديل في بعــ الكليــات فــي

جامعة شقرا من وجهه نظر المتعلمـين

و أعضاء هيئة التدريس، وتم اختيار عينة

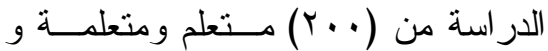

(Ar) عضو هيئة تــدريس، وتوصـلت

الدراسة إلى أن الأسئلة الموضوعية هي

الأكثر شيو عا وتفضيلا لــدى الكتعلمــين

و الأسئلة الثفوية هي الأقل تفضيلا، وقد

وجد اختلاف بــين الكليـات و الأقـسام

العلمية و الأدبية يعود إلى اختلاف طبيعة

$$
\text { البرنامج و المقرر ات الدر اسية. }
$$

Y 1 - هدفت در اسة خير (10 • Y) إلى در اسة

تحليلية نظرية عن التقويم التزبوي البديل

ودوره الإيجابي فـي مقيــاس تحـــيل

المتعلمين وتقويم أدائهم بمر احل التعلــيم

المختلفة. اســتخدمت الدر اســـة المــنهـج

الوصفي التحليلي في معالجة المحتــوى
لمتغير ات الجنس وســـوات الخبــرة أي

فروق ذات دلالات إحصائية فـي حسين

ظهر هناك فروق ذات دلالات إحصائية

لمتغير المرحلة الدراسية.

r ا - أما در اسة Letina فقد سعت

إلى تطبيق الثقويم التقليدي و الثقويم البديل

في تدريس العلوم و العلوم الاجتماعية في لهي

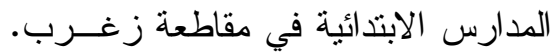

وكانت النتائج التي نم الحــصول عليهـــا

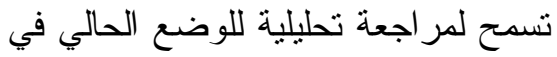

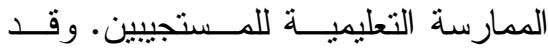

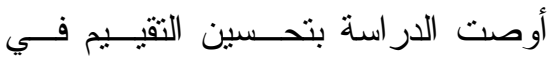

ممارســة عمليــة التــــريس، و إعـــادة

تصور ها واستخدامها موجهة نحو تقيــيم

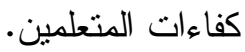

با - في حين هــدفت دراســة الأحمــدي

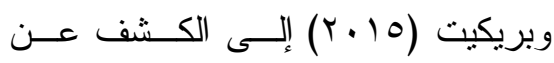

فعالية إستر اتيجية مقترحة قائمسـة علـى الـى

الدمج بين الفصول المقلوبة التقويم البديل

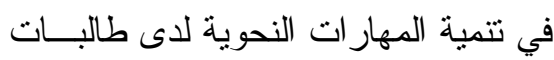

الصف الثاني ثانوي، و استخدمت الدر اسة

المنهج التجريبي المعتمد علــى تــصميم

مجمو عة تجريبيــة وأخــرى ضــــابطة،

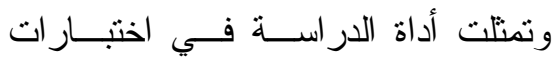

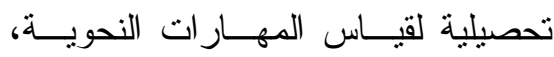

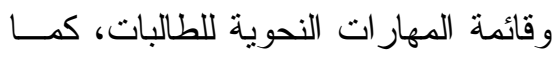

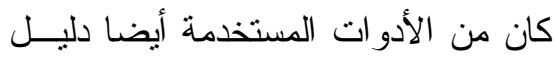




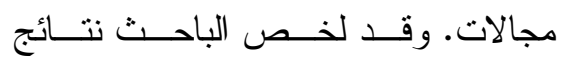

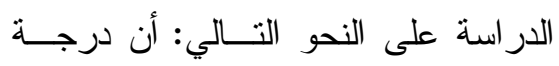

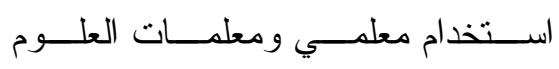
لإستر اتيجية التقويم البديل و أدواتـــه فــي ملـي

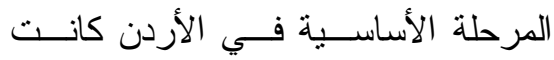

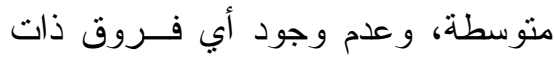

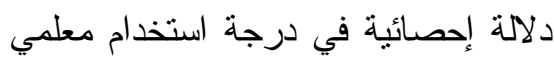

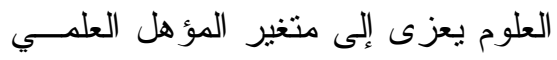
أو الخبرة أو نوع الجنس.

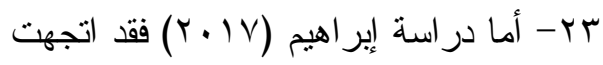
إلى التعرف على درجة استخدام المعلمين

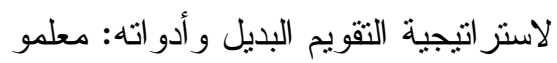

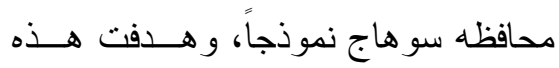

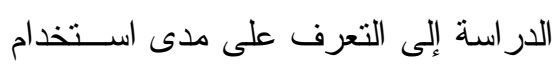

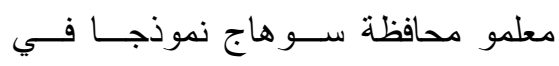

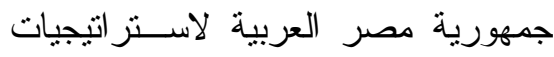
التقويم البديل. وطبقت الدراسة الاستبيان

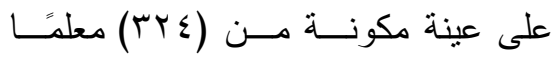

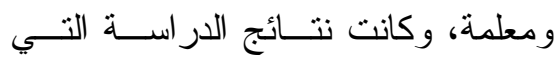

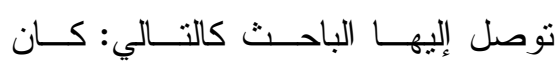

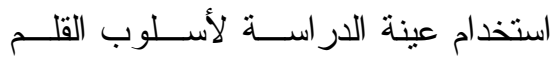
و الورقة عالية في حين أن التقويم المعتمد

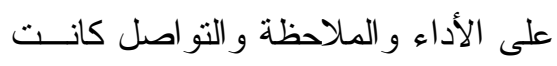
متوسطة بينما أضعف الأساليب استخداما

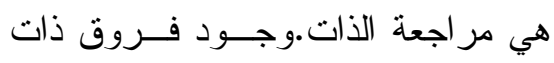

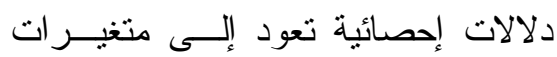
الدراسة كالتخصص وســنوات الخبــرة و الدور ات التدريبية.

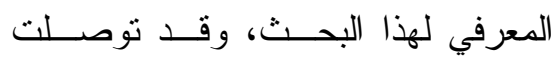
الدر اسة إلى عدد من النتائج منها أهميـــة التقويم البديل في كونه يمكن المتعلمـين

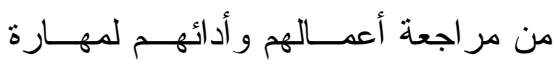

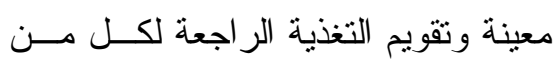
المعلمين و المتعلمين معاً.

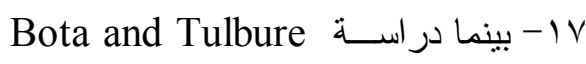
(2015)سعت إلى تحليل العلاقـــة بـين

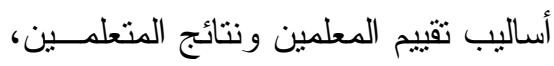

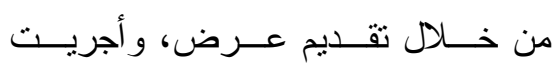
دراسات مقطعية على عينة مكونة مــن

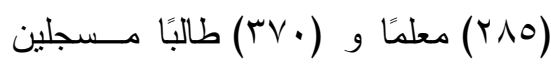
في التعليم الثانوي الروماني. واستخدمت

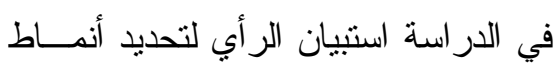

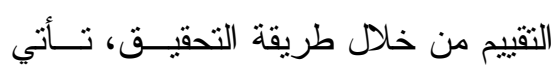

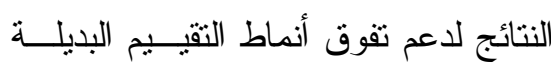

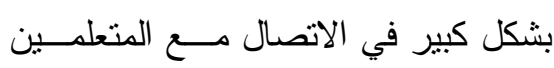
نتائج المدرسة.

19- و اتجهت دراسة الحر احسشة (17 (1)

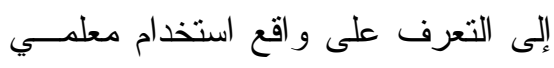
العلوم لإستر اتيجية التقويم البديل وأدو اته

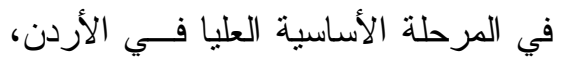

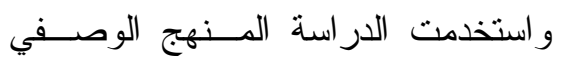
المسحي، وتمثلت أداة الدر اسة في اسبتانة

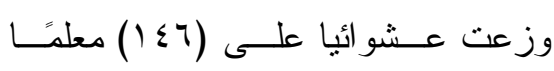
ومعلمة كعينة دراسة وكانت الاســنبانة

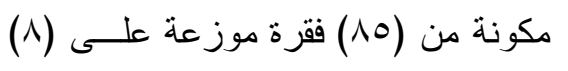




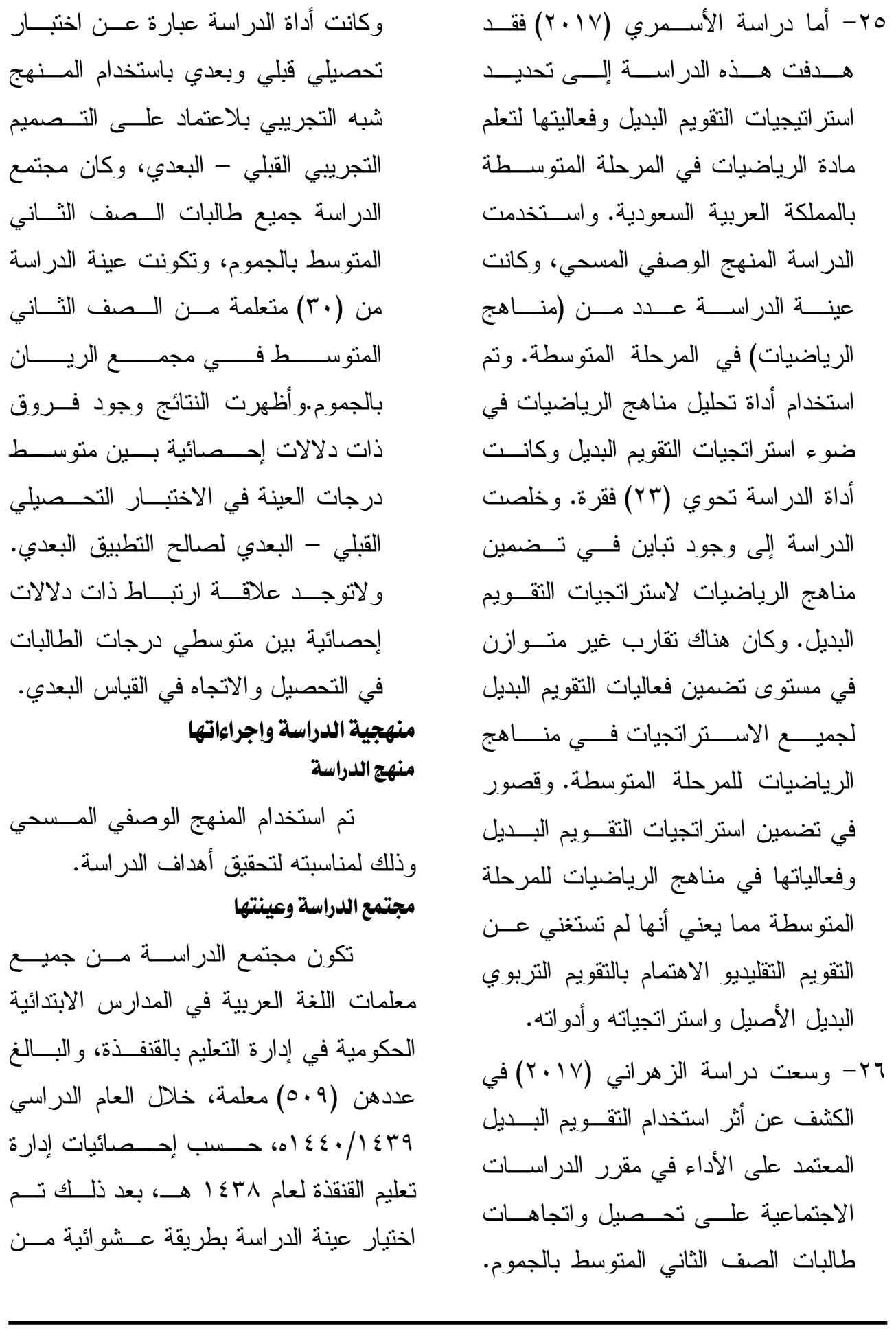


معلمات المرحلة الابتدائية، وبلغ حجم العينة عليهن، وجدول (r) يبين توزيع أفر اد عينــة

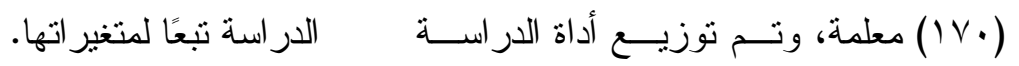

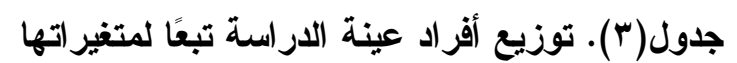

\begin{tabular}{|c|c|c|c|}
\hline النسبة المئوية & العدد & الفئات & المتغير ات \\
\hline$\%$ \% $৭, 々)$ & 0 . & من دورة إلى ثلاثة دور ات & \multirow{4}{*}{ الدور ات التدريبية } \\
\hline$\%$ \%,$\leqslant 1$ & 0 . & من أربع إلى ست دورات & \\
\hline$\% \leq 1,1 \vee$ & $v \cdot$ & V دور ات فأكثر & \\
\hline$\% 1 \ldots$ & 18. & المجموع & \\
\hline$\% 0, r q$ & 9 & أقل من ه & \multirow{4}{*}{ سنو ات الخبرة } \\
\hline$\% \backslash 0, \wedge \wedge$ & rV & من 0- . 1. & \\
\hline$\% \vee \wedge, \wedge$ r & $1 \pi \varepsilon$ & أكثر من - & \\
\hline$\% 1 \ldots$ & iv. & المجموع & \\
\hline$\% 01, \vee 7$ & $\Lambda \Lambda$ & صفوف دنيا & \multirow{3}{*}{ المر احل التدريسية } \\
\hline$\% \leq \Lambda, r \mu$ & NT & صفوف عليا & \\
\hline$\% 1 \ldots$ & 18. & المجموع & \\
\hline
\end{tabular}

النظري و الدراسات الــسابقة ذات العلاقـــة

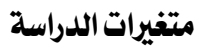

تتاولت الدر اسة المتغير ات الديموغر افيــة بموضوع الدر اسة ومتغير اتها.

وقد أنتبعت الخطو ات الإجر ائية في بنــاء الآتية: - 20 - n - الدور ات التدريبية: لها ثلاثة مسستويات وصياغة الاستبانة كما يلي:

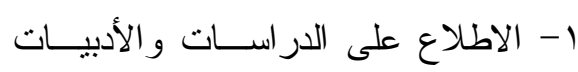
السابقة في التقويم البديل ومنها در اســـة

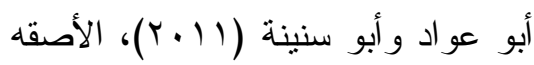

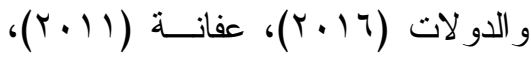

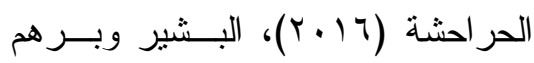

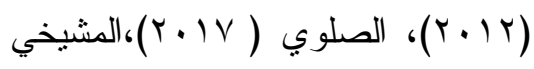

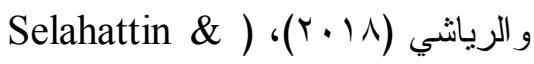
Ozpinar (2010، الحميدي و الظفيري

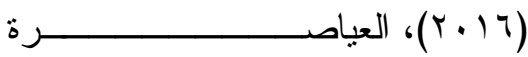
(دورة إلى ثلاث دور ات، من أربعـإلى ست دور ات، 7 دور ات فأكثر).

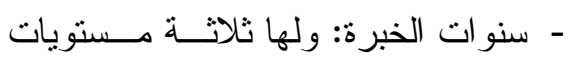
(أقل من 5 سنو ات، من5- 10 سنوات، أكثر من 10 سنو ات).

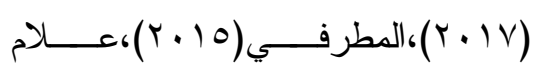
لتحقيق أهداف الدر اسة، فقــــ قامــــ

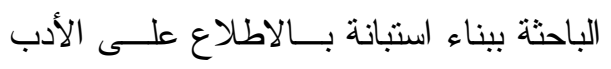


ع - عُرضت الاستبانة علــى عـدد مــن

المحكمين (ملحق: r)، وبعـد التحكـيم

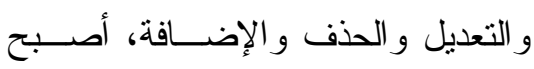

عدد فقرات الاسنبانة (Av) في صورة

نهائية كما هو مبين في الملحــق رقـم فئم

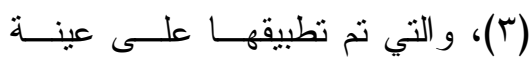

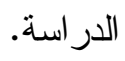

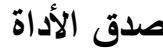

تم التحقق من صدق الأداة وفق الآتي:

أ. الصدق الظاهري(صدق المحكمين)

تم التأكد من الصدق الظاهري لــلأداة

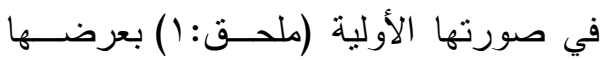

على عدد من المحكمين مــن ذوي الخبــرة

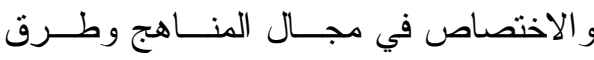

التــدريس بــبعض الجامعـــات الـــسعودية

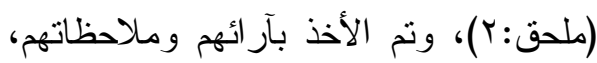

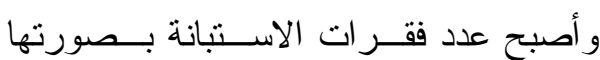

النهائية (^v) فقرة من أصــل (9q) فقــرة

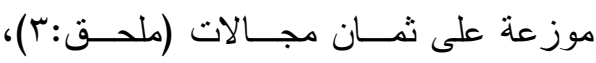

وجــدول (ع) يوضــــ المجــالات وأرقــام

الفقر ات التي تنتع كل مجال.
Sandford\& Hus $)(r \ldots \varepsilon)$

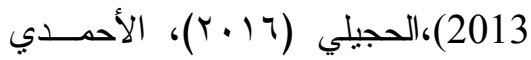

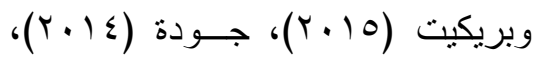

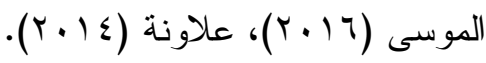

ץ- جمع فقر ات الاستبانة وتحديدها.

r- إعداد الاستبانة في صورتها الأوليــة،

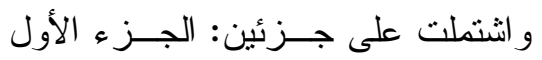

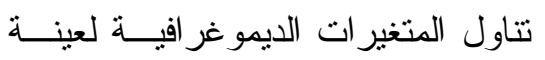

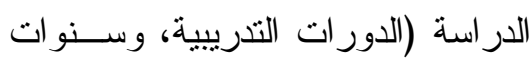

الخبرة، و المر احل التدريسية)، و الجزء

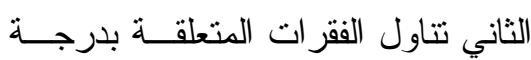

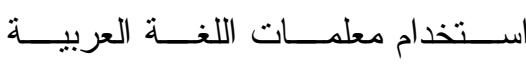

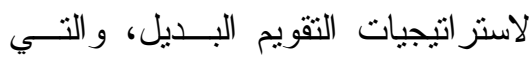

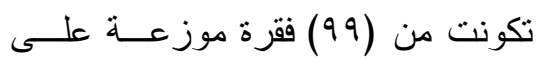

ثمان مجالات كل من التقــويم البــديل

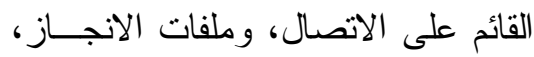

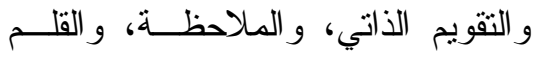

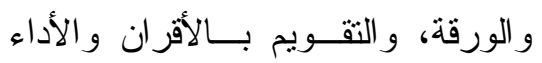

و المقابلة، مدرجة خماسياً حسب مقياس ولاس

ليكرت (كبيرة جدا، كبيرة، متوســطة،

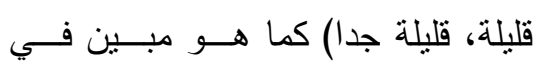

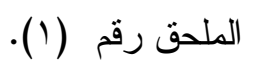


جدول(؛ ) مجالات الاستباتة وعدد الفقرات التابعة لها

\begin{tabular}{|c|c|c|}
\hline عدد الفقرات & المجالات & 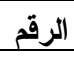 \\
\hline 11 & التقويم البديل القائم على الاتصـل & 1 \\
\hline 11 & التقويم البديل القائم على الإنجاز & r \\
\hline 1. & التقويم البديل القائم على الثقويم الذاتى & $r$ \\
\hline 11 & التقويم البديل القائم على الملاحظة & $\varepsilon$ \\
\hline 11 & التقويم البديل القائم على القلم و الورقة & 0 \\
\hline 1. & التقويم البديل القائم على الأفران & 1 \\
\hline 11 & التقويم البديل القائم على الأداء & $\mathrm{v}$ \\
\hline ir & التقويم البديل القائم على الدقابلة & $\wedge$ \\
\hline$\Lambda V$ & العدد الكلي & \\
\hline
\end{tabular}

مجتمع الدراسة، من خارج عينة الدراســة،

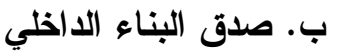

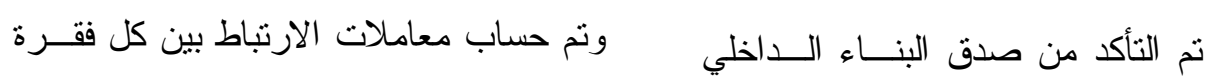

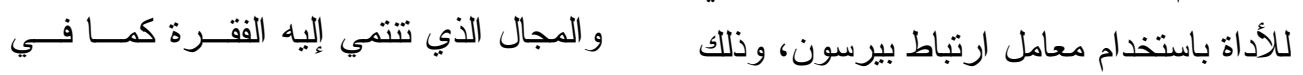

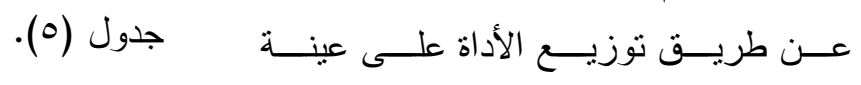

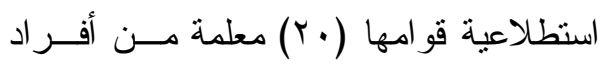

جدول (•). معاملات ارتباط فقرات الأداة مع المجال الأي تنتمي إليه الفقرة

\begin{tabular}{|c|c|c|c|c|c|c|c|c|c|c|c|c|c|c|c|}
\hline \multicolumn{2}{|c|}{ المقابلة } & \multicolumn{2}{|c|}{ الأداء } & \multicolumn{2}{|c|}{ الأقران } & \multicolumn{2}{|c|}{ القلم و الورقة } & \multicolumn{2}{|c|}{ الملاحظة } & \multicolumn{2}{|c|}{ التقويم الذاتي } & \multicolumn{2}{|c|}{ الإنجاز } & \multicolumn{2}{|c|}{ الاتصلال } \\
\hline معامل & c & معامل & r & معامل & r & معامل الارتباط & r & معامل & r & معامل & r & معامل & r & معامل & e \\
\hline$* \cdot, \vee \wedge$ & 1 & ${ }^{*} \cdot, 9 \varepsilon$ & 1 & $* \cdot, 97$ & 1 & ${ }^{*} \cdot, \lambda$ & 1 & $* \cdot 9 \mathrm{~V}$ & 1 & $\cdot \cdot 9 \mathrm{~V}$ & 1 & ${ }^{*} \cdot, 9 \varepsilon$ & 1 & $* \cdot, 9 r$ & 1 \\
\hline$* \cdot, \wedge$ & $r$ & 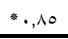 & $r$ & $" \cdot$, , vo & $r$ & $* \cdot, \wedge 9$ & $r$ & $* \cdot \pi$ & $r$ & $* \cdot, 7 \Lambda$ & $r$ & ${ }^{*} \cdot, \wedge$. & $r$ & $" *, 9 r$ & $r$ \\
\hline$" \cdot, \wedge \varepsilon$ & $r$ & $* ., 91$ & $r$ & $" \cdot, 9 £$ & $r$ & $*, T \mathrm{~V}$ & $r$ & $* \cdot, \lambda 1$ & $r$ & $\cdot \cdot, 97$ & $r$ & $" *, \wedge \varepsilon$ & $r$ & $" \cdot, q r$ & $r$ \\
\hline$* \cdot, \wedge r$ & $\varepsilon$ & $*, 9$, & $\varepsilon$ & $* \cdot, \wedge)$ & $\varepsilon$ & ${ }^{*} \cdot, \lambda$ & $\varepsilon$ & $* \cdot 9 \mathrm{~V}$ & $\varepsilon$ & $" \cdot \cdot, \wedge$ & $\varepsilon$ & ${ }^{*} \cdot, \cdot, \cdot$ & $\varepsilon$ & $* \cdot, \wedge)$ & $\varepsilon$ \\
\hline$* ., 00$ & 0 & $" \cdot, \wedge \varepsilon$ & 。 & $*, v_{0}$ & 0 & $* \cdot 9 \pi$ & 0 & $" \cdot \cdot, V 4$ & 0 & $\cdot \cdot, 7 \Lambda$ & 0 & $* \cdot, 09$ & 0 & $*, \pi$ & 0 \\
\hline$* \cdot, 0 r$ & 7 & $\Rightarrow, 9$ & 7 & $* \cdot, \wedge$ & 7 & ${ }^{*} \cdot, \wedge \varepsilon$ & 7 & $* \cdot, \pi$ & 7 & $" \cdot \cdot, v \varepsilon$ & 7 & $* \cdot, 90$ & 7 & $* \cdot, 9 r$ & 7 \\
\hline$* \cdot, V Y$ & v & $*, 9$ & $\mathrm{v}$ & $" \cdot \cdot, \mathrm{AV}$ & $\mathrm{v}$ & ${ }^{*} \cdot, \lambda r$ & v & $* \cdot, \lambda$ & $\mathrm{v}$ & $" \cdot, \wedge 9$ & $\mathrm{v}$ & ${ }^{*} \cdot, \mathrm{V}_{0}$ & v & $* \cdot, 9 r$ & v \\
\hline$* \cdot, 0 Y$ & $\wedge$ & ${ }^{*} \cdot, \mathrm{AA}$ & $\wedge$ & $* \cdot, 97$ & $\wedge$ & $" \cdot, \mathrm{VY}$ & $\wedge$ & $* \cdot 9 r$ & $\wedge$ & ${ }^{*} \cdot, \leqslant \mathrm{V}$ & $\Lambda$ & $* ., 01$ & $\wedge$ & $" \cdot, \vee \vee 9$ & $\wedge$ \\
\hline$* ., 70$ & 9 & $\because, 90$ & 9 & $* \cdot, \vee 9$ & 9 & $* .01$ & 9 & $* \cdot, \lambda$ & 9 & $* \cdot, 17$ & 9 & $* \cdot, 9 r$ & 9 & $" \cdot, 07$ & 9 \\
\hline$* \cdot, 01$ & 1. & $*, 9$ & 1. & $* \cdot, 97$ & 1. & $* \cdot 90$ & 1. & $* \cdot, \lambda$ & 1. & $" \cdot, \wedge 7$ & 1. & $* \cdot, V T$ & 1. & $* \cdot, 9 \leqslant$ & 1. \\
\hline$* \cdot \wedge \wedge$ & 11 & ${ }^{*} \cdot, \mathrm{AV}$ & 11 & & & ${ }^{*} \cdot \lambda, \lambda r$ & 11 & $" \cdot \cdot, \lambda 1$ & 11 & & & $* \cdot, \wedge \mathrm{V}$ & 11 & $* \cdot, 94$ & 11 \\
\hline$" \cdot, \mathrm{VA}$ & ir & & & & & & & & & & & & & & \\
\hline
\end{tabular}

* قيمة "ر" الجدولية عند مستوى(0., . =

تشير النتائج الواردة في جـدول) أن دلالة إحصائية عند مستوى الدلالة (0., .•=

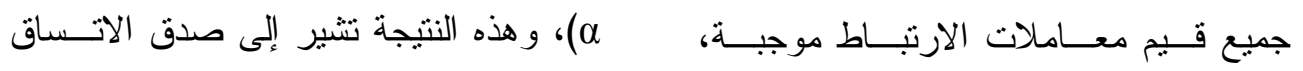

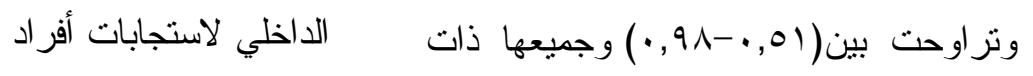


كما تم حساب معامـلـل ارتبــاط كــلـ

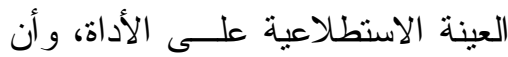

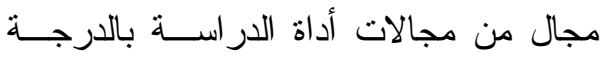

الفقر ات ذات علاقة ارتباطيه دالة إحـصـئياً

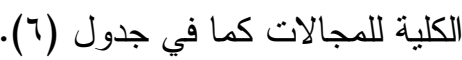

بالمجال الذي تتنمي إليه.

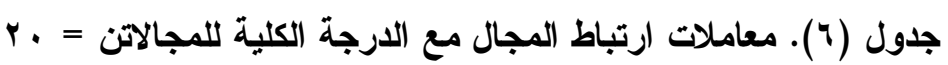

\begin{tabular}{|c|c|c|}
\hline معامل الارتباط & اسم البعد & البعد \\
\hline$*, \wedge 0$ & التقويم البديل القائم على الاتصـال & الأول \\
\hline *,人 & التقويم البديل القائح على الإنجاز & التثاني \\
\hline$*, \leqslant 9$ & التقويم البديل القائع على التقويم الذاتي & 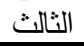 \\
\hline$*, \wedge \mu$ & التقويم البديل القائح على الملاحظة & 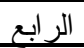 \\
\hline$*, \wedge \leq$ & النتويح البديل القائم على القلم و الورقة & 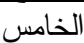 \\
\hline$*, 01$ & التقويح البديل القائر على الأقر ان & السادس \\
\hline$*, \wedge \wedge$ & التقويم البديل القائح على الأداء & 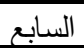 \\
\hline$*, 9 \wedge$ & التثويح البديل القائح على المقابلة & 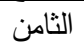 \\
\hline
\end{tabular}

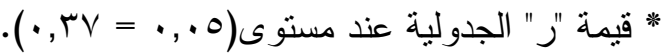

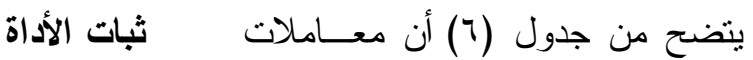

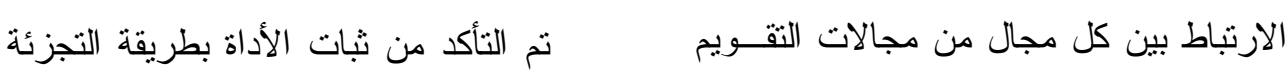

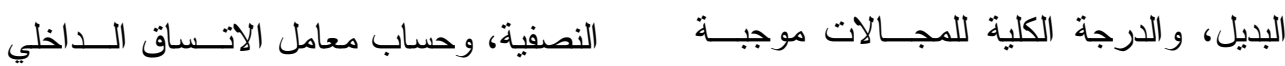

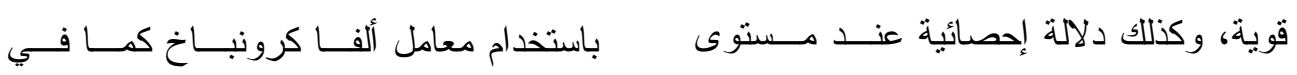

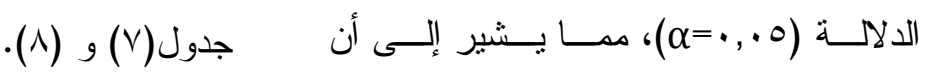

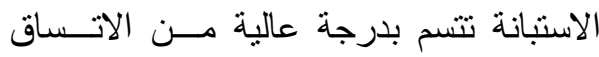

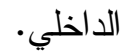

جدول(V). معاملات ثبات أداة الدر اسة

\begin{tabular}{|c|c|c|c|}
\hline ثبات ألفا لكرونباخ & التجزئة النصفية & المجال & الرقم \\
\hline$*, 91$ & $*, 91$ & التقويم البديل القائم على الاتصـال & 1 \\
\hline$*, 94$ & $*, 94$ & التقويم البديل القائم على الإنجاز & r \\
\hline$*, 94$ & $*, 9 \leqslant$ & التقويم البديل القائم على النقويم الذاني & $r$ \\
\hline$*, 9 \leqslant$ & $*, 9 \leqslant$ & التقويم البديل القائر على الملاحظة & $\varepsilon$ \\
\hline$*, 97$ & $*, 97$ & التثقيم البديل القائم على القلم و الورقة & 。 \\
\hline$* ., 99$ & $*, 91$ & التقويم البديل القائم على الأهر ان & 7 \\
\hline$*, 91$ & $*, 9 \Lambda$ & التقويم البديل القائم على الأداء & $\mathrm{v}$ \\
\hline$\because \cdot 9 \mathrm{Y}$ & $*, 91$ & النتويم البديل القائم على الدقابلة & $\Lambda$ \\
\hline$*, 99$ & $\because, 9 \Lambda$ & الثبات الكلي للاستبانة & 9 \\
\hline
\end{tabular}

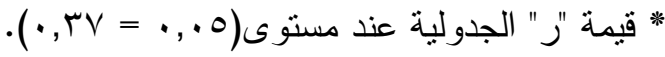

०\&. 


$$
\text { r - تحديد مجتمع الدر اسة و عينتها. }
$$
r - توزيع أداة الدراسة على أفر اد العينة. ـ - جمع البيانات و المعلومات من أفــر اد

$$
\text { العينة. }
$$

0- تحليل البيانـات باســتخدام الرزمـــة

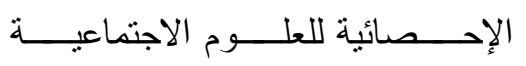

.(SPSS)

1 - مناقثة نتائج الدر اسة وتقسير ها وفق

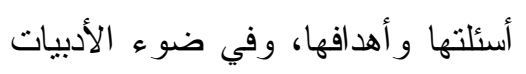

$$
\text { و الدر اسات السابقة. }
$$

\section{نتائج الدراسة ومناقشتها وتفسيرها}

أولًا: تتائج السؤال الأول ومناقشتها وتفسيرهائها

ونص علـى : مــا درجــة اســتخدام

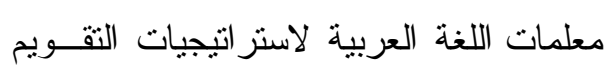

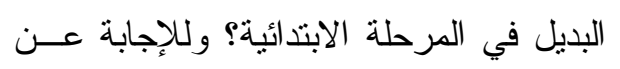
هذا السؤال نتّ حساب المتوسطات الحسابية،

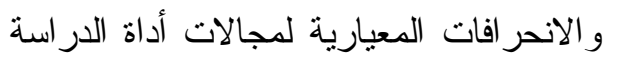

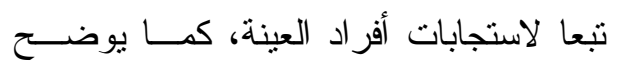

جدول (^). (يعا لانيجابات
تشير النتائج في جدول (V) أن معامل

الثبات بطريقة ألفا كرونباخ انحـصر بـــين

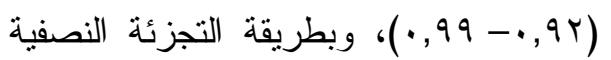

كان بين (19,9 . - 9^, • •)،و هي قيمة الدلالة

إحــصائيا، ومناســبة لاســتخدام الاســنبانة

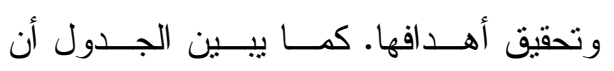

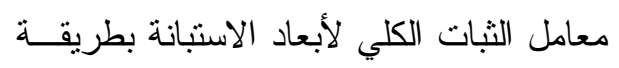

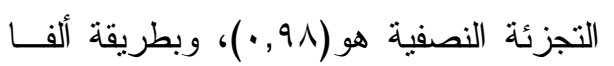

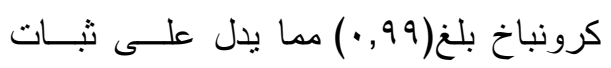

إجرايوات تطبيق الدراسة :

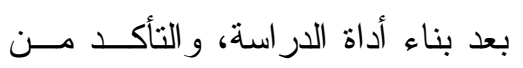

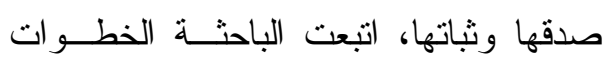
التالية في تطبيق الدراسة:

1- الحصول على خطاب تشهيل المهــــة

من إدارة الجامعة موجـــه إلــى إدارة

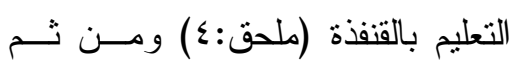

الحصول على خطاب من إدارة تعليم

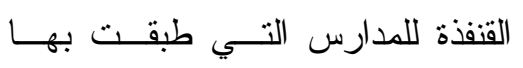

$$
\text { الدر اسة (ملحق:0). }
$$




\section{جدول (^). المتوسطات الحسابية والاحمر افات المعيارية لمجالات أداة}

الار اسة حسب متوسطاتها الحسابية

\begin{tabular}{|c|c|c|c|c|c|}
\hline لدرجة & 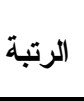 & الالحر افات & الحستبي & الأبعاد & 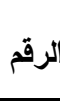 \\
\hline كبيرة & $\varepsilon$ & $\cdot, V Y$ & $r, q 1$ & التقويم البديل القائم على الاتصـال & 1 \\
\hline كبيرة & $\varepsilon$ & $\cdot, 1 \wedge$ & r, qv & التقويم البديل القائم على الإنجاز & r \\
\hline كبيرة & $\varepsilon$ & $\cdot, 1$. & r, ( & التقويم البديل القائم على التقويم الذاتي & $r$ \\
\hline كبيرة & $\varepsilon$ &., 19 & $r, 97$ & التقويم البديل القائم على الملاحظة & $\varepsilon$ \\
\hline كبيرة جداً & 0 &., 10 & $\varepsilon, r$ r & التقويم البديل القائم على القلم و الورقة & 0 \\
\hline 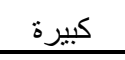 & $\varepsilon$ &., 11 & ५, १9 & التقويم البديل القائم على الأفران & 7 \\
\hline 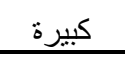 & $\varepsilon$ & $\cdot, 17$ & $\varepsilon, \cdot 1$ & التقويم البديل القائم على الأداء & $\checkmark$ \\
\hline كبيرة - كيرة & $\varepsilon$ & $\cdot, 1 \mathrm{H}$ & $\varepsilon, \cdot r$ & التقويم البديل القائم على المقابلة & $\wedge$ \\
\hline كبيرة & $\varepsilon$ & $\cdot, 11$ & $r, 99$ & الارجة الكلية & \\
\hline
\end{tabular}

في إكساب المعلمات مهار ات ومبادئ التقويم

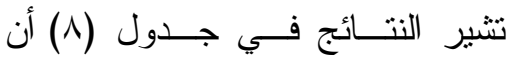

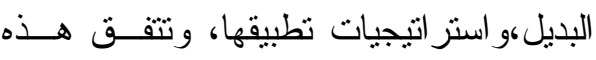

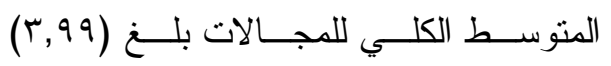

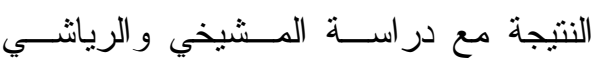

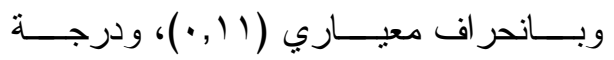

(Y.11)

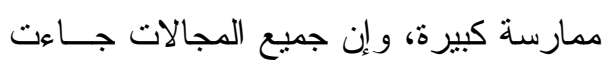

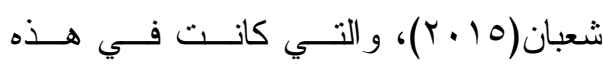

بدرجة كبيرة وتز اوحت متوسطاتها الحسابية

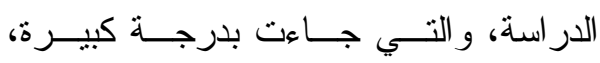

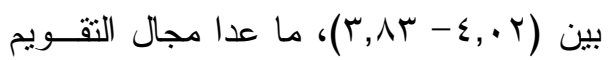

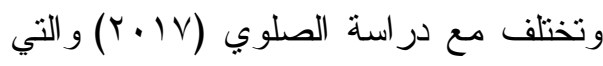

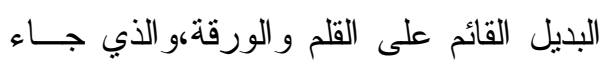

كانت الدرجة الكلية لاستخدام أساليب التقويم

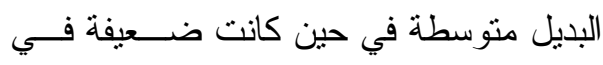

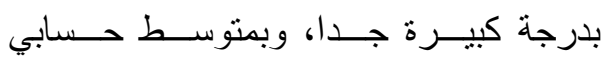

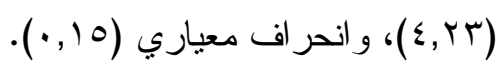

ممارسة معلمي العلوم لمجال التقويم بالأقران

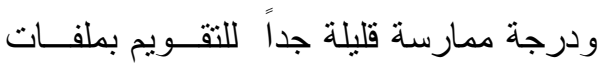

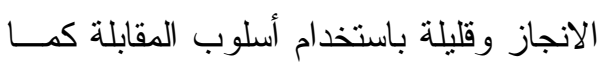

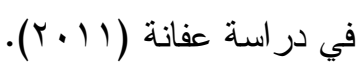

وقد تعزى هذه النتيجة إلى ما تبذلـــــ

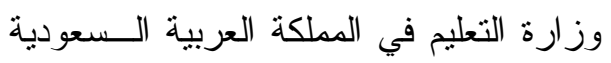

من جهد في تقديم بر امج تعليميـــة تجديديـــة

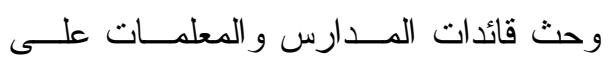
وجاء في المرنبة الأولى مجال التقويم

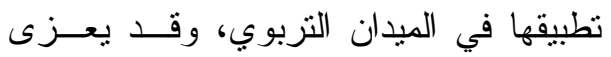

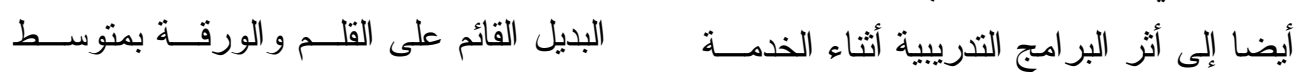


وجاء في المرتبـــة الأخيــرة مجـــال

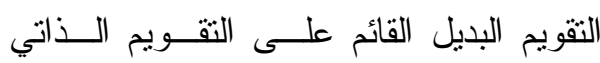

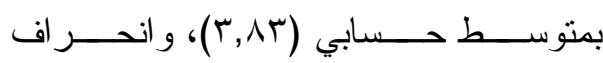
معياري(· • (.) )، و على الرغم من أنه جـاء

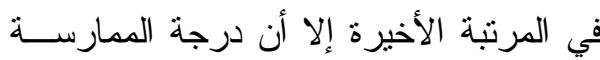

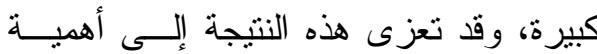

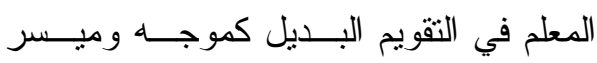
لعملية التعلم؛ حيث أن دوره يتمنل في إعداد

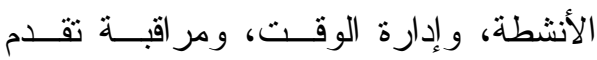

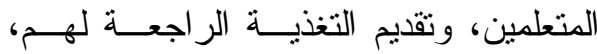
وتوجيه8ه، و أن دوره لم يعد ملقناً للمعرفــة،

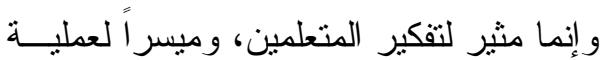

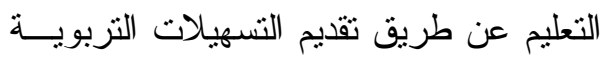
المناسبة للمتعلمين، وتتفق هذه النتيجـــة مـــع

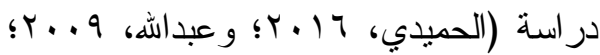

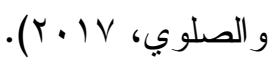

ولمزيد من التفصيل لبقية المجــالات

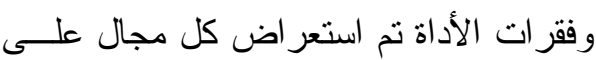
حدة كما يلي: أ.التقويم البديل القائم على الاتصال تم حسـاب المتوســطات الحسـابية

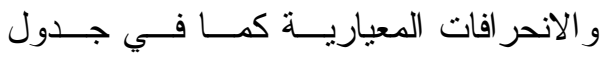

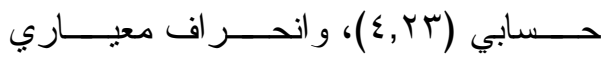

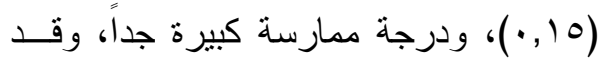
يعزى ذلك إلى أن اســتر اتيجيات ومبـــادئ

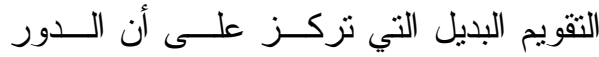
الرئيسي للمتعلم وليس المعلم، وأن المــتعلم هو محور العملية التعليمية التعلمية، ولم يعد دوره دور المتلقي السلبي، وأن التقويم البديل

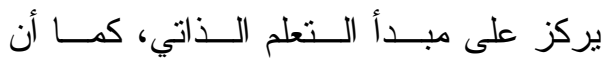

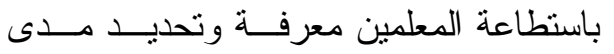
ماحققوه من أهـــداف لغويـــة فـــي المــــهج

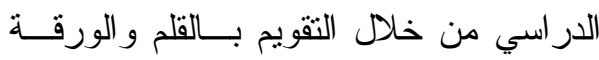

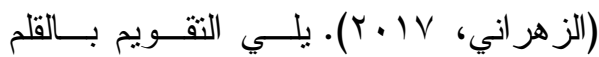

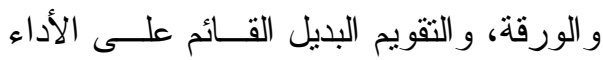
بمتوسط حسابي (1 . ,ـ) و انحر اف معيـاري

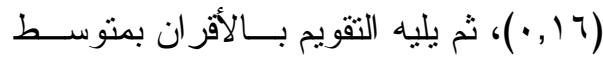

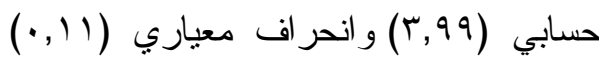
، ثم يليه الثقويم البديل القائم علــى ملفــات

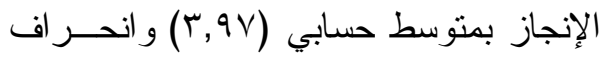

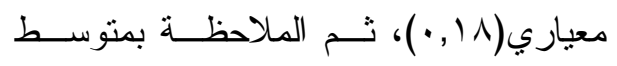
حسابي (7,97) و انحر اف معياري (9 (1, , )، ثم التقويم البديل القائم على الاتصال بمتوسط

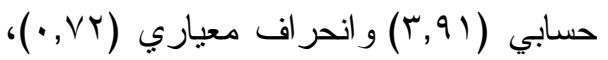

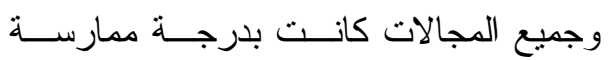
كبيرة. - مبر. 
جدول(9). المتوسطات الحسابية والاتحر افات المعيارية لمجال التقويم البديل القائم على الاتصال حسب متوسطاتها الحسابية

\begin{tabular}{|c|c|c|c|c|c|}
\hline الارجة & 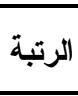 & الالمعر افياري & الحستوسطي & الفقر ات & 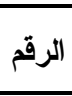 \\
\hline كبيرة & $\varepsilon$ & $\cdot, \wedge 9$ & $r, 70$ & أحسد اهن للطالبات الهدف من استخدام الاتصـال لتقويم & 1 \\
\hline كبيرة & $\varepsilon$ & $\cdot, \wedge \uparrow$ & r,q & مستو الهن اللغويلة الاتصال المناسبة للطالبات عند تقييم & r \\
\hline كبيرة & $\varepsilon$ & $\cdot, \vee \vee 9$ & $\varepsilon, \cdot 9$ & 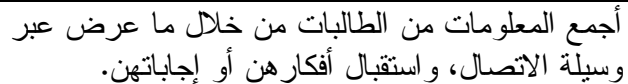 & $r$ \\
\hline كبيرة & $\varepsilon$ & $\cdot, \wedge r$ & $r, q$. & أثنجع الطالبات على تقويم المستوى اللغوي لبعضهن. & $\varepsilon$ \\
\hline كبيرة جداً & 0 & $\cdot, \vee_{0}$ & $\varepsilon, Y$. & ألظة ح أسئلة محددة الهُف، ومرنبطة مباتشرة بدروس & 0 \\
\hline كبيرة & $\varepsilon$ & $\cdot, \wedge \wedge$ & $\varepsilon, .0$ & أعطي الطالبات زمنأ كافياً لعرض أفكار هن و إجاباتهن. & 7 \\
\hline كبيرة & $\varepsilon$ & $\cdot, 9 \vee$ & ऍ,人 & و الميسار ات المستوى اللغوية المتعمة. & V \\
\hline كبيرة & $\varepsilon$ & $\cdot, 99$ & r, $\tau \varepsilon$ & 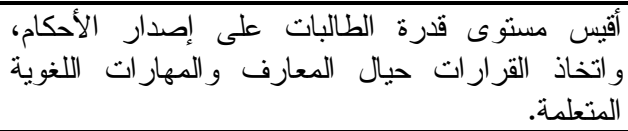 & $\wedge$ \\
\hline كبيرة & $\varepsilon$ & $\cdot, \wedge \vee$ & $r, \wedge$. & تقييمهن عن طقريق الطالتبات في تعلم اللغة العربية من خلال & 9 \\
\hline كبيرة & $\varepsilon$ & $\cdot, \wedge \varepsilon$ & $r, 90$ & ألنخة العربية. احتياجات الطالبات اللغوية لتحقيق أهداف تعلم & 1. \\
\hline كبيرة & $\varepsilon$ & $\cdot, 10$ & $\varepsilon,+1$ & أقدم للطالبات التغذية الر اجعة حول مستو اهن اللغوي. & 11 \\
\hline \multicolumn{2}{|c|}{ 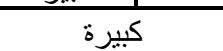 } & $\cdot, 1 \mathrm{~V}$ & $r, 94$ & الارجة الكلية & \\
\hline
\end{tabular}

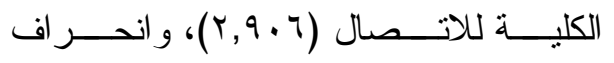

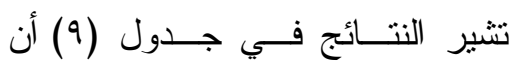

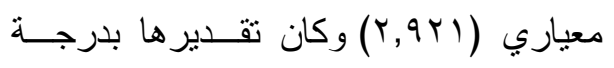

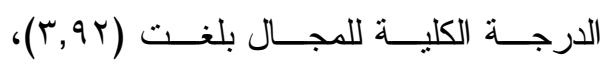

منوسطة.

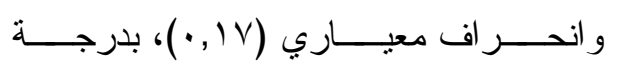

وقد جاءت الفقرة (0) فـــي المرتبــة

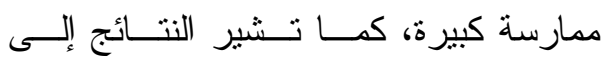

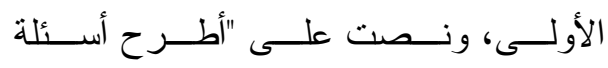

أن فقرة و احدة جاء تقدير ها بدرجـــة كبيــرة

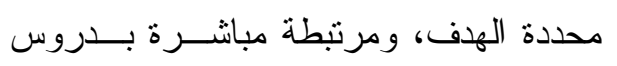

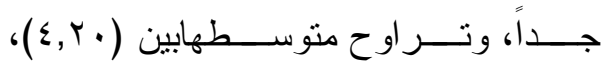

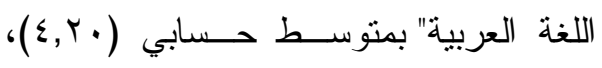

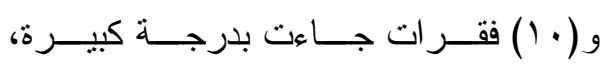

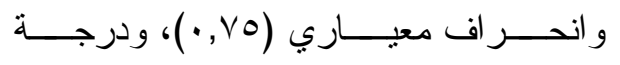

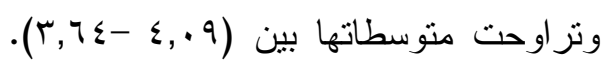

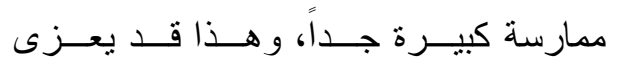

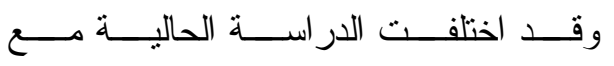

إلىى إدراك معلمات اللغـــة العربيــة لقيمـــة

در اسة (عبداله، 9 . . . حيث كانت الدرجة 
القر ار ات حيال المعارف و المهار ات اللغويـــة

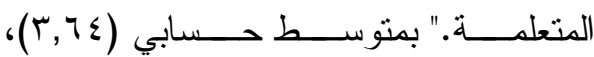

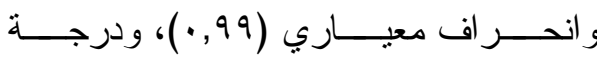
ممارسة كبيرة. وعلــى الــرغم مــن أنـــه

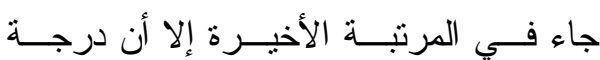

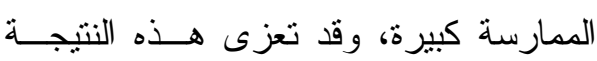

إلى أهمية المعلم في التقويم البديل كموجـهـ

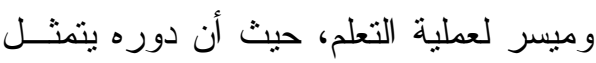

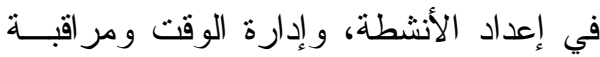

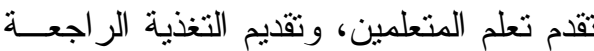

وتوجيهمح.

ب.التقويم البديل القائم على الإججاز

تم حـساب المتوســـات الحسـسابية

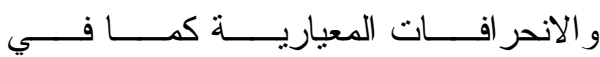

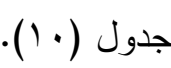

طرح أسئلة محددة الهدف وتكون مرتبطـــة

بالدرس، وبالتــالي يكــون هنــالك إيجابيـــة

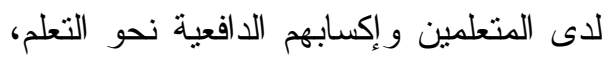
و هي مهارة تحديد الهدف.

وجاءت الفقرة (ץ) في المرنبة الثانية

و التي نصها "أجمع المعلومات من الطالبــات

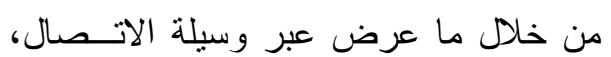

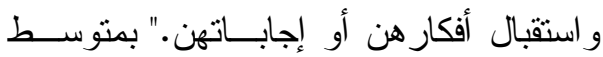

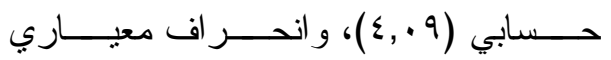

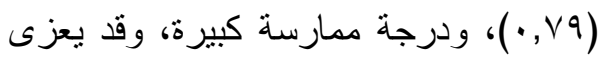
ذللك إلى جمع المعلومــات مــن الطالبــات ودرهات و استقبال أفكار هن تعتبر مهارة من المهارات

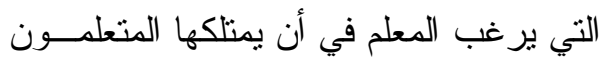
في حياتهم، وجاء في المرتبة الأخيرة الفقرة

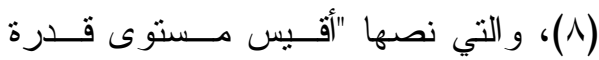
الطالبات على إصـــدار الأحكــام، و اتخــاذ 


\begin{tabular}{|c|c|c|c|c|c|}
\hline \multicolumn{6}{|c|}{ جدل( · 1) المتوسطات الحسابية والاتحر افات المعيارية لمجال التقويم البديل القائم } \\
\hline الارجة & الرتبة & الالمعر اف المياري & الحتوسط & 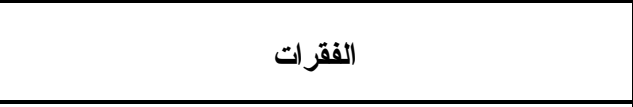 & 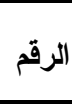 \\
\hline كبيرة & $\varepsilon$ & 1 & ґ,^৭ & 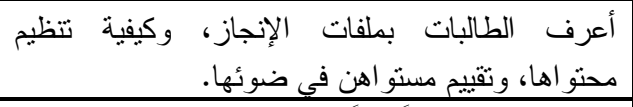 & 1 \\
\hline كبيرة & $\varepsilon$ & $\cdot, 9 \wedge$ & $\curlyvee, \wedge \varepsilon$ & 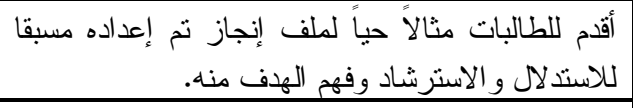 & r \\
\hline كبيرة & $\varepsilon$ & $\cdot, 94$ & $\varepsilon, \cdot 9$ & أشجع الطالبات على إعداد ونتظيم ملفات الإنجاز . & r \\
\hline كبيرة & 0 & $\cdot, \vee \vee$ & $\varepsilon, Y_{\uparrow}$ & بوضوح أوجالبات إلى كتابة بياناتهن على ملفات الإنجاز & $\varepsilon$ \\
\hline كبيرة & $\varepsilon$ & $\cdot, 94$ & $\varepsilon, 1 \varepsilon$ & أشجع الطالبات على تفعيل ملفات الإنجاز بالصورة & 0 \\
\hline كبيرة & $\varepsilon$ & $\cdot, \wedge \uparrow$ & $\varepsilon, \cdot 7$ & 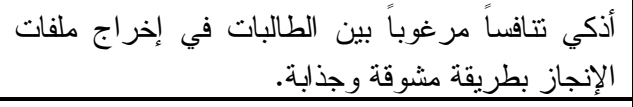 & 7 \\
\hline كبيرة & $\varepsilon$ & $\cdot, \wedge \mu$ & $\varepsilon, .0$ & 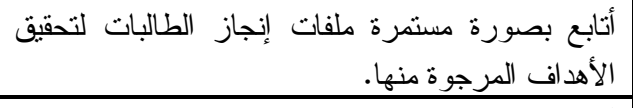 & V \\
\hline كبيرة & $\varepsilon$ & $\cdot, \wedge \wedge$ & $\varepsilon, 11$ & 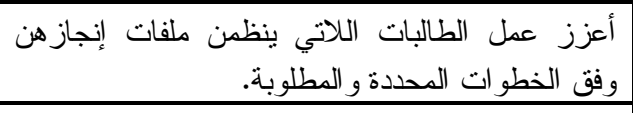 & $\wedge$ \\
\hline كبيرة & $\varepsilon$ & $\cdot, 99$ & $r, v \varepsilon$ & أنجاز اتهزن الطالبات للمشاركة في معارض المدرسة بملفات & 9 \\
\hline كبيرة & $\varepsilon$ & $\cdot, 91$ & $r, \wedge \Lambda$ & 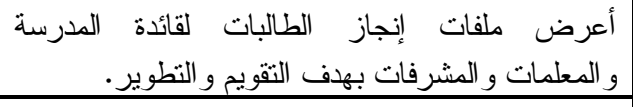 & $1 \cdot$ \\
\hline كبيرة & $\varepsilon$ & 1 & $r, \wedge т$ & ملف الإنجاز أولياء الأمور على أجود أعمال بناتهن من خلا & 11 \\
\hline كبيرة & $\varepsilon$ & 1,01 & $r, 99$ & الارجة الكلية & \\
\hline
\end{tabular}

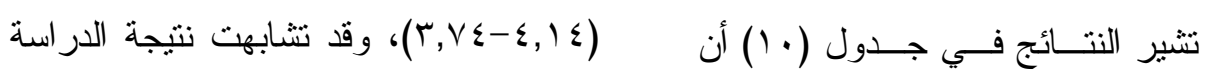

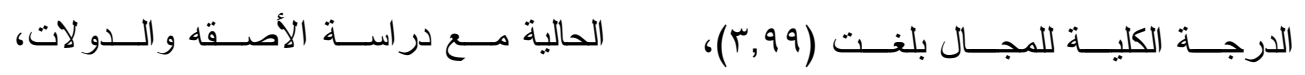

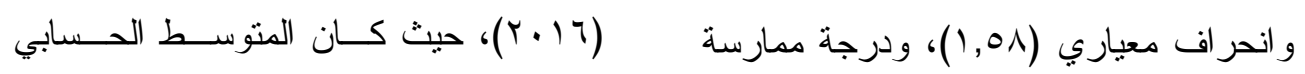

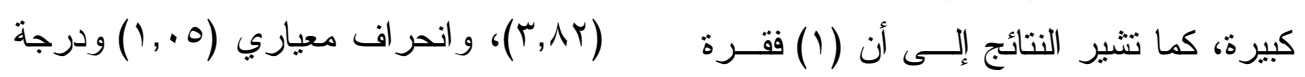

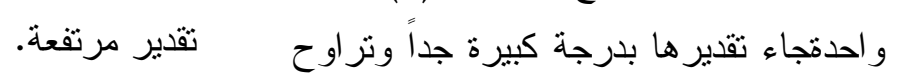

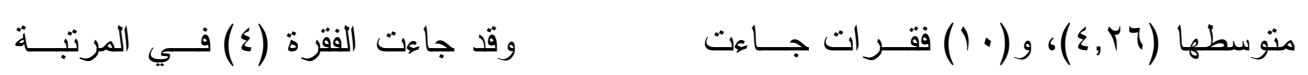

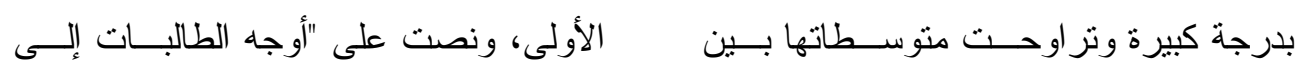


(99, (·)، ودرجة ممارسة كبيــرة. وعلـى

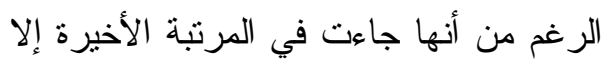

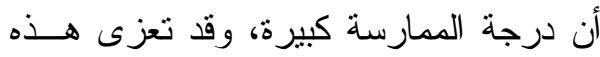

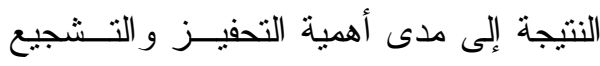

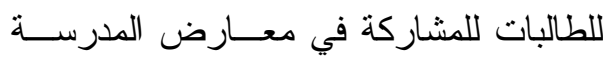
بملفات إنجاز اتهن، و هذا يكون بالطبع له أثز

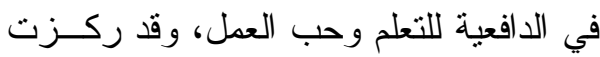
بعض الدراسات السابقة علــى اســتر اتيجية ملف الاتجاز دون غيرهـــن اســنز اتيجيات

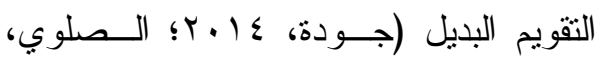

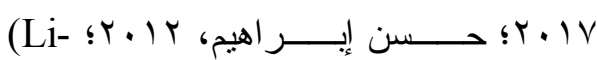

.Ching, 2016 ج.التقويم البــديل القــائم علـــى التقــويم الأني تم حـساب المتوســـات الحـسـابية

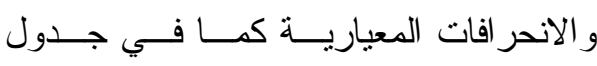

كتابة بياناتهن على ملفات الإنجاز بوضوح." بمتوسط حسابي († Y, \&)، و انحر اف معياري

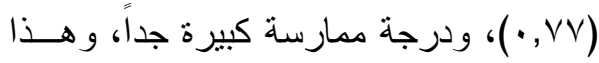

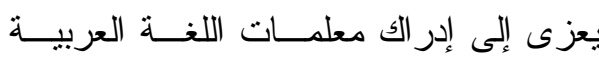

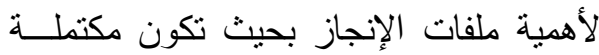

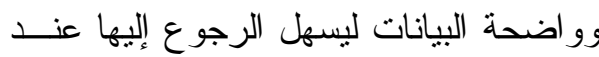
الحاجة لها. وجاءت الفقرة (0) في المرتبة الثانية و التي نصها "أثنجع الطالبات علــى تفعيـلـل ملفات الإنجاز بالصورة المطلوبة." بمتوسط

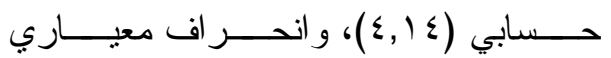
(r ( 9, ·)، ودرجة ممارسة كبيرة، وقد يعزى

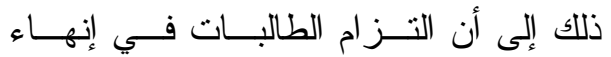
المهمات المطلوبة منهم تعتبر مهـارة مسنـ المهارات التي تزغب المعلمة في أن تمنلكها الطالبات في حياتهن، وهي مهــارة تحديــد الهدف بفاعلية.

وجاء في المرنبة الأخيرة الفقرة (9)،

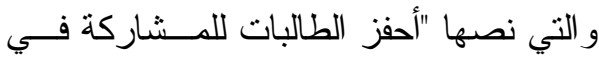
معارض المدرســــة بملفــات إنجـــاز اتهن." بمتوسط حسابي (Y,V (Y.V)، و انحر اف معياري 


\section{جدول(11)}

المتوسطات الحسابية والاتحر افات المعيارية لمجال التقويم البديل

القائم على التقويم الأتي حسب متوسطاتها الحسابية

\begin{tabular}{|c|c|c|c|c|c|}
\hline الارجة & 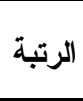 & الالمعراف & المستوسط & الفقرات & 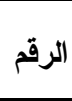 \\
\hline كبيرة & $\varepsilon$ & $\cdot, \wedge)$ & r,vo & ألثنجع الطالبات على التقييم الـــــي لــتعلمهن & 1 \\
\hline 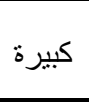 & $\varepsilon$ & $\cdot, \mathrm{V} \varepsilon$ & ץ, १५ & 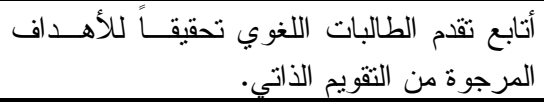 & $r$ \\
\hline كبيرة & $\varepsilon$ & $\cdot, \vee \vee \top$ & $r, q \leq$ & أدرب الطالبات على تقبل النقد الهادف البناء. & r \\
\hline 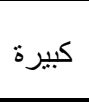 & $\varepsilon$ & $\cdot, \wedge$. & r,^q & لهنابع تقبل الطالبات لنقد أنفسهن، ونقد الآخرين & $\varepsilon$ \\
\hline كبيرة & $\varepsilon$ & $\cdot, 9$. & r,१० & أطر ح اختبار ات ذاتية على الطالبــات تقــيس & 0 \\
\hline كبيرة & $\varepsilon$ & $\cdot, 94$ & r,マ^ & 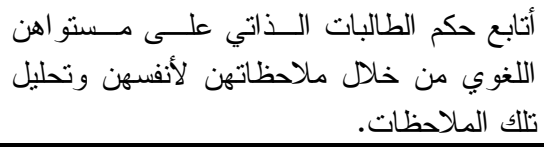 & 1 \\
\hline كبيرة & $\varepsilon$ & $\cdot, \wedge 0$ & $r, q$. & أعزز نقاط القوة في تعلم الطالبات اللغوي بناءً & V \\
\hline 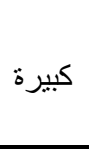 & $\varepsilon$ & $\cdot, 9 \wedge$ & $r, V r$ & 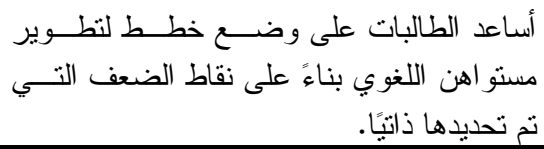 & $\wedge$ \\
\hline كبيرة & $\varepsilon$ & $\cdot, 94$ & 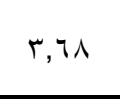 & 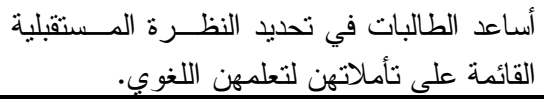 & 9 \\
\hline 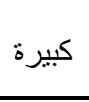 & $\varepsilon$ & $\cdot, 97$ & $r, \wedge 0$ & 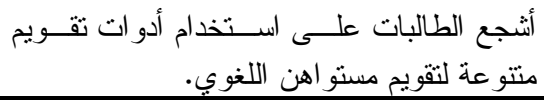 & 1. \\
\hline كبيرة & $\varepsilon$ & $1, \cdot r$ & $\longleftrightarrow, \wedge \varepsilon$ & الارجة الكلية & \\
\hline
\end{tabular}

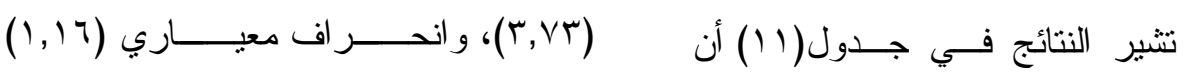

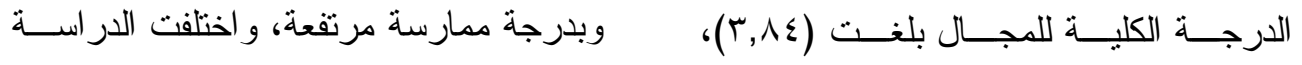

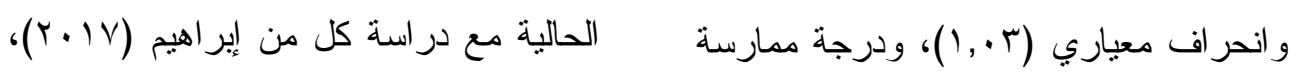

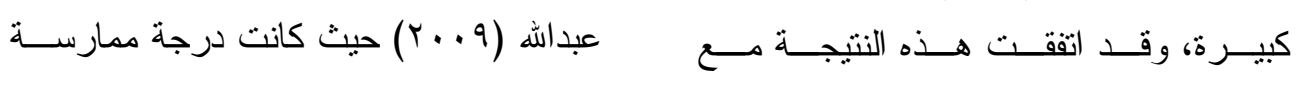

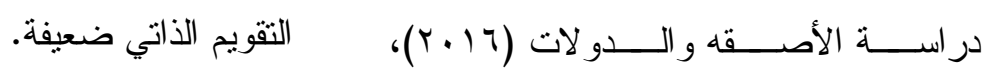

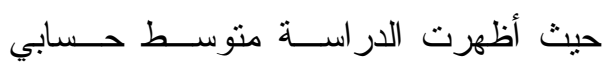


دور كبيــر فـي قيــاس وتقــويم تحــصيل

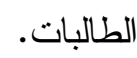

وجاء في المرنبة الأخيرة الفقرة (9)،

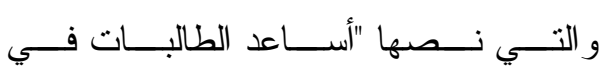

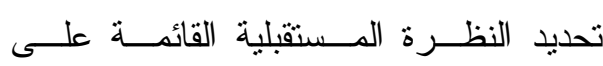

تأملاتهن لتعلمهن اللغوي." بمتوسط حسـسابي

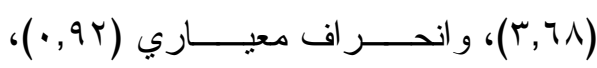

ودرجة ممارسة كبيرة، وعلى الرغم من أنها

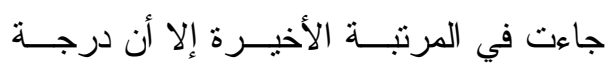

الممارسة كبيرة، وقد تعزى هذه النتيجة إلى الى

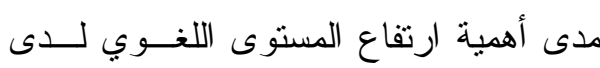

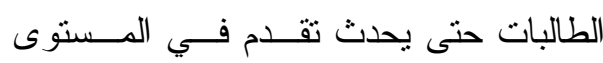

اللغوي للطالبات ولما لــذلك مــن دور فـي تهي

تحسين العملية التعليمية و الارتقاء بمسستوى ولمي دوري

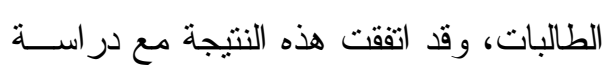

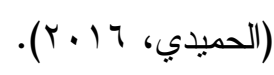

د.التقويم البديل القائم على الملاحظة

نم حــساب المتوســطات الحـسابية

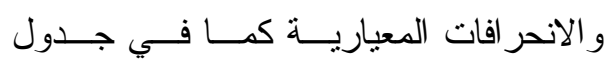

(I)
كما نتير النتائج إلى أن( • () فقرات

جاءت بدرجة كبيرة، وتر اوحت متوســطاتها

بين (ד, (

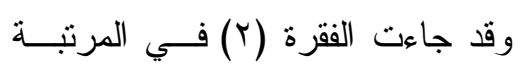

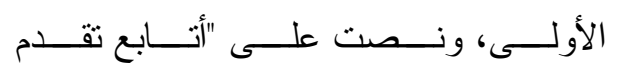

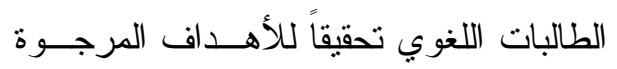

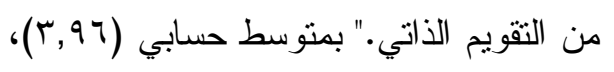

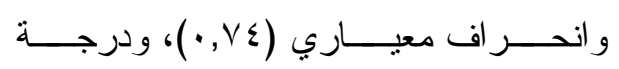

ممارسة كبيرة، وهــذا يعـزى إلـى إدر الك

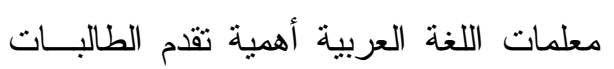
في المستوى اللغوي لما لـــللك مسـن نـأثير

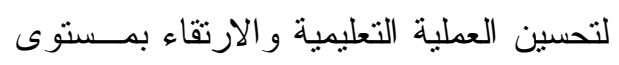
الطالبات.

وجــاءت الفقــرة (0) فـــي المرتبــة

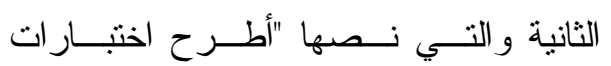
ذاتية على الطالبات تقيس مستو اهن اللغــوي

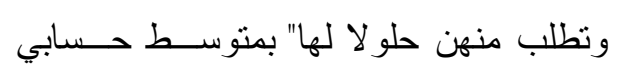

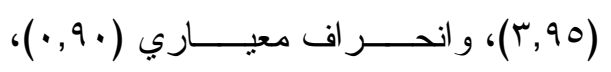

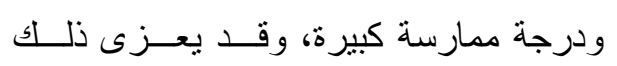

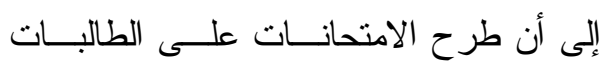
يكون له أثز في تحسين مـسـتو اهن اللغــوي

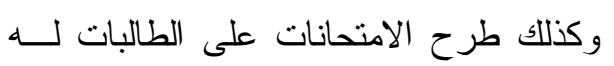




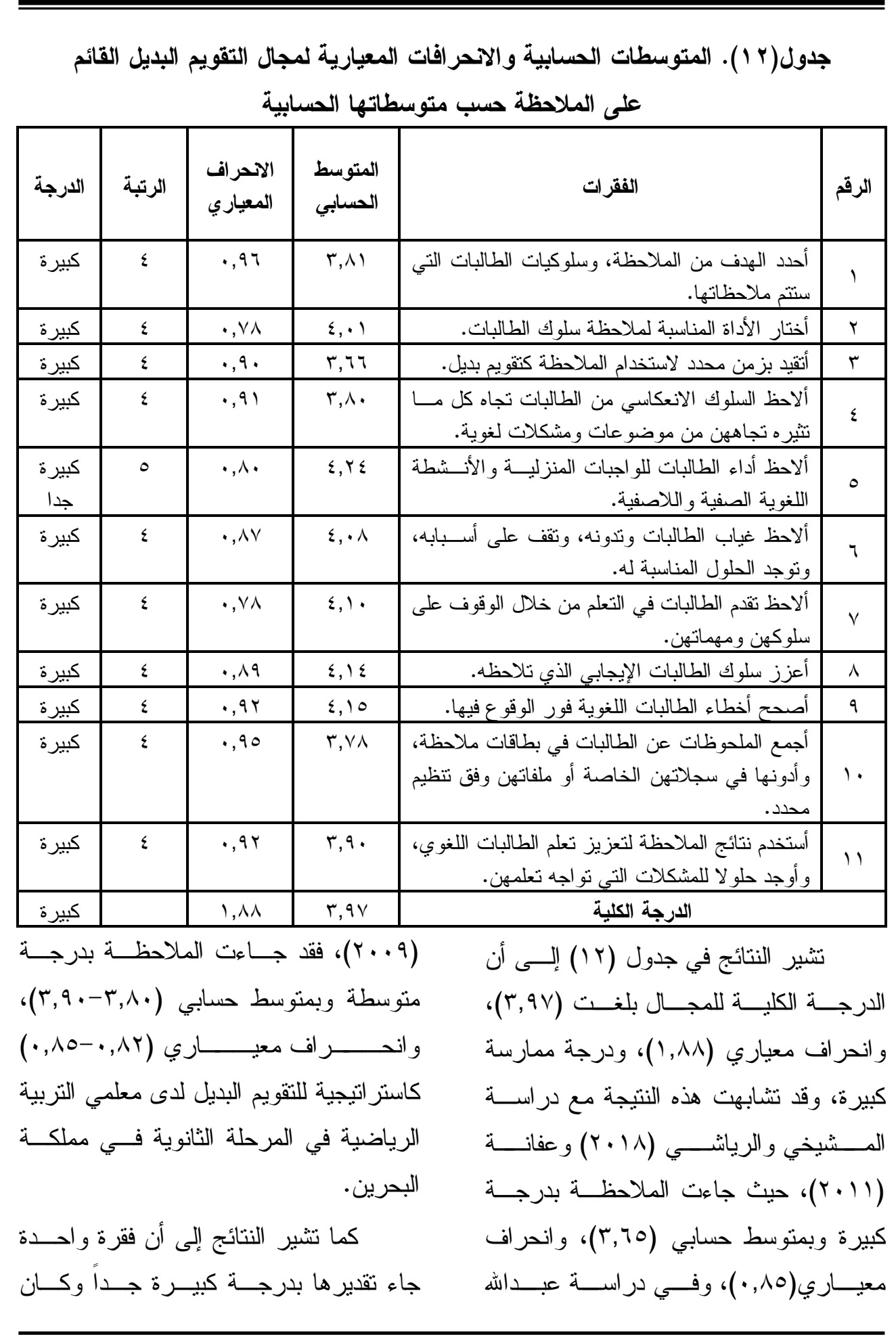


وجاء في المرنبة الأخيرة الفقرة (r)، و التي نصها "أتقيد بزمن محسـدد لاســتخدام

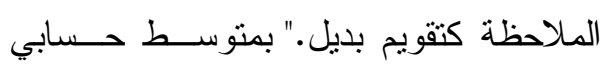

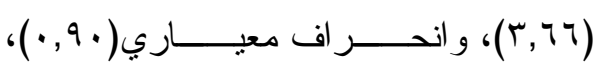

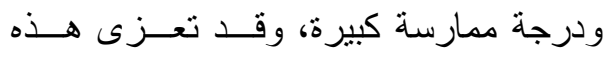

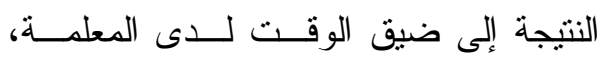
وطول المقرر الدراسي وضـــرورة إنهائــه،

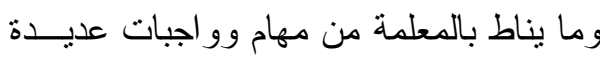

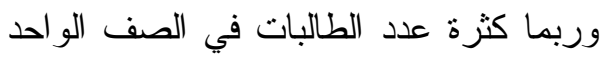

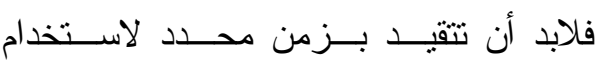

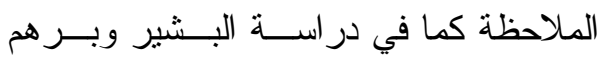

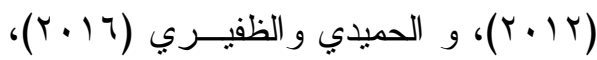

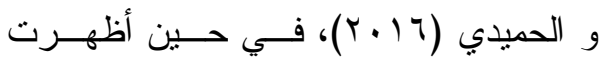

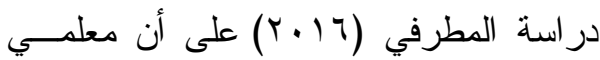
العلوم الثرعية في المرحلة الثانوية حرصوا

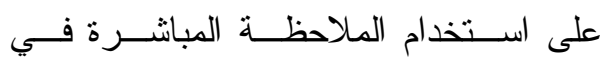

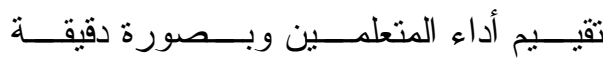

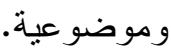

التقويم البديل القائم على القلم والورقة نم حسـاب المتوســـات الحــسابية و الانحر افات المعيارية كما في الجدول(r ا ).

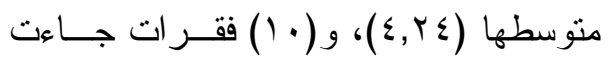
بدرجة كبيرة وتر اوحــت منوســـاتها بــين

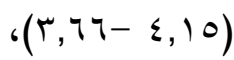
وقد جاءت الفقرة (0) فـــي المرتبــة الأولى، ونصت على "ألاحظ أداء الطالبــات

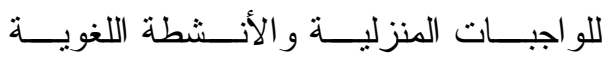

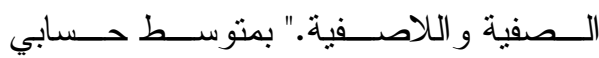

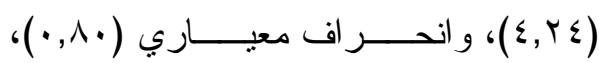

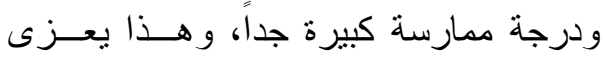
إلى إدر الك المعلمات لأهمية أداء الواجبـــات ولهات

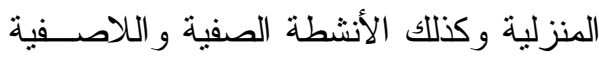
لأن التقويم البديل يتطلــبـ مــن الطالبــات تطبيق معارفهن ومهارتهن ودمجها لإنجــاز المهمة. وجاءت الفقرة (9) في المرنبة الثانية و التي نصها "أصحح أخطاء الطالبات اللغوية فور الوقوع فيها" بمتوسط حسسابي (10, ؟ )، و انحر اف معياري (rو, •))، ودرجة ممارسة كبيرة، وقد يعزى ذلك إلى أن كثرة الأخطاء

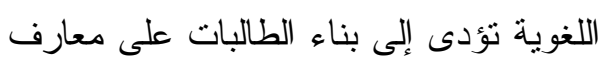
ومعلومات خاطئة فلابد من تصحيح الأخطاء اللغوية فور وقوعها. 


\begin{tabular}{|c|c|c|c|c|c|}
\hline \multicolumn{6}{|c|}{ جدول(r ا ). المتوسطات الحسابية والاتحر افات المعيارية لمجال التقويم البديل القائم } \\
\hline الارجة & الرتبة & المعياري & 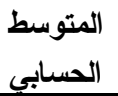 & 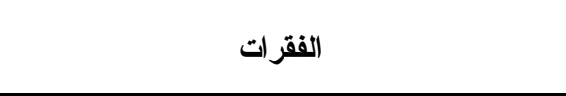 & 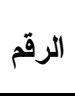 \\
\hline كبيرة جداً & 0 & $\cdot, \wedge \varepsilon$ & $\varepsilon, Y$. & أختبر الطالبات كتابيا لقياس أهداف محددة فــي & 1 \\
\hline كبيرة جداً & 0 & $\cdot, \mathrm{V}_{0}$ & $\varepsilon, r_{0}$ & أختبر الطالبات كتابيا لقياس مهار اتهن اللغوية. & $r$ \\
\hline كبيرة جداً & 0 & -, yo & $\varepsilon, \varepsilon r$ & واضصوغ وأسئلة الاختبار ات التحريريــة صـــاغة & $r$ \\
\hline كبيرة جداً & 0 & $\cdot, V \varepsilon$ & $\varepsilon, \varepsilon 0$ & لنقبيم مستوى الطئلة الاختبار اتلنوي. التحريرية المستخدمة & $\varepsilon$ \\
\hline 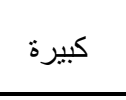 & $\varepsilon$ & $\cdot, 9 \vee$ & $r, \wedge \Lambda$ & أنستخدم جدول المو اصــفات لبنــاء الاختبـــارات & 0 \\
\hline كبيرة جدا & 0 & $\cdot, \wedge 1$ & $\{, r)$ & أنتخريرية. & 7 \\
\hline كبيرة جداً & 0 & $\cdot, \wedge \varepsilon$ & $\varepsilon, \uparrow \wedge$ & محدد. أصحح إجابات الطالبات بناءٌ على نموذج إجابة & V \\
\hline كبيرة & $\varepsilon$ & $\cdot, \mathrm{V}$ & $\varepsilon, 11$ & على مستوى الطالبات اللغوي. ألتحريرية لإصدار حكـــ & $\wedge$ \\
\hline كبيرة جداً & 0 & $\cdot, V r$ & $\varepsilon, Y^{\prime}$ & 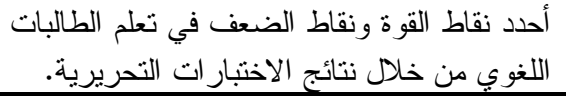 & 9 \\
\hline كبيرة & $\varepsilon$ & $\cdot, 9 \cdot$ & $\varepsilon, 1 V$ & 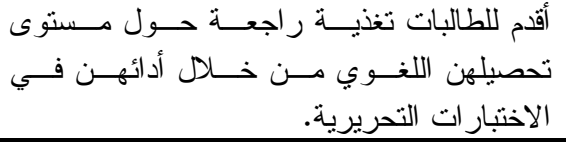 & 1. \\
\hline كبيرة جدا & 0 & $\cdot, \wedge 9$ & $\varepsilon, Y \varepsilon$ & 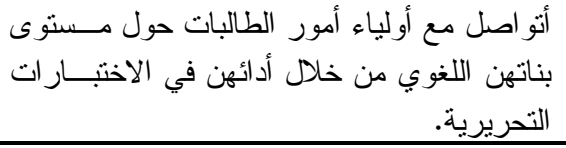 & 11 \\
\hline كبيرة جداً & 0 & 1,0 . & $\varepsilon, r \varepsilon$ & الارجة الكلية & \\
\hline
\end{tabular}

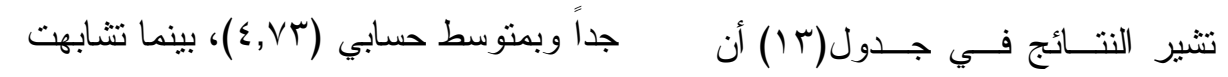

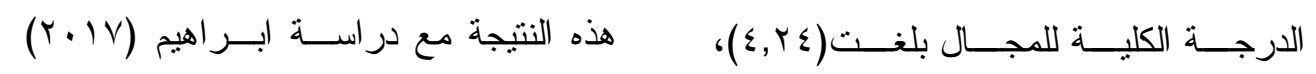

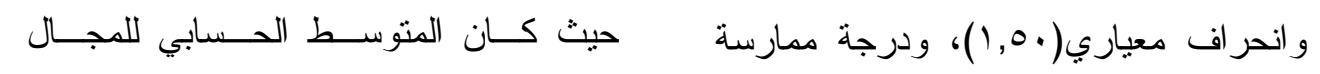

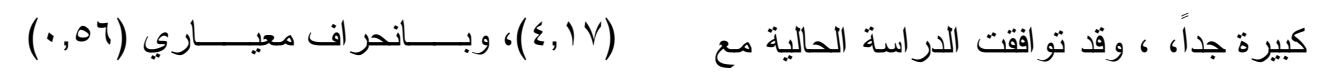

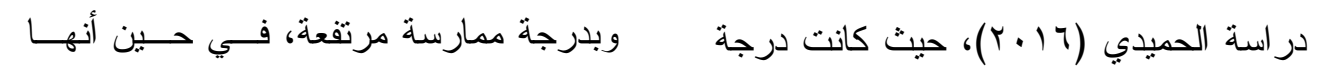

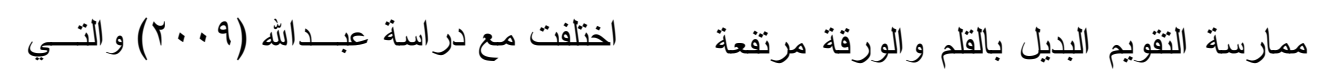


التحريرية صياغة و اضحة ومحددة نرتقـي

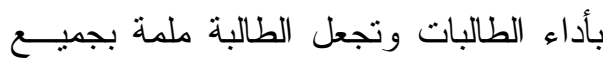

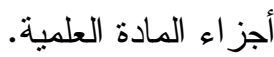

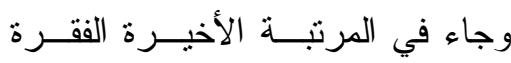

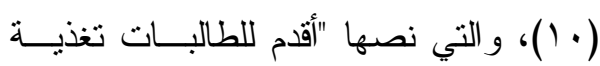
راجعة حول مستوى تحصيلهن اللغوي مسن خلال أدائهن في الاختبـــار ات التحريريــــة."

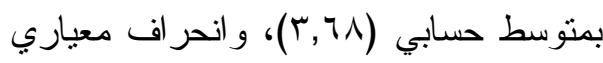

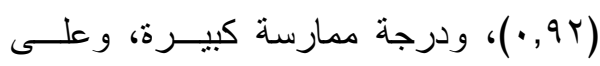

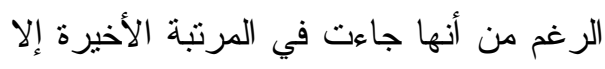

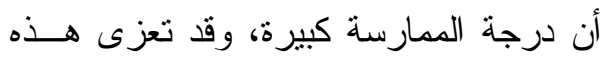

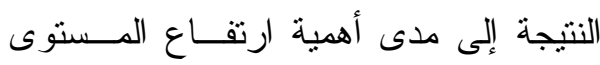
اللغوي لدى الطالبات حتى يحدث تقدم فـي الـي المستوى اللغوي للطالبات ولما لذلك من دور التغذية الر اجعة في تحسين العملية التعليميــة و الارتقاء بمسنوى الطالبات. وقد قامت عدد من الدراسات على استخدام التقــــيم البــديل بالقلم و الورقة ومنها در اســـة (الحر احسـشة،

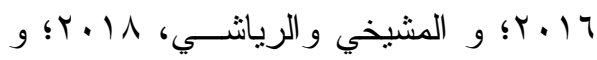

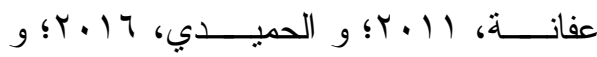
عبدالله، 9 . . r). و.التقويم البديل القائم على الأقران تم حـساب المتوســـات الحــسابية و الانحر افات المعيارية كما فيجدول (ع ().
كانت درجة ممارسة التقويم بالقلم و الورقــة

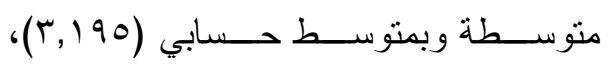

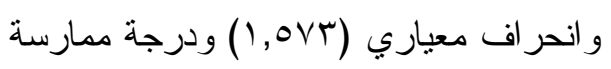
متوسطة. كما تشير النتائج إلى أن (^) فقــر ات

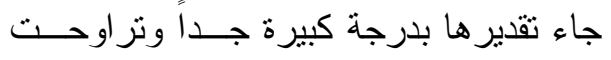

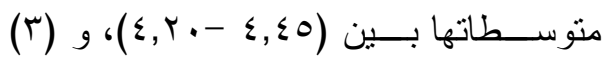

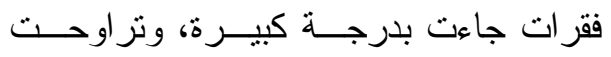
منوسطاتها بين (1) وقد جاءت الفقرة (ع) فـــي المرتبــة

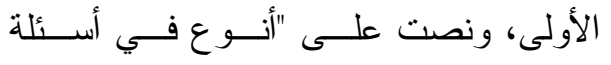
الاختبار ات التحريريــة المـستخدمة لتقيــيم مستوى الطالبات اللغوي." بمنوسط حسـسابي

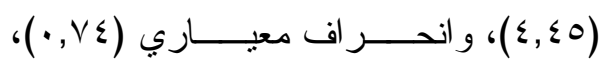
ودرجة ممارسة كبيرة جداً، وهذا يعزى إلى

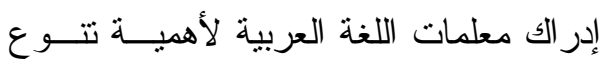
أسئلة الاختبار ات التحريرية المستخدمة لتقييم مستوى الطالبات اللغوي بالإضافة إلى أنهـــا

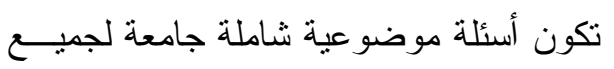
أجز اء المنهج. وجاءت الفقرة (r) في المرتبة الثانية

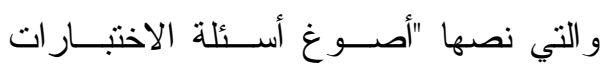

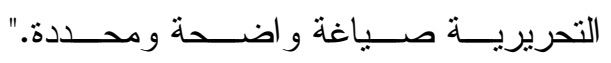
بمتوسط حسابي (r), ؛)، و انحر اف معياري

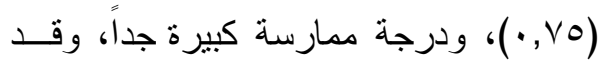

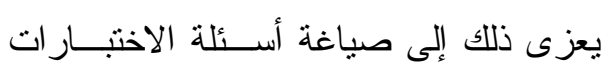


جدول(؛ 1). المتوسطات الحسابية والاحر افات المعيارية لمجال التقويم البديل

القائم على الأقران حسب متوسطاتها الحسابية

\begin{tabular}{|c|c|c|c|c|c|}
\hline الارجة & الرتبة & الالحر افياري & المتوسطي & الفقرات & الرقم \\
\hline كبيرة & $\varepsilon$ & $\cdot, 9 r$ & $\Gamma, \wedge \vee$ & من نطبيقه. أطالبات بمفهوم التقويم القائم على الأقران، و الهدف & 1 \\
\hline كبيرة & $\varepsilon$ & $\cdot, \wedge \varepsilon$ & $\varepsilon, \cdot \wedge$ & 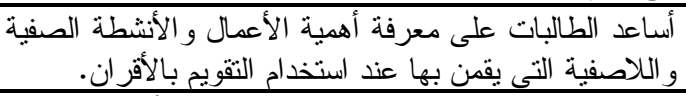 & r \\
\hline كبيرة & $\varepsilon$ & $\cdot, \vee \vee q$ & $r, 9 q$ & وأثنجع الطالبات على تقويم بعضهن البعض للأعمال الصفية & $r$ \\
\hline كبيرة & $\varepsilon$ & $\cdot, 10$ & $\varepsilon, \cdot r$ & بالثنجع الطالبات على التفكير الإيجابي عند استخدام التقويم & $\varepsilon$ \\
\hline كبيرة & $\varepsilon$ & $\cdot, \wedge \vee$ & $\varepsilon, .0$ & وأثجع الطالبات على عرض أعمالهن وتقويمها بالقرينات & 0 \\
\hline كبيرة & $\varepsilon$ & $\cdot, \wedge)$ & $\varepsilon, 1 V$ & أوجأوران. الطالبات إلى عدم التحيز لقرينة دون أخرى عند التقويم & 1 \\
\hline كبيرة & $\varepsilon$ & $\cdot, \wedge 1$ & $r, q \leq$ & 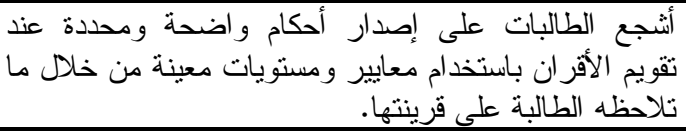 & V \\
\hline كبيرة & $\varepsilon$ & $\cdot, \wedge 9$ & $r, q 1$ & أثنجع الطالبات على تقويم قريناتهن بالأللة و البر اهين عند & $\wedge$ \\
\hline كبيرة & $\varepsilon$ & $\cdot, 9 r$ & $\varepsilon, .0$ & يقدمنه. أشالبات على احتر ام أر اء القرينات للتقييم الذي & 9 \\
\hline كبيرة & $\varepsilon$ & $\cdot, 10$ & $\varepsilon, \cdot 1$ & وأثجع الطالبات على تقديم تغذية راجعة لقريناتهن بشفافية & 1. \\
\hline كبيرة & $\varepsilon$ & $\cdot, \cdot 1$ & $\varepsilon, \cdot 1$ & الارجة الكلية & \\
\hline
\end{tabular}

ودرجة ممارسة كبيرة، وهذا يعـزى إلــى لهـ

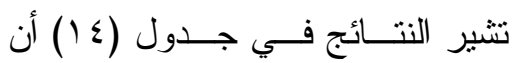

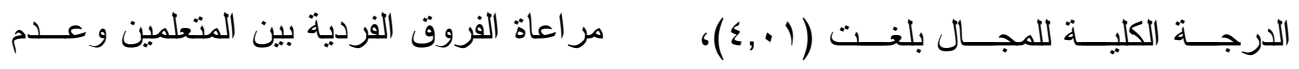

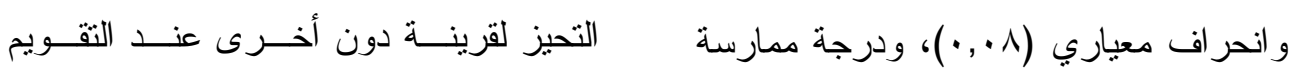

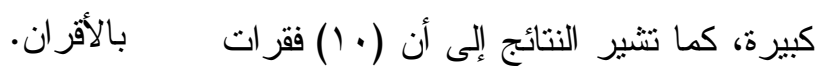

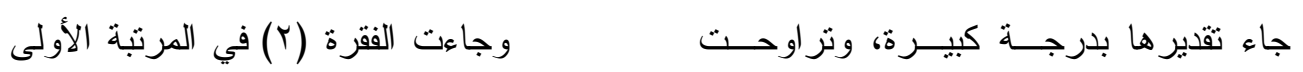

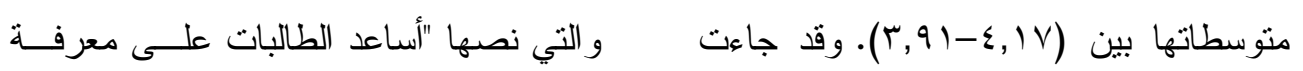

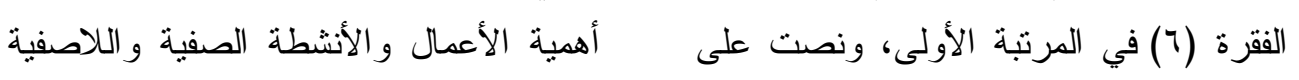

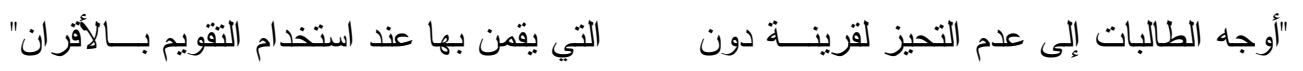

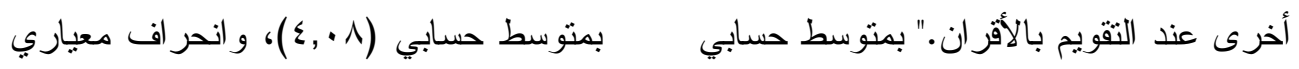

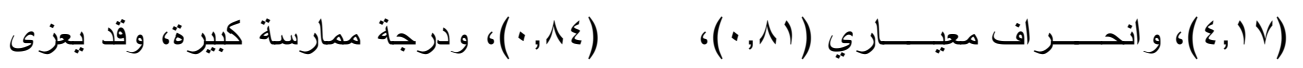


وفي در اسات سابقة كدر اسة المطرفي

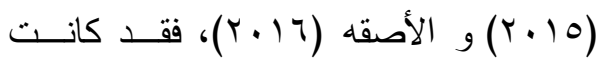

درجة الممارسة لمجــال التقــــــــــالأقران

متوسطة، وفي دراســة إبــر اهيم (Y. V (Y)

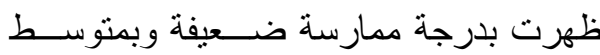

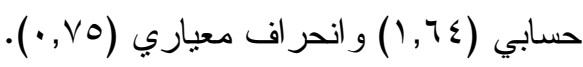

ز.التقويم البديل القائم على الأداء

تم حسـاب المتوســـات الحسـابية

و الانحر افات المعيارية كما في جدول (10).
ذلك إلى معرفة أهمية الأعمــال والأنـشطة

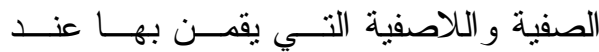

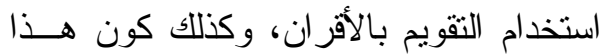
النوع من التقويم لايتتاسب كثير اً مع طالبات

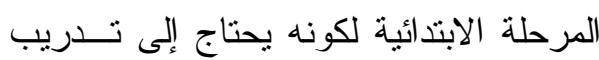
لإكساب الطالبات القدرة على إصدار الأحكام و النقد الموضوعي وكون نضجهم الفكـري و العمري يجعلهم أقل قدرة على استخدام هذا

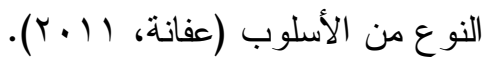
جدول(0 1) المتوسطات الحسابية والانحر افات المعيارية لمجال التقويم البديل القائم على الأداء حسب متوسطاتها الحسابية

\begin{tabular}{|c|c|c|c|c|c|}
\hline 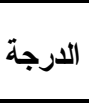 & 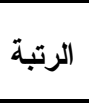 & المعياري & المسابي & الفقرات & الرق \\
\hline كبيرة & $\varepsilon$ & $\cdot, \wedge т$ & $\varepsilon, 1 T$ & أطالبات بائمة بالمهار ات اللغوية المطلوب تعلمها وتعرف & 1 \\
\hline 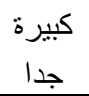 & 0 & $\cdot, \mathrm{V} V$ & $\varepsilon, r)$ & (فردي/ للطالبات نمط الأداء اللغوي المستخدم في التقويم & r \\
\hline كبيرة & $\varepsilon$ & $\cdot, \wedge т$ & r,97 & ألغة العربية. للطات جدولا زمنيا للإعداد و الأداء في تعلم & r \\
\hline كبيرة & $\varepsilon$ & $\cdot, \mathrm{V} V$ & $\varepsilon, r_{0}$ & حياتهنع الطالبات على توظيف مهار ات اللغة وتطبيقها في & $\varepsilon$ \\
\hline كبيرة & $\varepsilon$ & •,Ar & $\varepsilon, .9$ & الأثنجع الطالبات للممارسة المتميزة لمانخدام أنثطنة في اللغة العربية في نقويم & ० \\
\hline كبيرة & $\varepsilon$ & $\cdot, \wedge \Lambda$ & $r, 99$ & أللازمة للنعلم. & 1 \\
\hline كبيرة & $\varepsilon$ & $\cdot, \wedge \varepsilon$ & $\varepsilon, 1 \pi$ & أثجع الطالبات على العرض بالإلقاء. & $\mathrm{v}$ \\
\hline كبيرة & $\varepsilon$ & • & $r, 9)$ & أنثجع الطالبات على العرض بالملصقات. & $\wedge$ \\
\hline كبيرة & $\varepsilon$ & $\cdot, 99$ & $r, 7)$ & أثنجع الطالبات على العرض من خلال الندو ات. & 9 \\
\hline كبيرة & $\varepsilon$ & . & $r, q \mu$ & 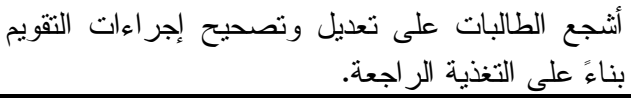 & 1. \\
\hline كبيرة & $\varepsilon$ & $\cdot, \mathrm{AV}$ & $\varepsilon, \cdot V$ & أر اقب مر احل أداء الطالبات لمهماتهن التعليمية لتقويمها. & 11 \\
\hline كبيرة & $\varepsilon$ & $\cdot, 1 \mathrm{~V}$ & $\varepsilon, \cdot r$ & الارجة الكلية & \\
\hline
\end{tabular}


بمتوسط حسابي(0, ؛ )،و انحر اف معيـاري

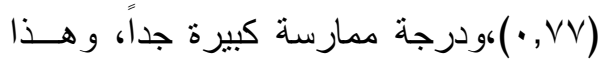

تشير النتــائج فـي جـدول(10) أن

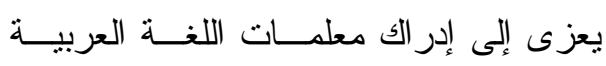

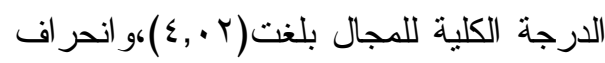
لأهمية توظيف مهار ات اللغة وتطبيقها فـي

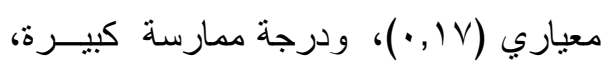
حياة الطالبات.

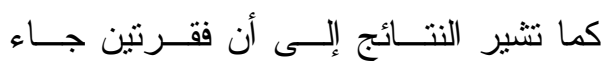

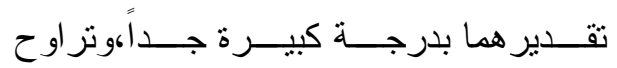
وجاء في المرنبة الأخيرة الفقرة (9)،

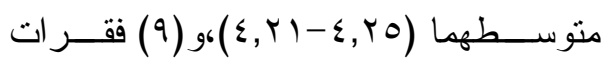

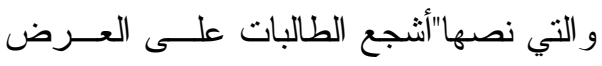
جاءت بدرجة كبيرة، وتر اوحت متوســـاتها

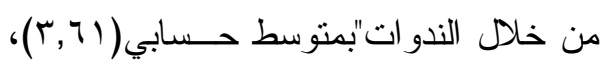
بين(r) و انحر اف معياري (99, , •)،ودرجة ممارسة لقد كانت درجة ممارسة التقويم البديل كبيرة، وقد تعزى هذه النتيجة إلى مدى أهمية القائم على الأداء مرتفعة كما فــي دراســة دماتة

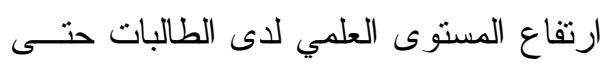

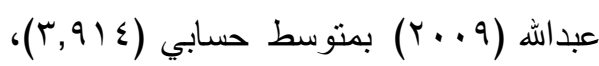
يحدث نقدم في المستوى اللغـــوي للطالبــات

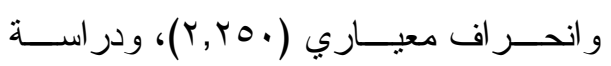

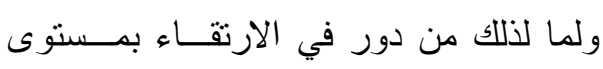

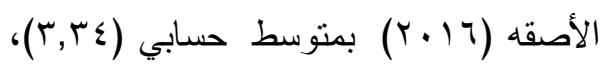
و انحر اف معياري (• (1, )، وبدرجة ممارسة الطالبات. ح.التقويم البديل القائم على المقابلة تم حسـاب المتوســـات الحـسـابية متوسطة فـي كـلـل مــن در اســة(إبــر اهيم

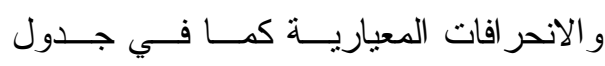

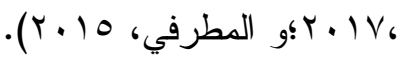
(1)

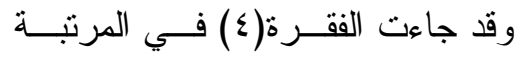

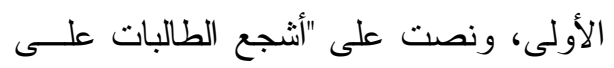
توظيف مهار ات اللغة وتطبيقها في حبــاتهن" 
جدول( 1 ). المتوسطات الحسابية والانحر افات المعيارية لمجال التقويم البديل القائم

على المقابلة حسب متوسطاتها الحسابية

\begin{tabular}{|c|c|c|c|c|c|}
\hline الارجة & الرتبة & 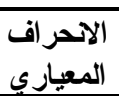 & الحسابي & الفقرات & الرقم \\
\hline كبيرة & $\varepsilon$ & $\cdot, 97$ & $r, \Lambda r$ & أبين للطالبات الهذف من إجر اء المقابلة. & 1 \\
\hline كبيرة & $\varepsilon$ & $\cdot, 97$ & $r, q 1$ & أوضح للطالبات كيفية استخدام الدقابلة لتقبيم مستو اهن اللغوي. & $r$ \\
\hline كبيرة & $\varepsilon$ & $\cdot, \wedge \Lambda$ & $r, 9 \Lambda$ & أهيئ الطالبات نفسيا و علميا قبل إجر اء التقو يح بالمقابلة. & $\bar{r}$ \\
\hline كبيرة & $\varepsilon$ & $\cdot, \wedge \mathrm{V}$ & r,人 & وصدق جدول المبلة في تقفيبم المستوى في أسئلة المقابلة للنحقق من ثبات & $\varepsilon$ \\
\hline كبيرة & $\varepsilon$ & $\cdot, \wedge 9$ & $\varepsilon, .0$ & أطر ح سلسلة من الأسئلة الو اضحة و السهلة و المعدة مسبقاً. & o \\
\hline كبيرة & $\varepsilon$ & $\cdot, \wedge \mathrm{V}$ & $\varepsilon, 17$ & ومقنجع دون خوف أولى خجل. عرض إجاباتهن بطريقة و اضحة & 7 \\
\hline كبيرة & $\varepsilon$ & $\cdot, 9 \pi$ & $\varepsilon, \cdot \varepsilon$ & أصحح أخطاء الطالبات اللغوية بعد المقابلة. & $\mathrm{v}$ \\
\hline كبيرة & $\varepsilon$ & $\cdot, \wedge 9$ & $\varepsilon, \cdot V$ & أثناء ألدقابلة. الطالبات وقتا مناسبًا للإجابة و التعليل و التوضيح & $\Lambda$ \\
\hline كبيرة & 。 & $\cdot, \wedge$ & $\varepsilon, r$. & أأعود الطالبات في الوقت المحدد. مهارة ضبط الوقت، و الإجابة عن & 9 \\
\hline كبيرة & $\varepsilon$ & •, 94 & $\varepsilon, \cdot \varepsilon$ & أدون كل ما يُطر ح من أسئلة و إجابات أثناء مقابلتها للطالبات. & 1. \\
\hline كبيرة & $\varepsilon$ & $\cdot, 91$ & $\varepsilon, \cdot \Lambda$ & أطرالبات جميع المعلومات التي جمعتها من خلال المقابلة مع & 11 \\
\hline كبيرة & $\varepsilon$ & $\cdot, \wedge 9$ & $\varepsilon, 10$ & 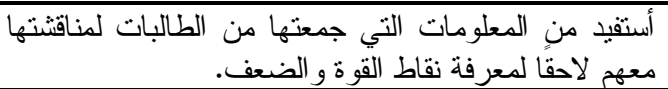 & ז \\
\hline كبيرة & $\varepsilon$ &., 14 & $\varepsilon, \cdot r$ & الارجة الكلية & \\
\hline
\end{tabular}

اللغة العربية لأهمية الوقــت، وأنـــه مــورد

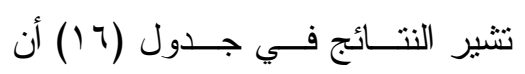

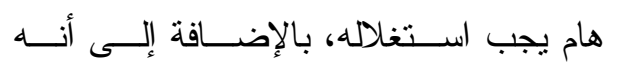

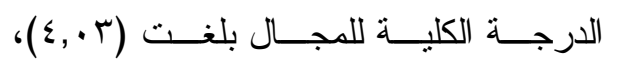

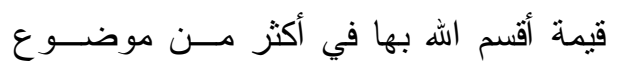

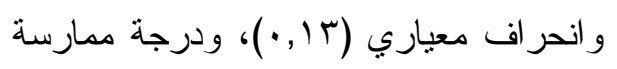

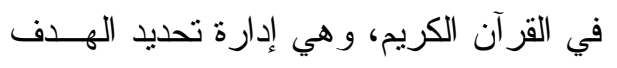

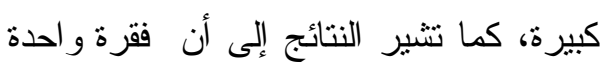

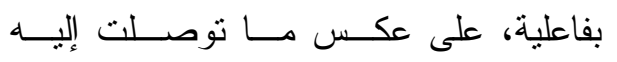

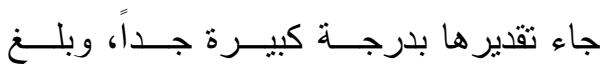

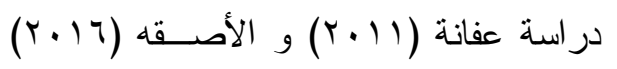

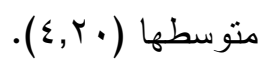

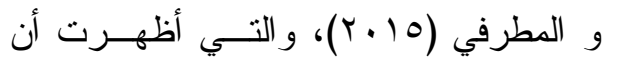

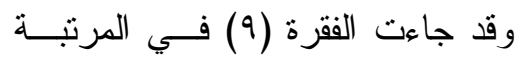

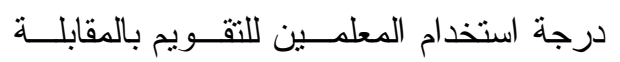

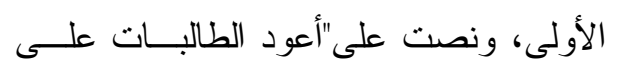

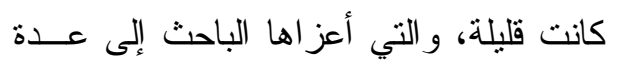

مهارة ضبط الوقت، والإجابة عن الأسئلة في

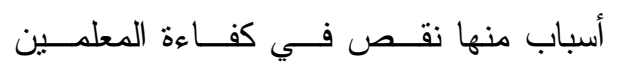

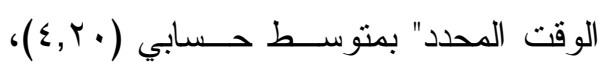

لاستخدام هذا النوع من أساليب التقويم البديل

و انحر اف معياري (1), ())، ودرجة ممارسة

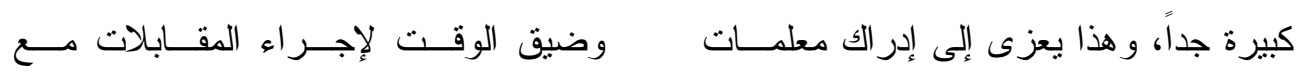


المرحلة الابتدائية تبعا لمتغيــرات الدراســـة

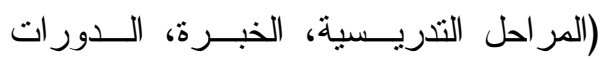

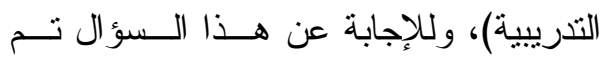
حساب المتوسطات الحــسابية و الانحر افــات ولتهاته المعيارية، و اختبار (ت)، و اختبــار تحليــل

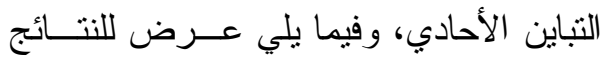
التي تم التوصل إليها.

أ. الفروق بين المتوسطات تبعــا لمتغيـر المر احل التدريسية

للكثف عن الدلالة الإحصائية للفروق

بين متوسطات تقدير أفراد عينــة الدراســـة

للدرجة اســتخدام معلمــات اللغـــة العربيـــة لاستر اتيجيات التقويم البــديل تبعــــا لمتغيـــر المر احل التّريسية، فقد تم استخدام اختبـار (ت) للمقارنة بين منوسطين مسـتقلين كمــا يبين الجدول (lv). (lv)
المتعلمين وكثافة مناهج اللغة العربية التـي يقومون بندريسها. وجاءت الفقرة (؟) في المرتبة الثانية

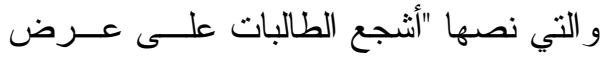
إجاباتهن بطريقة و اضحة ومقنعة دون خوف

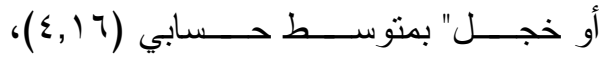
و انحر اف معياري (AV, · )، ودرجة ممارسة

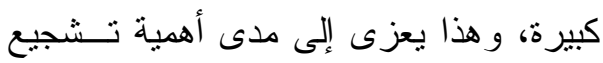

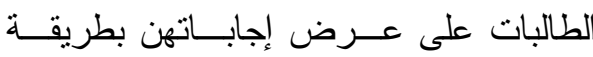
و اضحة ومقنعة دون خوف أو خجل.

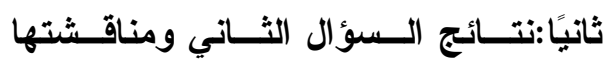

$$
\text { وتفسير ها }
$$

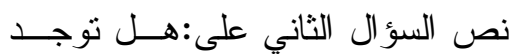

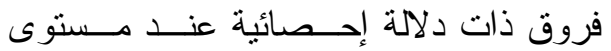

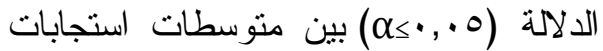

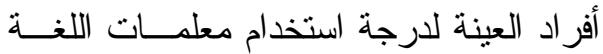

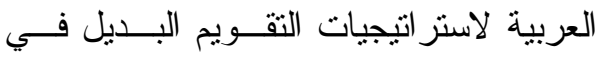
جدول(I ). اختبار (ت) لاستجابات أفر اد عينة الدراسة على مجالات أداة الدراسة تبعا لمتغير المراحل التدريسية

\begin{tabular}{|c|c|c|c|c|c|c|}
\hline \multicolumn{2}{|c|}{ اختبار ت } & \multicolumn{2}{|c|}{ صفوف عليا (Ar) } & \multicolumn{2}{|c|}{ صفوف دنيا (^^) } & \multirow[b]{2}{*}{ المجالات } \\
\hline مستوى الدلاكة & ق ق قيمة ت & معياري & مسابي & اتحعر اف & مسابي & \\
\hline$\cdot, \cdots 1$ & $* q, r$. & $\cdot, \vee \wedge \wedge$ & $\varepsilon, \Upsilon \wedge$ & $\cdot, 9 \leq$ & $r, \cdot \varepsilon$ & التقويم البديل القائُ على الاتصسال \\
\hline$\cdot, \cdots 1$ & $* \wedge, \vee 9$ & $\cdot, \wedge \varepsilon$ & $\varepsilon, \cdot V$ & $\varepsilon, \cdot V$ & $r, \wedge 0$ & التقويم البديل القائع على الإنجاز \\
\hline$\cdot, \cdots 1$ & $* 9,7 V$ & $\cdot, \vee \vee \uparrow$ & $\varepsilon, Y, r$ & $\cdot, 91$ & r, १V & التقويم البديل القائح على التقويم الذاتي \\
\hline$\cdot, \cdots 1$ & $* q, \Gamma q$ & $\cdot, \mathrm{VT}$ & $\varepsilon, r V$ & $\cdot, 91$ & $r, 11$ & التقويم البديل القائم على الملاحظة \\
\hline$\cdot, \cdots 1$ & $* 9, \wedge 1$ & $\cdot, \mathrm{V} \varepsilon$ & $\varepsilon, Y_{0}$ & $\cdot, \wedge 9$ & $r, \cdot 1$ & التقويم البديل القائم على القلم و الورقة \\
\hline$\cdot, \cdots 1$ & $* q, \Sigma r$ & $\cdot, \mathrm{VA}$ & $\{, 17$ & $\cdot, 97$ & $r, \wedge 9$ & التقويم البديل القائم على الأقر ان \\
\hline$\cdot, \cdots 1$ & $* \wedge, \cdot 0$ & $\cdot, \wedge 7$ & $\varepsilon, 1 T$ & $1, \cdot r$ & $r, 90$ & التقويم البديل القائم على الأداء \\
\hline$\cdot, \ldots 1$ & $* \wedge, \Gamma_{0}$ & $\cdot, \wedge \wedge$ & $\varepsilon, \cdot r$ & $\cdot, 9 \mathrm{~V}$ & $r, \wedge r$ & التقويم البديل القائم على المقابلة \\
\hline$\cdot, \cdots 1$ & $* \|, r V$ &., 09 & $\varepsilon, Y q$ & $\cdot, 9$. & $r, 90$ & الارجة الكلية \\
\hline
\end{tabular}

* دال إحصائيا عند مستوى دلالة (0., •). 
ويليه تقويم الأقران ثم التقويم القـائم علــى الأداء ثم ملفات الانجاز ثم في الأخير التقويم

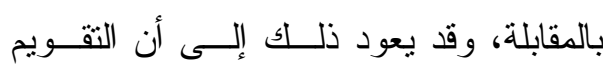

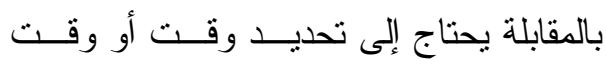

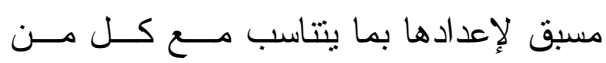

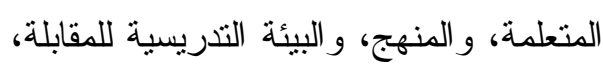

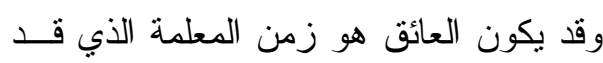

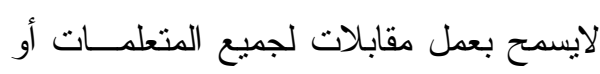

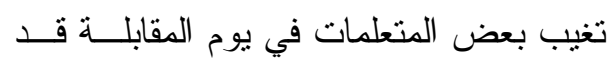
يؤدي إلى عدم القيام بهذا النوع من التقــــيم

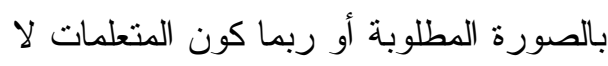

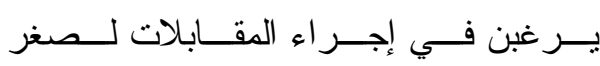

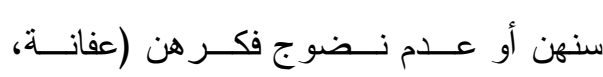
$\cdot(r \cdot)$ ب- الفروق بين المتوسطات تبعاً لمتغيــر سنوات الخبرة

للكثف عن الدلالة الإحصائية للفروق بين متوسطات تقدير أفر اد عينــة الدراســـة الإحسة

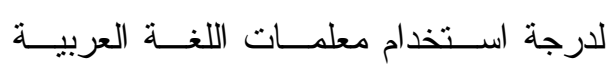
لاستر اتيجيات الثقويم البــديل تبعـــا لمتغيــر

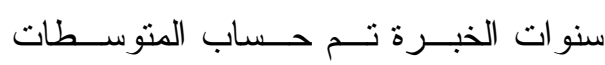

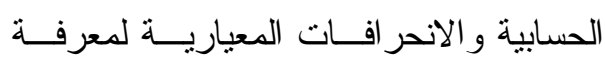

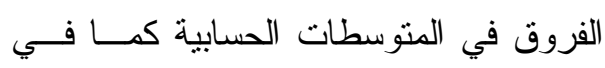

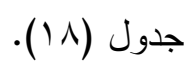

تـشير النتــائج فــي جـدول (IV)

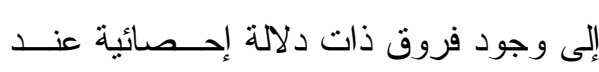

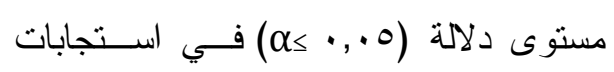

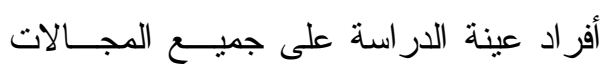

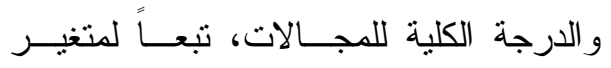
المر احل التدريسية وقد جاءت الفروق لصالح فئة الصفوف العليا، وهذا قد يعزو إلـى أن هذه الفئة هي الأكثر تفاعلا مع الطالبات في

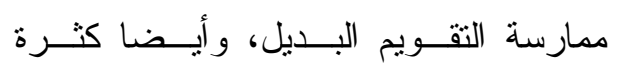
ممارستهم للعمل. لوحظ مسن جـدول رقـم (lV)، أن التقويم البديل القائم على الملاحظة كان فـي

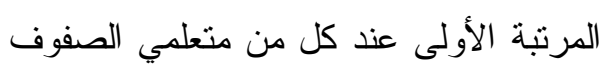

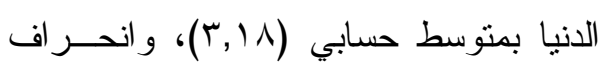
معياري (19, •)، مقارنة مع بقية المجــالات

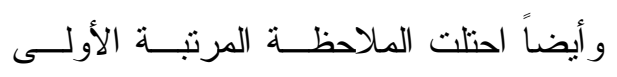

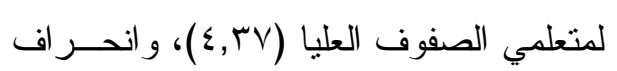

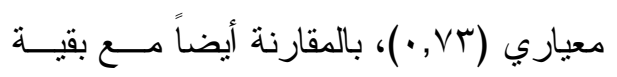

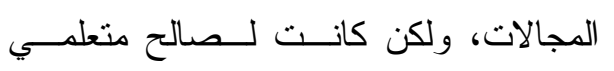

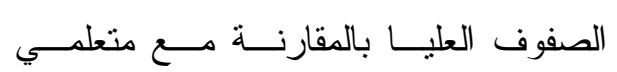
الصفوف الدنيا. وكان ترتيب بقية مجــالات التقــويم

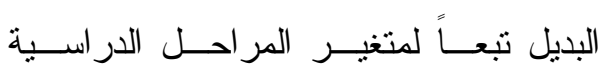

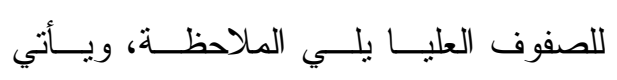
الاتصال ثم القلم و الورقة ويليه التقويم الذاتي 
جدول(1 1). المتوسطات الحسابية والاتحر افات المعيارية لمجالات أداة

الار اسة تبعا لمتغير سنوات الخبرة

\begin{tabular}{|c|c|c|c|c|}
\hline الانحر اف & المتوسط الحسابي & ا العدد & الدورات التدريبية & المجالات \\
\hline$\cdot, V Y$ & $r, 00$ & 9 & أقل من 0 سنو ات & \multirow{3}{*}{ التقويم البديل القائم على } \\
\hline $1, \cdot r$ & $r, r q$ & TV & منه- . 1 سنو ات & \\
\hline$\cdot, 7 Y$ & $\varepsilon, \Gamma \wedge$ & $1 \pi \varepsilon$ & أكثر من · اسنو ات & \\
\hline$\cdot, 7$ & $r, 11$ & 9 & أقل من 0 سنو ات & \multirow{3}{*}{ التقويم البديل القائم على } \\
\hline $1,1 \leq$ & $r, \cdot v$ & rV & منه- ، ا سنو ات & \\
\hline$\cdot, \uparrow \wedge$ & $\varepsilon, Y T$ & $1 \pi \varepsilon$ & أكثر من · اسنوات & \\
\hline$\cdot, 77$ & $r, Y r$ & 9 & أقل من 0 سنو ات & \multirow{3}{*}{ التقويم البديل القائم على التقويم } \\
\hline .,9r & $r, \cdot r$ & TV & منه- ، ا سنوات & \\
\hline$\cdot, 9 r$ & $r, q r$ & $1 \pi \varepsilon$ & أكثر من · اسنو ات & \\
\hline$\cdot, \mathrm{TV}$ & $r, r_{1}$ & 9 & أقل من 0 سنو ات & \multirow{3}{*}{ التقويم البديل القائم على } \\
\hline 1,1 . & سז, & TV & منه- ، 1 سنوات & \\
\hline$\cdot, 7 \mathrm{~V}$ & $\varepsilon, Y V$ & $1 \pi \varepsilon$ & أكثر من · اسنوات & \\
\hline$\cdot, \vee \wedge$ & $r, 11$ & 9 & أقل من 0 سنو ات & \multirow{3}{*}{ التقويم البديل القائم على القلم } \\
\hline$\cdot, 94$ & $r, \wedge)$ & rV & منه- ، ا سنوات & \\
\hline$\cdot, 9$ & $r, \wedge \wedge$ & $1 \pi \varepsilon$ & أكثر من · اسنو ات & \\
\hline$\cdot, \times 1$ & ש זיזr & 9 & أقل من ه سنو ات & \multirow{3}{*}{ التقويم البديل القائم على الأقران } \\
\hline$\cdot, 9 \varepsilon$ & $r, 1 \leq$ & TV & منه- • سنوات & \\
\hline$\cdot, 71$ & $\varepsilon, \varepsilon Y$ & 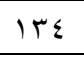 & أكثر من · اسنوات & \\
\hline$\cdot, 7$ & r,ir & 9 & أقل من 0 سنوات & \multirow{3}{*}{ التقويم البديل القائم على الأداء } \\
\hline $1, .9$ & r, ro & tr & منه- · م سنوات & \\
\hline$\cdot, 71$ & $\varepsilon, r \varepsilon$ & $1 \pi \varepsilon$ & أكثر من · اسنوات & \\
\hline $1, .0$ & $r, 11$ & 9 & أقل من 0 سنو ات & \multirow{3}{*}{ التقويم البديل القائم على } \\
\hline$\cdot, 9 \mathrm{~V}$ & r,ir & rV & منه- ، ا سنوات & \\
\hline$\cdot, 71$ & $\varepsilon, \varepsilon Y$ & $1 \pi \varepsilon$ & أكثر من · اسنو ات & \\
\hline$\cdot, 10$ & r,r & 9 & أقل من 0 سنو ات & \multirow{3}{*}{ الارجة الكلية } \\
\hline $1,7 V$ & $r, i r$ & TV & منه- ، ـ سنوات & \\
\hline$\cdot, 77$ & $r, 9 V$ & $1 \pi \varepsilon$ & أكثر من · اسنوات & \\
\hline
\end{tabular}

يلاحظ من جدول(1/) وجود فروق المنوسطات الحسابية ذات دلالة إحصائية

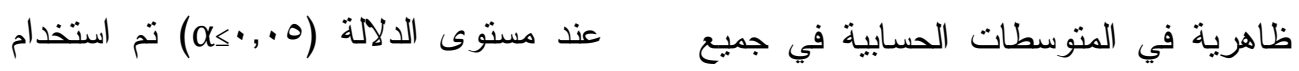
مجالات أداة الدراسة تبعا لمتغير سنوات تحليل التباين الأحادي و الذي جاءت فئ نتائجه الخبرة، ولتحديد فيما إذا كانت الفروق بين كما في جدول (19) 


\section{جدول(9 1 ). تحليل التباين الأحادي لاستجابات أفراد عينة الدراسة}

تبعا لمتغير سنوات الخبرة

\begin{tabular}{|c|c|c|c|c|c|c|}
\hline الدستوى & قيمة ف & المربعات & |درجات الحرية| & المربعوع & مصدر التباين & المجالات \\
\hline \multirow{3}{*}{$\cdot, \cdots 1$} & \multirow{3}{*}{$r \cdot, r)$} & 10,19 & $r$ & $r \cdot, \mu$ & بين المجموعات & \multirow{3}{*}{ التقويم البديل القائم على } \\
\hline & & $\cdot, 0$ & $17 V$ & $\wedge r, T \vee$ & داخل المجموعات & \\
\hline & & & 179 & $11 \leq, 0$ & الكلي & \\
\hline \multirow{3}{*}{$\cdot, \cdots 1$} & \multirow{3}{*}{ r ו,9r } & $11,9 \leq$ & $r$ & $r v, \wedge q$ & بين المجموعات & \multirow{3}{*}{ التقويم البديل القائم على الإنجاز } \\
\hline & &., 09 & 178 & $99, .9$ & داخل المجموعات & \\
\hline & & & 179 & 1157,99 & الكلي & \\
\hline \multirow{3}{*}{$\cdot, 0 r$} & \multirow{3}{*}{$\cdot, 7 \varepsilon$} & $\cdot, 0 \leqslant$. & r & $1, \cdot 1$ & بين المجموعات & \multirow{3}{*}{ التقويم البديل القائُ على التقويم } \\
\hline & & $\cdot, \wedge \varepsilon$ & 178 & $1 \leq 1, \leqslant \varepsilon$ & داخل المجموعات & \\
\hline & & & 179 & $1 \leqslant Y, O r$ & الكلي & \\
\hline \multirow{3}{*}{$\cdot, \cdots 1$} & \multirow{3}{*}{$r r, 99$} & Ir,Y. & $r$ & $r\rceil, \Sigma$. & بين المجموعات & \multirow{3}{*}{ التقويم البديل القائُ على الملاحة } \\
\hline & &., $0 \mathrm{~V}$ & 178 & $90,1 \wedge$ & داخل المجموعات & \\
\hline & & & 179 & $M r, Y \wedge$ & الكلي & \\
\hline \multirow{3}{*}{$\cdot, 79$} & \multirow{3}{*}{$\cdot$, ro } & $\cdot, r q$ & $r$ &., 09 & بين المجموعات & \multirow{3}{*}{ التقويم البديل القائم على القلم } \\
\hline & & $\cdot, \wedge r$ & $17 V$ & $1 \mu v, .0$ & داخل المجموعات & \\
\hline & & & 179 & $1 \Gamma V, T \varepsilon$ & الكلي & \\
\hline \multirow{3}{*}{$\cdot, \cdots)$} & \multirow{3}{*}{$\leqslant 0, Y \uparrow$} & $r 1, .9$ & $r$ & $\varepsilon r, 19$ & بين المجموعات & \multirow{3}{*}{ التقويم البديل القائُ على الأقران } \\
\hline & & $\cdot, \leqslant 7$ & $17 V$ & VV,Ar & داخل المجموعات & \\
\hline & & & 179 & $M \cdot, \cdot r$ & الكلي & \\
\hline \multirow{3}{*}{$\cdot, \cdots$} & \multirow{3}{*}{ ro, vo } & $1 \leqslant, 90$ & $r$ & $r q, 9$. & بين المجموعات & \multirow{3}{*}{ لتقويم البديل القائم على الأداء } \\
\hline & & $\cdot, 01$ & $17 V$ & $97,9 \leq$ & داخل المجموعات & \\
\hline & & & 179 & $1 Y 7,10$ & 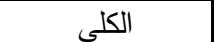 & \\
\hline \multirow{3}{*}{$\cdot, \cdots 1$} & \multirow{3}{*}{$\leqslant \wedge, 0 \leqslant$} & $r \leqslant, 0$. & r & $\varepsilon 9, \cdot 1$ & بين المجموعات & \multirow{3}{*}{ التقويم البديل القائم على } \\
\hline & & $\cdot, 01$ & $17 V$ & $\wedge \varepsilon, \Gamma$. & داخل المجموعات & \\
\hline & & & 179 & ITr,Tr & الكلي - الكي & \\
\hline \multirow{3}{*}{$\cdot, \cdots 1$} & \multirow{3}{*}{$r v, 9 r$} & $\Lambda, 0 \leqslant$ & $r$ & $1 \mathrm{~V}, \cdot 1$ & بين المجموعات & \multirow{3}{*}{ الارجة الكلية } \\
\hline & & $\cdot, r$ & $17 V$ & $01, \cdot V$ & داخل المجموعات & \\
\hline & & & 179 & $7 \wedge, 17$ & الكلي & \\
\hline
\end{tabular}

لمتغير سنوات الخبرة، و على مجـالات أداة تشير النتائج في جـدول (9 (1) إلـى

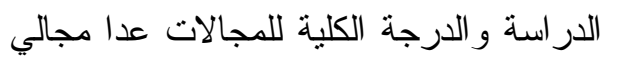
وجود فروق ذات دلالة إحصائية عند مستوى في

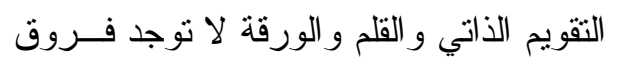

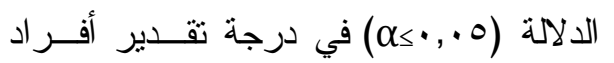
دالة إحصائية لهذين المجالين.

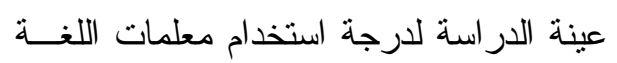

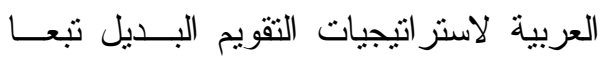


و اتفقت هذه النتيجة مع دراسة جـودة بعدم وجود فروق ذات دلالة إحصائية تبعــاً

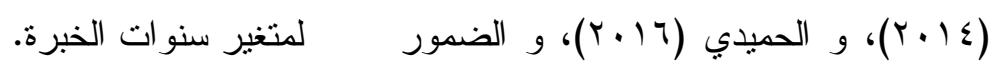

وللتعرف على اتجاه دلالـــة الفــروق

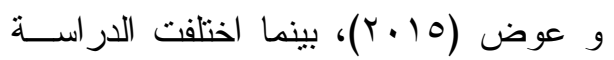

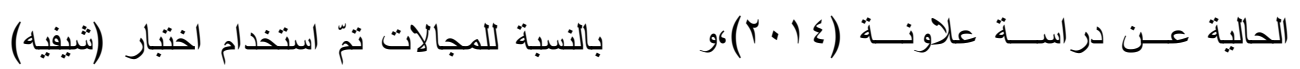

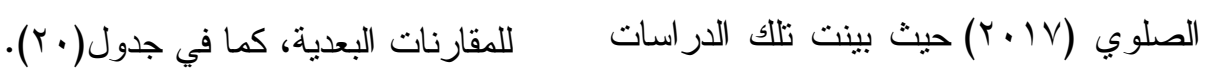
جدول(· ·). المقارنات البعدية للقروق التي ظهرت في بعض مجالات التقويم البديل تبعا لمتغير سنوات الخبرة

\begin{tabular}{|c|c|c|c|c|}
\hline أكثر من · 1 سنوات & منه- . 1 سنوات & أقل من ه سنوات & الفئات & المجالات \\
\hline$*, \wedge r$ & - & - & أقل من 0 سنو ات & \multirow{3}{*}{ القائم على البديل } \\
\hline$* 1, .9$ & - & - & منه- . 1 سنو ات & \\
\hline- & - & - & أكثر من · ا سنوات & \\
\hline$* 1,1 r$ & - & - & أقل من ه سنو ات & \multirow{3}{*}{ التقويم البديل } \\
\hline$* 1,17$ & - & - & منه- . ا سنوات & \\
\hline- & - & - & أكثر من · سنو ات & \\
\hline$* 1, \cdot \leq$ & - & - & أقل من 0 سنو ات & \multirow{3}{*}{ القائويم البديل } \\
\hline$*, 94$ & - & - & منه- . ا سنوات & \\
\hline- & - & - & أكثر من سنوات & \\
\hline$* 1, \cdot v$ & - & - & أقل من ه سنو ات & \multirow{3}{*}{ التقويم البديل } \\
\hline$* 1, r 7$ & - & - & منه- . ا سنوات & \\
\hline- & - & - & أكثر من · ا سنوات & \\
\hline *1, r & - & - & أقل من ه سنو ات & \multirow{3}{*}{ القائم على الأداء البديل } \\
\hline$*, 91$ & - & - & منه- . ا سنوات & \\
\hline- & - & - & أكثر من · ـ سنو ات & \\
\hline$* 1, \Gamma$ & - & - & أقل من ه سنو ات & \multirow{3}{*}{ القتويم البديل } \\
\hline$* 1, r q$ & - & - & منه- . ا سنوات & \\
\hline- & - & - & أكثر من · ـ سنو ات & \\
\hline$\because, \vee_{0}$ & - & - & أقل من ه سنو ات & \multirow{3}{*}{ الارجة الكلية } \\
\hline$*, \wedge 0$ & - & - & منه- . ـ سنوات & \\
\hline- & - & - & أكثر من · ( سنو ات & \\
\hline
\end{tabular}

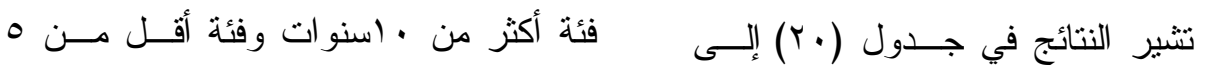

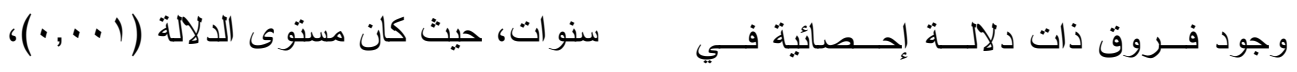

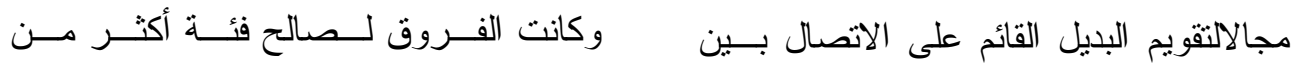


حين كان متوســط أقــل مــن م ســنوات (r, (r)

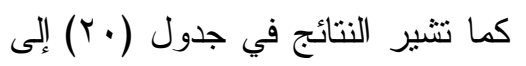

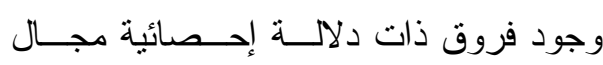

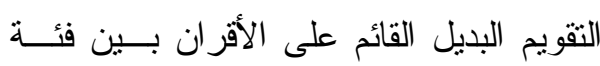

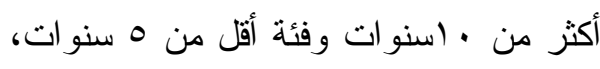
حيث كان مستوى الدلالة (1 (.., ).)، وكانت

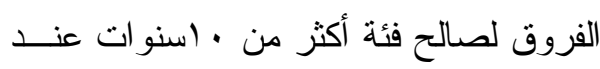

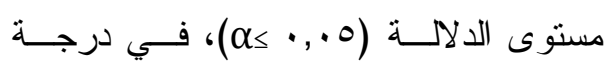
ممارسة المعلمات لدور هن في التتمية المهنية تبعاً لمتغير سنوات الخبرة، وبمنوسط حسابي لوني

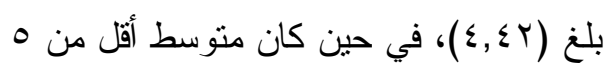

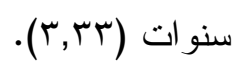

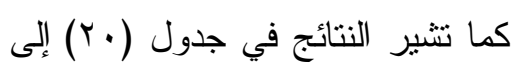

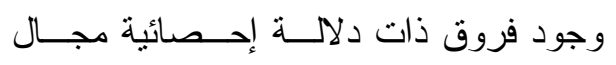

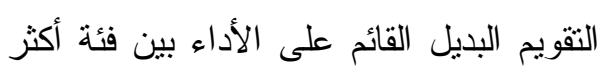

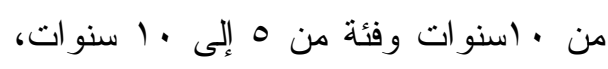

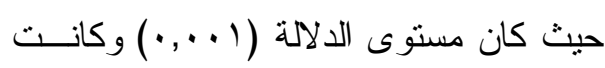

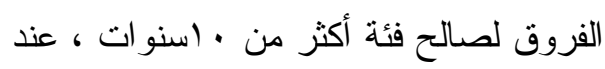

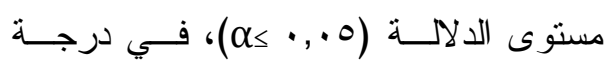
ممارسة المعلمات لدور هن في التتمية المهنية

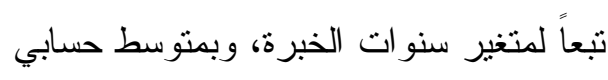

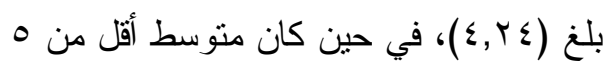

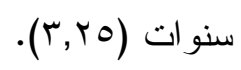

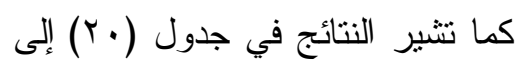

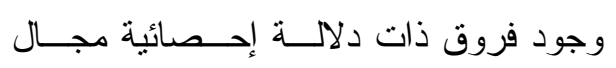
التقويم البديل القائم على المقابلة بين فئة أكثر دلر
• (سنوات عند مستوى الدلالة (0., •

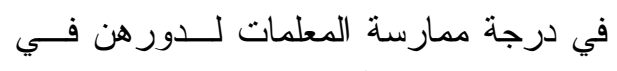

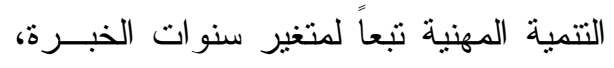
وبمتوسط حسابي بلغ (^ז,؛))، في حين كان متوسط أقل من 0 سنوات (ب,00).

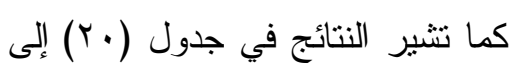

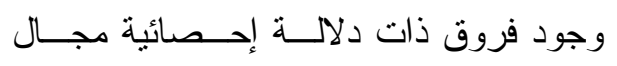

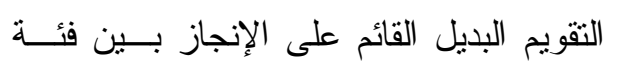

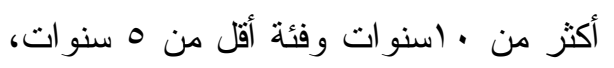
حيث كان مسنوى الدلالة (1 (.., •)، وكانت

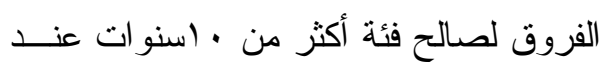

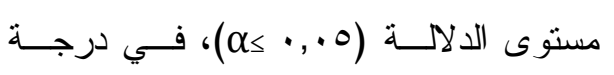
ممارسة المعلمات لدور هن في التتمية المهنية

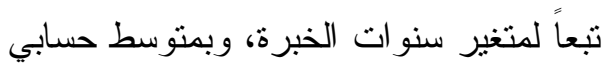

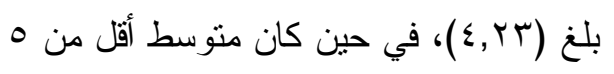

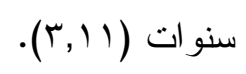

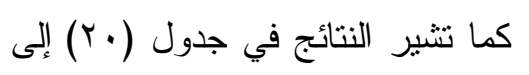

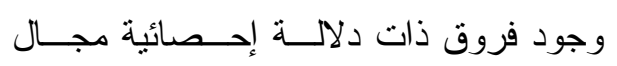
التقويم البديل القائم على الملاحظة بين فئــة دونة

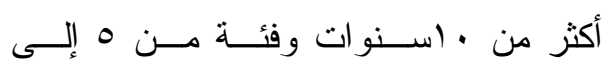

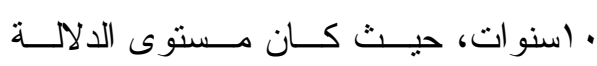

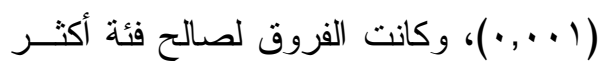
من · اسنوات عند مسنوى الدلالـــة (0.,.

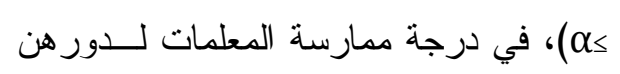

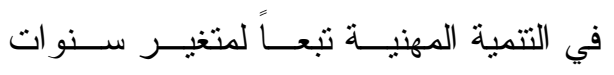

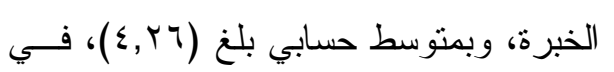


و أدوات التقويم البديل وتطبيقها كو اقـــع فــي

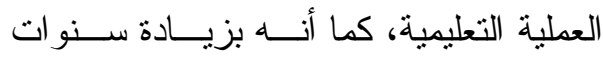

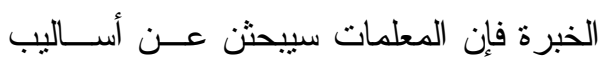
تقويم جديدة أو فعالة باستخدام أساليب التقويم

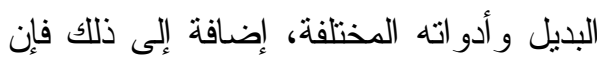

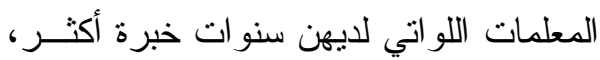

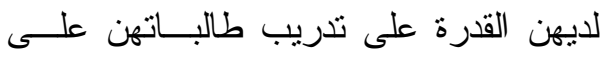

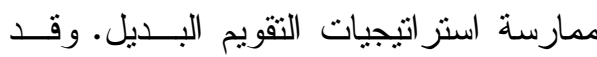

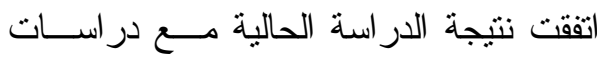

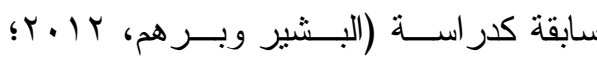

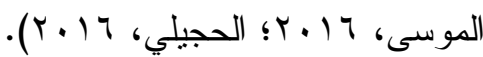
ج.الفروق بين المتوسطات تبعـا لمتغيـر الاورات التدريبية للكثف عن الدلالة الإحصائية للفروق بين متوسطات تقدير أفراد عينــة الدراســـة

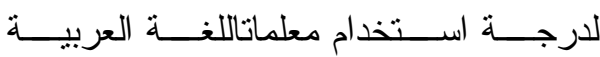

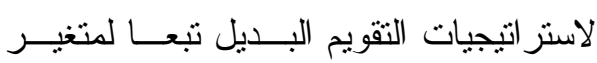

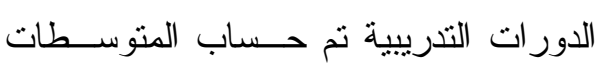
الحسابية و الانحر افــات المعياريـــة لمعرفـــة

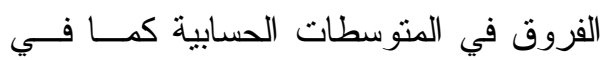
جدول (r) (r).
من · اسنوات وفئة من ه إلى · ا سنو ات،

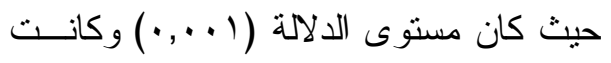
الفروق لصالح فئة أكثر من · اسنوات، عند

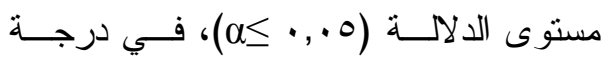
ممارسة المعلمات لدورهن في التتمية المهنية تبعاً لمتغير سنوات الخبرة، وبمتوسط حسابي

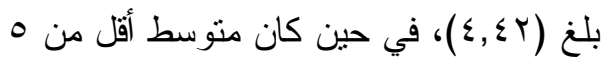

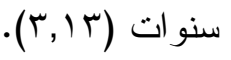
كما تتير النتائج في جدول (·r) إلى (ب) وجود فروق ذات دلالة إحصائية في الدرجة الكلية لمجالات التقويم البديل بين فئة أكثــر من · اسنو ات وفئة أقل من ه سنوات، حيث كان مستوى الدلالة (1 .., .·) وكانت الفروق لصالح فئة أكثر من · (سنوات، عند مستوى

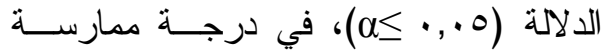

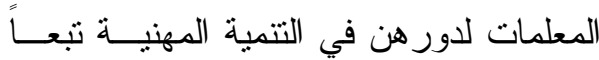
لمتغير سنوات الخبرة، وبمتوسط حسابي بلغ

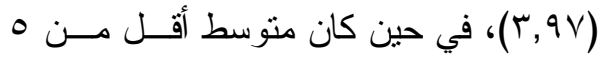

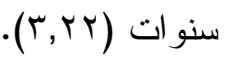
وتعزو الباحثة هذه النتيجة إلى عـدد

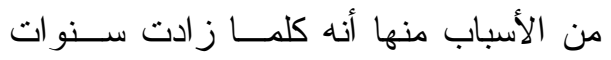

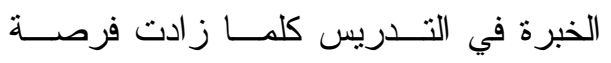
المعلمات في التعرف علــى اســتراتيجيات 


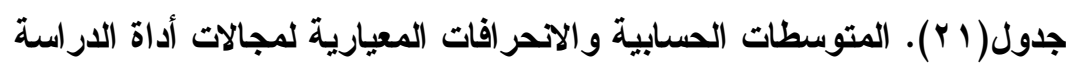

تبعا لمتغير الدورات التدريبية

\begin{tabular}{|c|c|c|c|c|}
\hline الاحمراف & المتوسط & العدد العد & الدورات التدريبية & المجالات \\
\hline$\cdot, \wedge 9$ & $r, \wedge \wedge$ & 0. & دورة إلى ثلاث دور ات & \multirow{3}{*}{ الثقويم البديل القائم على الاتصلال } \\
\hline$\cdot, 97$ & $r, \cdot \Lambda$ & 0. & أربع إلى ست دورات & \\
\hline$\cdot, 94$ & $\varepsilon, \varepsilon$. & $v$. & V دور ات فأكثر & \\
\hline$\cdot, \wedge 4$ & $r, r \cdot$ & 0. & دورة إلى ثلات دور ت & \multirow{3}{*}{ الثقويم البديل القائم على الإنجاز } \\
\hline $1, \cdot r$ & $r, q \leq$ & 0. & أربع إلى ست دور ات & \\
\hline$\cdot, 79$ & $\varepsilon, Y \varepsilon$ & $v$. & V دور ات فأكثر & \\
\hline$\cdot, \wedge \varepsilon$ & r,Ar & 0. & دورة إلى ثلاث دور ت & \multirow{3}{*}{ التقويم البديل القائم على التقويم } \\
\hline$\cdot, 90$ & $r, \cdot r$ & 0. & أربع إلى ست دور ات & \\
\hline . & $\varepsilon, r_{0}$ & $v$. & V دورات فأكثر & \\
\hline$\cdot, 94$ & $r, \cdot 1$ & 0. & دورة إلى ثلاث دور ت & \multirow{3}{*}{ التقويم البديل القائم على الملاحظة } \\
\hline$\cdot, 91$ & $r, r_{1}$ & 0. & أربع إلى ست دور ات & \\
\hline., 00 & $\varepsilon, \varepsilon 0$ & $v$. & V دور ات فأكثر & \\
\hline$\cdot, \Lambda \mathrm{r}$ & $r, \wedge)$ & 0. & دورة إلى ثلاث دور ات & \multirow{3}{*}{ التقويم البديل القائم على القلم و الورقة } \\
\hline$\cdot, 9 \varepsilon$ & $r, .9$ & 0. & أربع إلى ست دور ات & \\
\hline., $0 \mathrm{~V}$ & $\varepsilon, \varepsilon 1$ & $v$. & V دور ات فأكثر & \\
\hline$\cdot, \wedge \mathrm{V}$ & $r, V \varepsilon$ & 0. & دورة إلى ثلاث دور ت & \multirow{3}{*}{ الثقويم البديل القائم على الأقران } \\
\hline $1, \cdot r$ & $r, 90$ & 0. & أربع إلى ست دور ات & \\
\hline$\cdot, 70$ & $\varepsilon, Y V$ & $v \cdot$ & 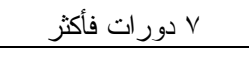 & \\
\hline$\cdot, \wedge 9$ & $r, V T$ & 0. & دورة إلى ثلاث دور ات & \multirow{3}{*}{ التقويم البديل القائم على الأداء } \\
\hline $1, .9$ & $r, . r$ & 0. & أربع إلى ست دور ات & \\
\hline$\cdot, \mathrm{v} \cdot$ & $\varepsilon, Y V$ & $\mathrm{v}$. & V دور ات فأكثر & \\
\hline$\cdot, \wedge \mathrm{V}$ & $r, 74$ & 0. & دورة إلى ثلات دور ت & \multirow{3}{*}{ التقويم البديل القائم على المقابلة } \\
\hline $1, \cdot 7$ & $r, \vee \wedge$ & 0. & أربع إلى ست دور ات & \\
\hline$\cdot, 70$ & $\varepsilon, 1 V$ & $v$. & V دور ات فأكثر & \\
\hline$\cdot, 11$ & r,vq & 0. & دورة إلى ثلاث دورت & \multirow{3}{*}{ الارجة الكلية } \\
\hline$\cdot, 1 \mathrm{r}$ & $r, \cdot r$ & 0. & أربع إلى ست دور ات & \\
\hline$\cdot, .9$ & $\varepsilon, r$ r & $v$. & V دور ات فأكثر & \\
\hline
\end{tabular}

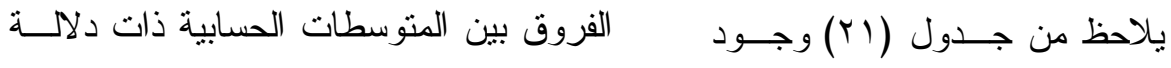

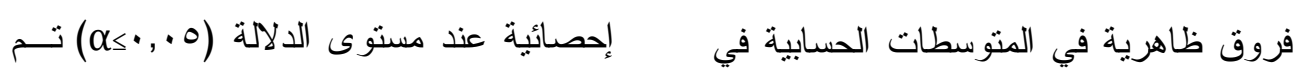

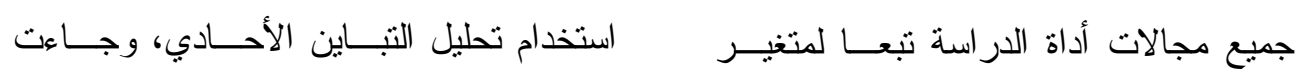

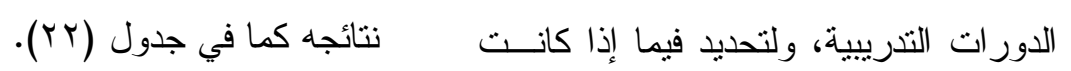




\begin{tabular}{|c|c|c|c|c|c|c|}
\hline \multicolumn{7}{|c|}{ جدول(Y Y ). تحليل التباين الأحادي لاستجابات أفراد عينة الدراسة تبعا } \\
\hline مستوى & قيمة ف & المربعات & الحرجاتة & مجموع المربعات & مصدر التباين & المجالات \\
\hline \multirow{3}{*}{$\cdot, \cdots 1$} & \multirow{3}{*}{$T r, V \wedge$} & $\sum r, \cdot r$ & r & $\Lambda \varepsilon, \cdot r$ & بين المجموعات & \multirow{3}{*}{ التقويم البديل القائم على الآل } \\
\hline & & $\cdot, 77$ & 178 & 111,87 & داخل المجموعات & \\
\hline & & & 179 & $190, \mathrm{VA}$ & الكلي & \\
\hline \multirow{3}{*}{$\cdot, \cdots 1$} & \multirow{3}{*}{$0 \wedge, 91$} & $\{r, \varepsilon 1$ & $r$ & $\wedge \varepsilon, \wedge)$ & بين المجموعات & \multirow{3}{*}{ التقويم البديل القائم على } \\
\hline & & $\cdot, V Y$ & $17 V$ & $14 \cdot, 19$ & داخل المجمو عات & \\
\hline & & & 179 & $r \cdot \varepsilon, 99$ & الكلي & \\
\hline \multirow{3}{*}{$\cdot, \cdots 1$} & \multirow{3}{*}{$7 V, 91$} & $\varepsilon r, \cdot r$ & $r$ & $\Lambda \uparrow, \cdot \varepsilon$ & بين المجموعات & \multirow{3}{*}{ التقويم البديل القائم على التقيم الذي } \\
\hline & & $\cdot, \mathrm{VN}$ & $17 V$ & $1 \cdot 7, \leqslant r$ & داخل المجمو عات & \\
\hline & & & 179 & $19 r, \leqslant V$ & الكلي & \\
\hline \multirow{3}{*}{$\cdot, \cdots 1$} & \multirow{3}{*}{$7 \cdot, \wedge 9$} & 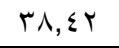 & r & $V\urcorner, \wedge \varepsilon$ & بين المجموعات & \multirow{3}{*}{ التقويم البديل القائم على |لماحظة } \\
\hline & & $\cdot \pi$ & $17 V$ & $1.0, r V$ & داخل المجمو عات & \\
\hline & & & 179 & $|\wedge r, r|$ & الكلي & \\
\hline \multirow{3}{*}{$\cdot, \cdots 1$} & \multirow{3}{*}{$\vee r, \wedge}$. & $\varepsilon \varepsilon, 1 \Gamma$ & r & $\Lambda \Lambda, Y_{\top}$ & بين المجموعات & \multirow{3}{*}{ التقويم البديل القائم على القلم والورقة } \\
\hline & &., 09 & $17 V$ & $99, \wedge 7$ & داخل المجموعات & \\
\hline & & & 179 & $1 \wedge \Lambda, 1 r$ & الكلى & \\
\hline \multirow{3}{*}{$\cdot, \cdots 1$} & \multirow{3}{*}{$09, Y 7$} & $\varepsilon r, 7 \wedge$ & $r$ & $\Lambda 0, r V$ & بين المجموعات & \multirow{3}{*}{ التقويم البديل القائم على الأقى } \\
\hline & & $\cdot, V Y$ & $17 V$ & $I r \cdot, r \Lambda$ & داخل المجمو عات & \\
\hline & & & 179 & $r \cdot 0,7 r$ & الكلي & \\
\hline \multirow{3}{*}{$\cdot, \cdots 1$} & \multirow{3}{*}{$\varepsilon 9, \vee \wedge$} & rq, r^ & r & $\vee \wedge, \diamond \vee$ & بين المجموعات & \multirow{3}{*}{ التقويم البديل القائم على } \\
\hline & & $\cdot, \mathrm{\vee} \wedge$ & $17 V$ & $1 \pi$, , VA & داخل المجمو عات & \\
\hline & & & 179 & $r 1 \cdot, r_{0}$ & الكلي & \\
\hline \multirow{3}{*}{$\cdot, \cdots 1$} & \multirow{3}{*}{$00,9 \vee$} & $\varepsilon 1, \cdot \varepsilon$ & $r$ & $\Lambda r, \cdot \Lambda$ & بين المجموعات & \multirow{3}{*}{ التقويم البديل القائم على |لمقابلة } \\
\hline & & $\cdot, \mathrm{VT}$ & $17 V$ & $M T, \varepsilon \varepsilon$ & داخل المجمو عات & \\
\hline & & & 179 & $r \cdot \varepsilon, O r$ & الكلي & \\
\hline \multirow{3}{*}{$\cdot, \cdots 1$} & \multirow{3}{*}{$79, \vee V$} & $\leqslant 1,10$ & $r$ & $\Lambda r, I V$ & بين المجموعات & \multirow{3}{*}{ الارجة الكلية } \\
\hline & & $\cdot, 09$ & $17 V$ & $99,0 \leqslant$ & داخل المجمو عات & \\
\hline & & & 179 & $M N Y, V Y$ & الكلي & \\
\hline
\end{tabular}

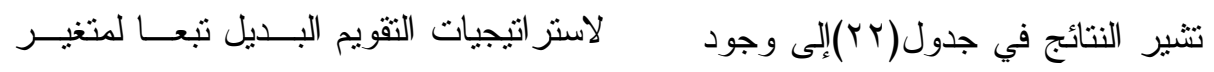

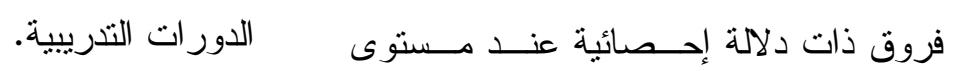

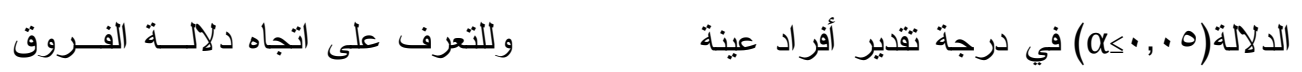

الدر اسة لدرجة استخدام معلمات اللغة العربية بالنسبة للمجالات تمّ استخدام اختبار (ثنيفيه)

للمقارنات البعدية، كما في جدول (rr). 


\section{جدول(r)}

المقارنات البعدية تبعا لمتغير الدورات التدريبية

\begin{tabular}{|c|c|c|c|c|c|}
\hline فأكثر & دورة إلى ست & دورة إلى ثثلاث & المتوسط & الفئات & المجالات \\
\hline *1,Or & - & - & $T, \wedge \Lambda$ & دورة إلى ثلاث دورات & \multirow{3}{*}{ القائمي على البديل } \\
\hline * I, Tr & - & 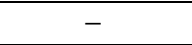 & $r, \cdot \Lambda$ & أربع إلى ست دور ات & \\
\hline- & - & - & $\varepsilon, \varepsilon$. & V دور ات فأكثر V دو & \\
\hline * $1,0 \leqslant$ & - & - & $r, V$. & دورة إلى ثلاث دورات & \multirow{3}{*}{ القائميم على البديل } \\
\hline$* 1, r$ & - & - & T,, & أربع إلى ست دور ات & \\
\hline- & - & - & $\varepsilon, Y \varepsilon$ & V دور ات فأكثر & \\
\hline$* 1,0 \leqslant$ & - & - & T,AY & دورة إلى ثلاث دورات & \multirow{3}{*}{ التقائميم علىيل التيل } \\
\hline * & - & - & $r, \cdot r$ & أربع إلى ست دور ات & \\
\hline- & - & - & $\varepsilon, r_{0}$ & V Vور ات فأكثر V د & \\
\hline$* 1, \leq 0$ & - & - & $r, .1$ & دورة إلى ثلاث دورات & \multirow{3}{*}{ التقويم علبيلي الملايل } \\
\hline $1, r_{0}$ & - & - & $r, r)$ & أربع إلى ست دور ات & \\
\hline- & - & 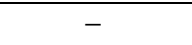 & $\varepsilon, \varepsilon 0$ & V Vور ات فأكثر V د V & \\
\hline$* 1,01$ & $\begin{array}{lllll}- & \\
\end{array}$ & - & $T, \Lambda)$ & دورة إلى ثلاث دورات & \multirow{3}{*}{ 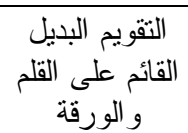 } \\
\hline * & - & - & $r, .9$ & أربع إلى ست دور ات & \\
\hline- & - & - & $\{, \S 1$ & V دور ات فأكثر V & \\
\hline *1,or & - & - & $Y, Y \leqslant$ & دورة إلى ثلاث دورات & \multirow{3}{*}{ التقائميم على البديل } \\
\hline *1,rr & - & - & $T, 90$ & أربع إلى ست دور ات & \\
\hline- & - & - & $\varepsilon, Y Y$ & V دور ات فأكثر & \\
\hline$\div 1,01$ & - & - & $r, V T$ & دورة إلى ثلاث دورات & \multirow{3}{*}{ القائم على البأداء } \\
\hline$* 1, Y 1$ & - & - & $r, .4$ & أربع إلى ست دور ات & \\
\hline- & - & - & $\varepsilon, Y V$ & V دور ات فأكثز & \\
\hline$* 1, \leqslant 9$ & - & - & $r, 74$ & دورة إلى ثلاث دورات & \multirow{3}{*}{ القائم على البديل } \\
\hline$* 1, r 9$ & - & - & T,YA & أربع إلى ست دور ات & \\
\hline- & - & - & $\varepsilon, 1 \mathrm{~V}$ & V دور ات فأكثر & \\
\hline **1,or & - & - & $r, v q$ & دورة إلى ثلاث دورات & \multirow{3}{*}{ الارجة الكلية } \\
\hline$* 1, r 1$ & - & - & $r, .1$ & أربع إلى ست دور ات & \\
\hline & - & - & $\varepsilon, Y Y$ & V دور ات فأكثر & \\
\hline
\end{tabular}

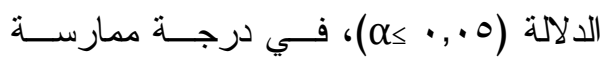

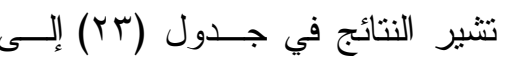

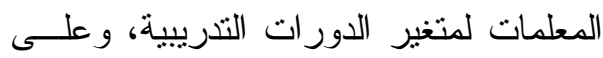
جميع مجالات أداة الدراسة و الدرجة الكليــة وجود فروق ذات دلالة إحصائية في جميـع للمجالات ولصالح فئة (V دور ات فــأكثر).

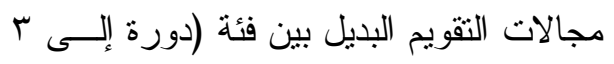
وتعزو الباحثة هذه النتيجة إلى أن المعلمــات

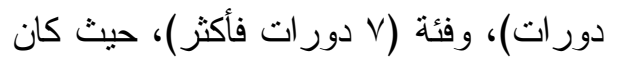

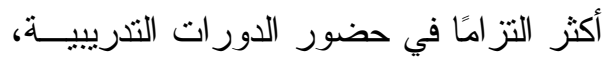

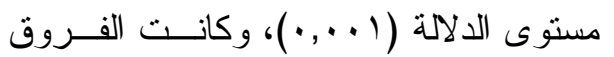

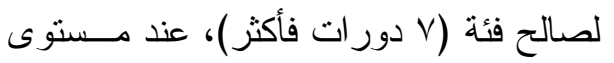


إدر الك أكثر من بقية الفئات بمبادئ التقــويم

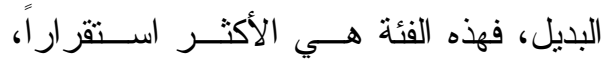

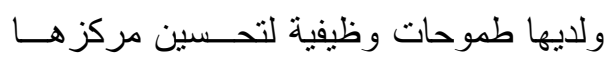
المهني. وقد اتفقت هذه النتيجـــة مـــع نتــائج در اسات سابقة، إلى وجود فروق ذات دلالة إحصائية تعود إلى حضور الدورات التدريبية

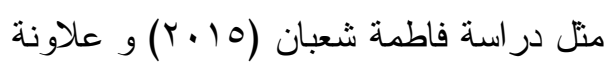

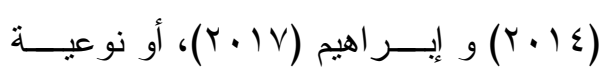

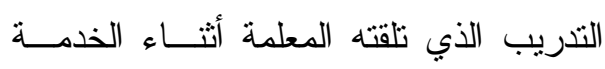

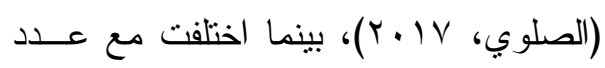

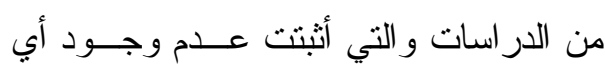
فروق ذات دلالة إحصائية تعود إلى الدورات

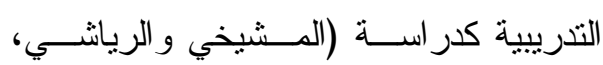
$\cdot(r \cdot) 1$

ملخــص نتـــائج الدراســــة والتوصــــات و مالمقترحات ملخص نتائج الدراسة

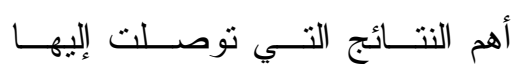

1- أظهرت نتــائج الدر اســـة أن درجــة استخدام معلمات اللغة العربية للتقويم البديل وأدو اته في المرحلة الابتدائيــة جاءت بدرجة كبيرة وبمتوسط حسابي

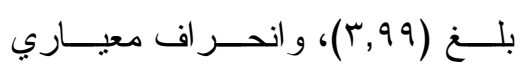
$\cdot(\cdot, 11)$

إضافة إلـى خبــرتهن التدريـسية ولــديهن معارف ومعلومات حول استر اتيجيات التقويم البديل، كما أن فئة (V دور ات فأكثر)، لديهن إدرالك أكثر من بقية الفئات بمبادئ الثقــــيم

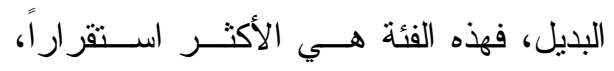

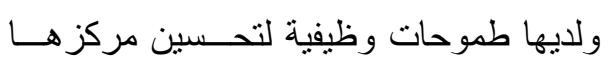

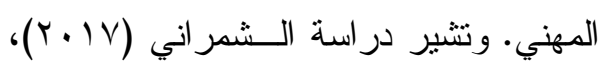
أن درجة ممارسات معلمات العلوم للتقــــيم

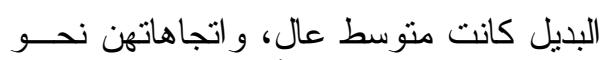
ممارسة التقويم البديل كانت بدرجة متوسطة

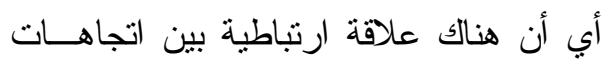

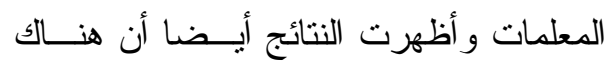

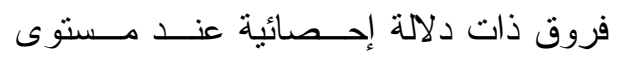

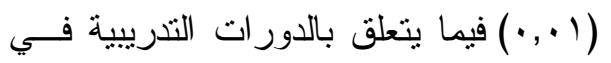
ردود معلمات الاقتصاد المنزلي على استبيان

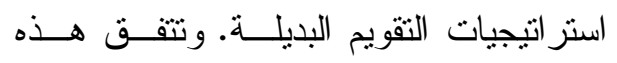

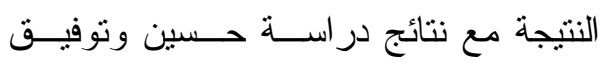

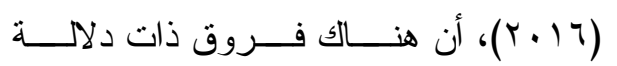

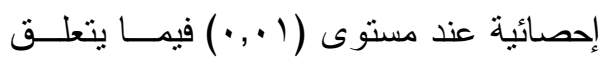

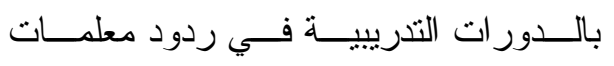
الاقتصاد المنزلي على استنيان استراتيجيات النقويم البديلة.

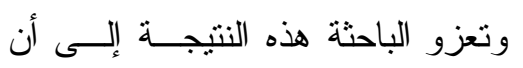

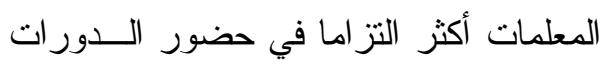
التدريبية، إضافة إلى ما يمتلكهن من معارف

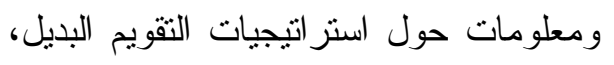

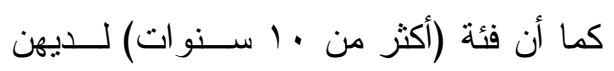




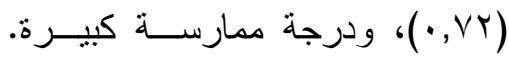

و أخيراً، مجال التقويم البــديل القـــائم

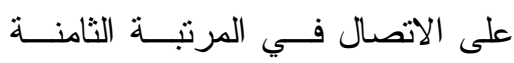

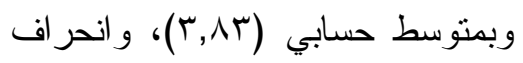

معياري (· (, •))، ودرجــة ممارســة

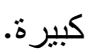

ץ- وجود فروق ذات دلالة إحصائية عند

مستوى الدلالة (0., بـ 2 في درجة

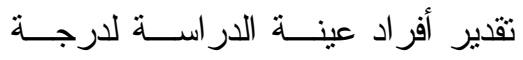

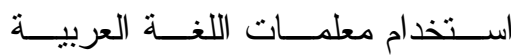

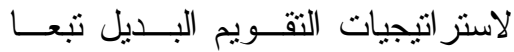

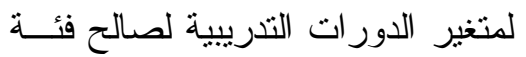

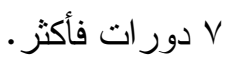

؟- وجود فروق ذات دلالة إحصائية عند

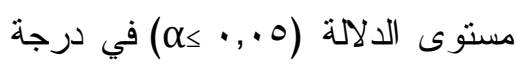

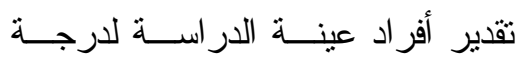

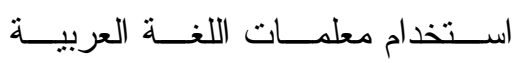

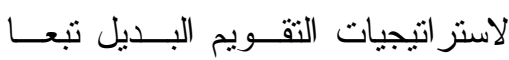

لمتغير سنوات الخبرة لصالح فئة أكثز

$$
\text { من · اسنوات. }
$$

0- وجود فروق ذات دلالة إحصائية عند

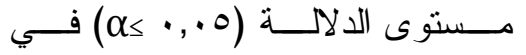

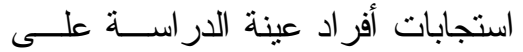

مجالات أداة الدراسة، تبعــــا لمتغيـــر

المر احل التنريسية وقد جاءت الفروق

لصالح فئة الصفوف العليا. r- أظهرت نتائج الدراسة أن مجالات أداة

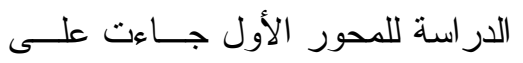

النحو الآتي: جاء مجال التقويم البديل

القائم على القلم و الورقة في المرتبــــة

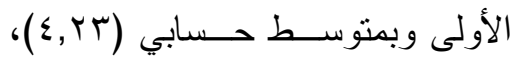

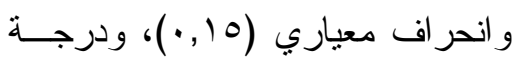

ممارسة كبيرة جداً. ثم المقابلـــة فــي وني

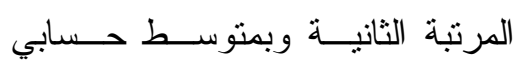

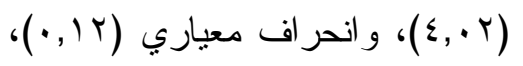

ودرجة ممارسة كبيرة. يلي ذلك تقويم

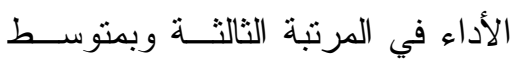

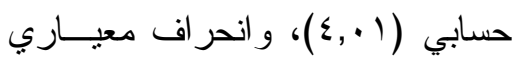

(7 (, •)، ودرجة ممارسة كبيرة. أما

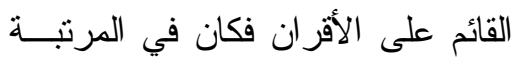

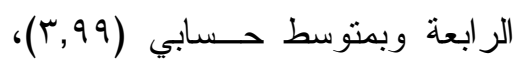

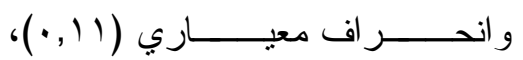

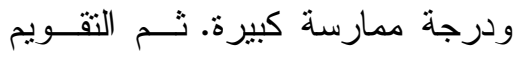

القائم على ملفات الإنجاز في المرتبــــة

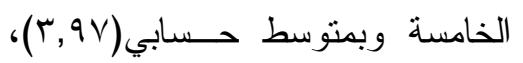

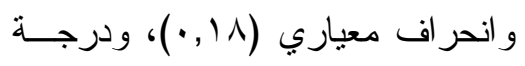

ممارسة كبيرة. يليـــهـ التقـــويم القــائم

على الملاحظة في المرتبة الـسادسة

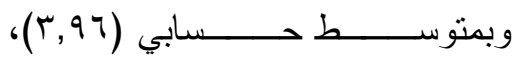

و انحر اف معياري (9 (19.))، ودرجــة

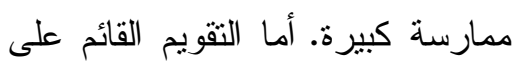

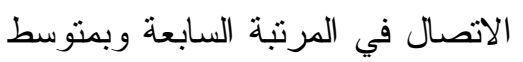

حسابي (19,9)، و انحر اف معيــاري 


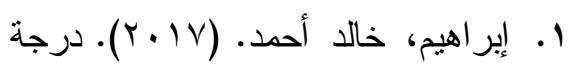

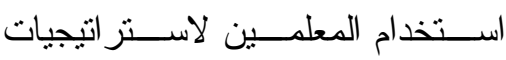
التقويم البديل و أدواته: معلمو محافظة

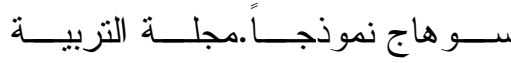
بالإسكندرية، VV (1)، Y. أبو جزر، ؛حمـــ أحمـد. (Y (Y. Y). مدى استخدام بطاقة الأداء المتـــوازن

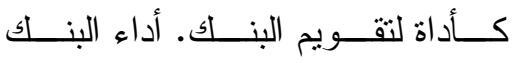
الإسلامي الفلسطيني (رسالة ماجستير

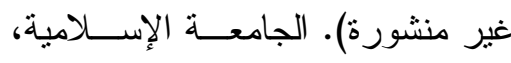
غزة، فلسطين. r. أبو عو اد، فريال محمد، وأبو ســنينة،

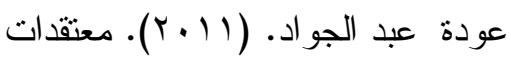

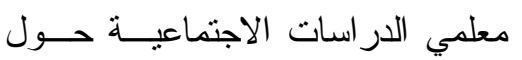
التقويم البديل في المرحلة الأساسـية التية

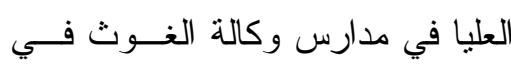
الأردن .مجلة جامعة القدس المفتوحسـة

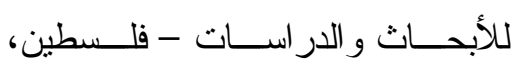
. r T ـ. الأحمدي، رشا عبد الكريم، وبريكيت،

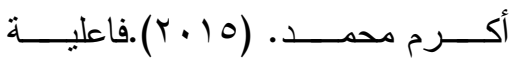
استر اتيجية مقترحة قائمة على الــدمج بين الفصول المقلوبة و التقويم البــديل

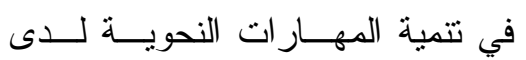
طالبات الصف الثاني الثانوي.در اسات عربية في التربيــة وعلــــ الــنفس،
في ضوء النتائج التي توصلت إليهــا

الدر اسة نوصي الباحثة بما يلي: - مر اعاة دمج التقويم البديل عند تــصميم منهج اللغة العربية. - أن تعمل المعلمة على إثر الك الطالبــات باختيار استر اتيجيات التقويم البديل التي لتئل تنتاسب مع أدائهن، وتشبع حاجاتهن. - أن توظف المعلمة بعض أنماط التقــويم

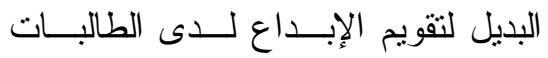

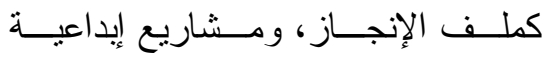
للطالبات.

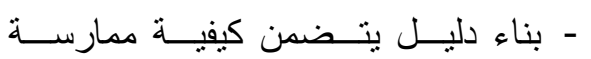

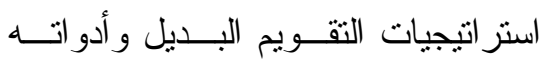
المختلفة من قبل معلمات اللغة العربيــة للمرحلة الابتدائية.

ثالثا: مقترحات الدراسة

في ضوء ما تم التوصل إليه من نتــائج،

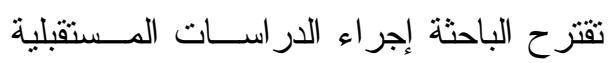
الآتية:

- إجر اء دراسة لمعرفة أثز التقويم البــديل على دافعية الطالبات نحو التعلم. - التقويم البديل وعلاقته بتحسين العمليـــة التعليمية. - إجر اء در اسة مماتله على مر احل التعليم

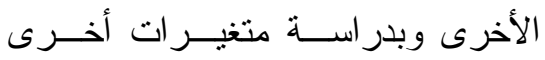
كالمؤهل العلمي. 


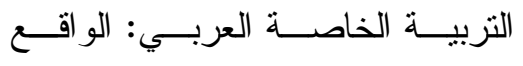

و المأمول، الجامعة الأردنيــة، كليـــة

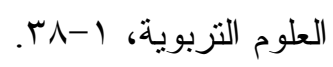

9 ـ. التزركي، خلــود إبر اهيم،و الــشمر اني،

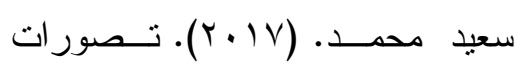

معلمات العلوم في مدينـــة المجمعسـة

حول النقويم البديل.مجلة كلية التربية، معلية

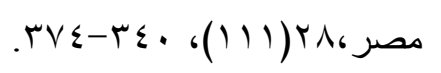

• ا. الأشقر ، محمد حسن أحمد. (10 (Y).

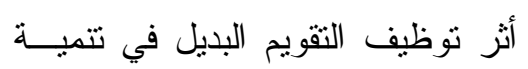

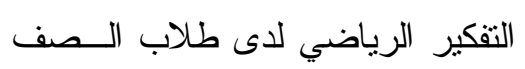

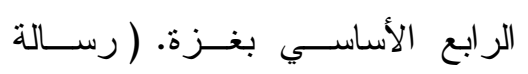

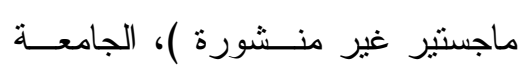

الإسلامية، غزة، فلسطين.

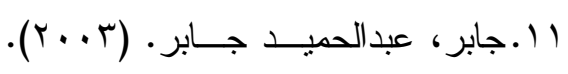

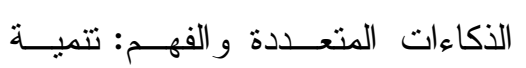

وتعميق. الطبعة الأولى، القاهرة: دار

$$
\text { الفكر العربي. }
$$

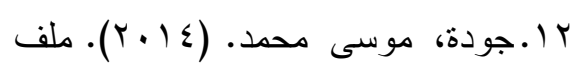

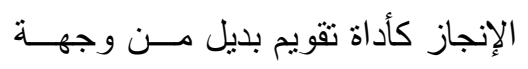

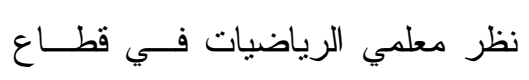

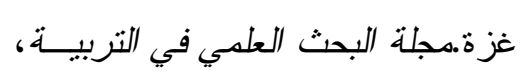

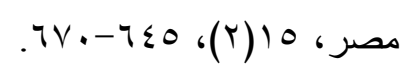

rا. الحارثي، صبحي ســيد. (10 • (1).

أساليب الثقويم البـديل كمــــا ير اهــــا

الطلاب وأعضاء هيئة التدريس فـي لئي
المملكة العربيــة الـسعودية، (ON)، .YYT-IVq

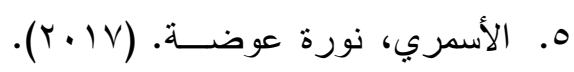

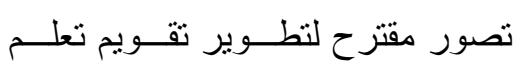

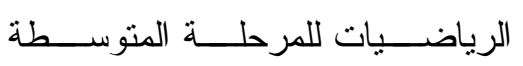

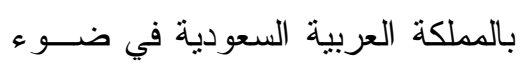

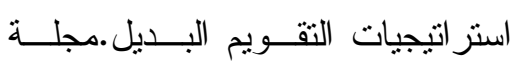

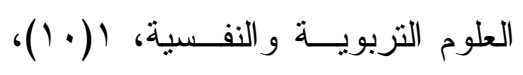

$.9 \leqslant-7$.

7. الأصقه، حصة محمــد، و الــدو لات،

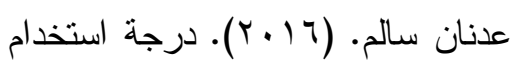

معلمات المرحلة المتوسطة لأسـاليب

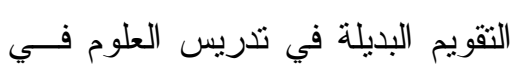

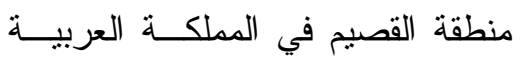

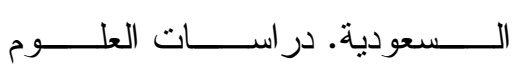

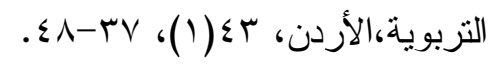

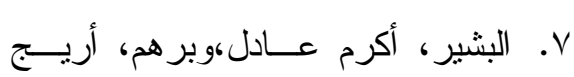

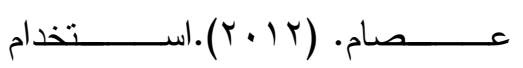

استز اتيجيات التقويم البديل و أدو اته في

تقويم تعلم الرياضيات و اللغة العربيــــة

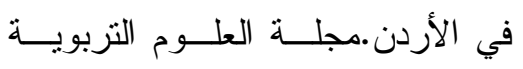

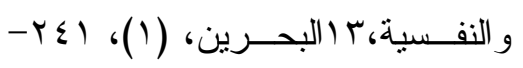

$$
\text { .rV. }
$$

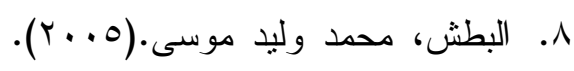

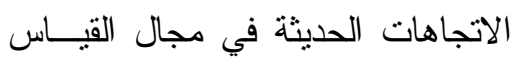

و الثقويم وتطبيقاته في ميدان التربيـــة

الخاصة.ورقة مقدمــة إلـى مـــؤتمر مئس 
1 ا ـ الحسين، سمية حامد، وفــرج، إلهــام

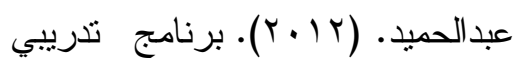

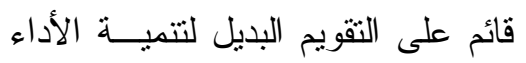

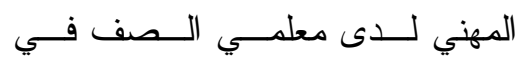

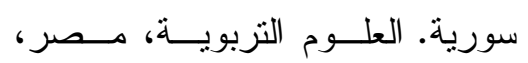
•

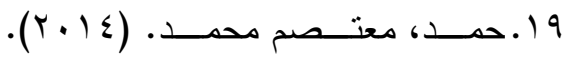
أساليب الكفاية التواصلية في ضـــوء مفهوم التقويم التزبوي البـديل لــدى متعلمي اللغة العربية الناطقين للغــات أخــرى. مجلـــة العربيــة للنـــاطقين

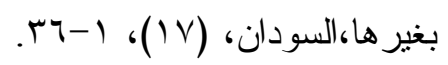

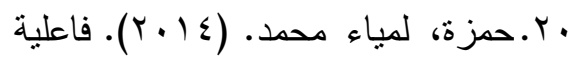
برنامج تدريبي لتتمية بعض أســاليب

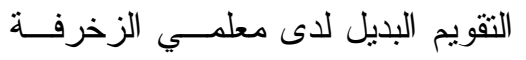

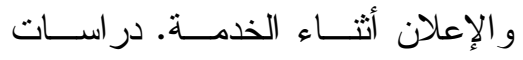

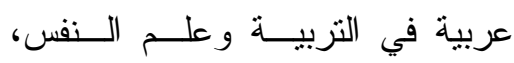

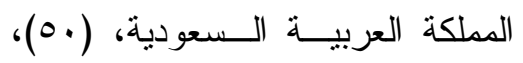
. $\Gamma \varepsilon \varepsilon-\mu \mid V$

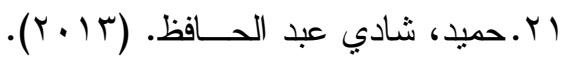
أثز توظيف أساليب التقويم البديل فــي تتمية التقكير التأملي ومهار ات رستح الخر ائط بالجغر افيــا لــدى طالبـــات

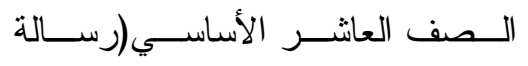
ماجـستير غيــر منــشورة). غـزةة الجامعة الإسلامية، كلية التربية.
بعض الكليات بجامعة شقر اء.المجلـــة

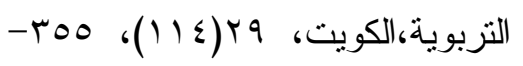
हाए ع ا ـ الحجيلي، محمد عبدالعزيز • (T 1 • (Y).

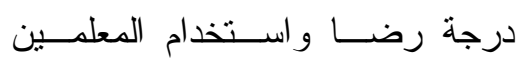
بالمملكة العربية الـسـعودية لأســاليب

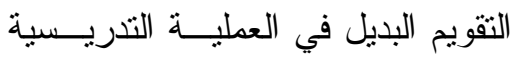
بالتعليم العام ومعيقات استخدامه.مجلة

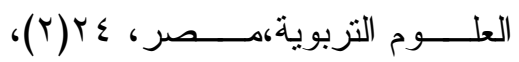
.rTा-r.O

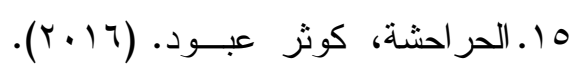
و اقــع اســـتخدام معلمــــي العلــــوم لإستر اتيجية التقويم البديل و أدو اته في

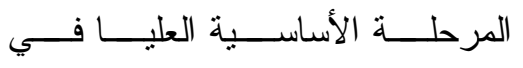

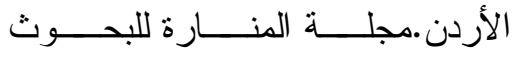

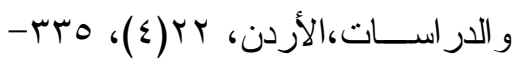
.rVT

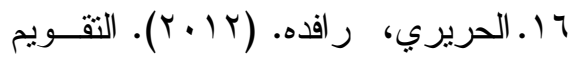

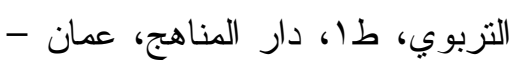

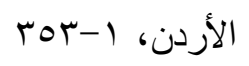

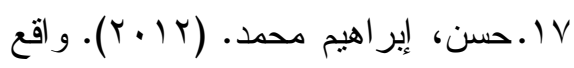
ممارسات معلمي الرياضيات بالمرحلة الرئ

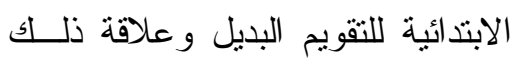
بمعتقداتهم حوله. در اسات عربية فـي لئه التربية و علم النفس، المملكة العربيـــة

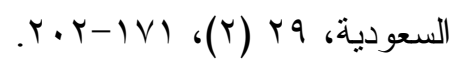


التعليمية.فكر و إبداع، مــصر، ـ10 ـ-

.0 .7

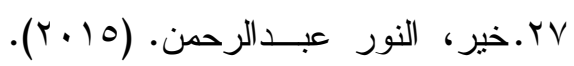

التقويم التزبوي البديل ودوره الإيجابي

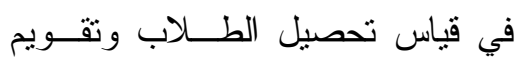
أدائهم بمر احل التعليم المختلفة: دراسة تحليلية نظرية.مجلة البحوث النفـسية

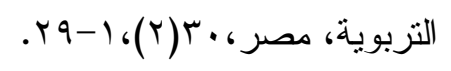

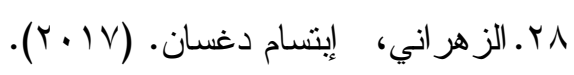

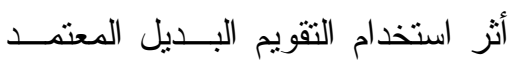
على الأداء في مقـرر ات الدر اســات الإجتماعية على تحصيل و اتجاهــات

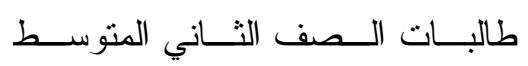

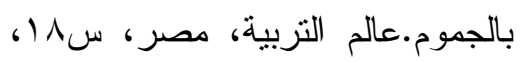
$. r \leqslant-1 \cdot(0 \Lambda)$

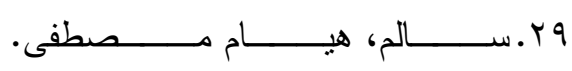

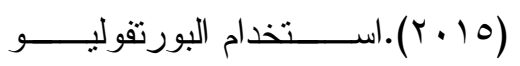

كاستر اتيجية للتقويم البديل في تتميــة

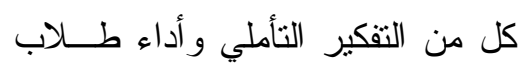
المرحلة الجامعية.در اسات عربية في التربية وعلم النفس، المملكة العربيـــة السعودية، ( • (T)، IV9

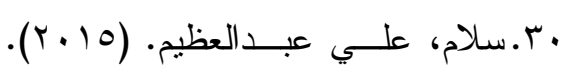
التقويم البديل: مدخل للارتقاء بــأداء المعلم وتطوير برامج إعداده. الهيئــة

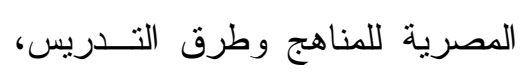
مصر، المعناله r. الحميدي، حامد عبداله، و الظفيـري،

محمد دهيم. (T ( • (Y). مدى استخدام

معلمـــي اللغــــة العربيــــة بالمر حلــــة المتوسطة بدولة الكويـــت لأســاليب التقويم البديل من وجهة نظر هم. مجلة

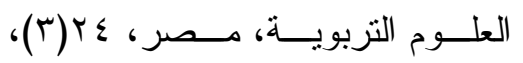
$.1 \cdot-17 V$

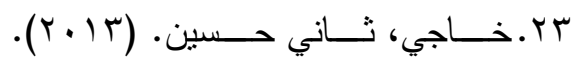
اسهامات استر اتيجيات التقويم البــديل في تحسين جودة التعليم. مجلة كليــة

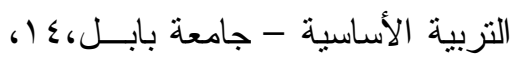

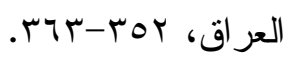

ع r. الخالدي، عـادي كـريم. (ع إب).

درجة ممارسة معلمي العلوم الطبيعية بالمرحلة المتوسطة لمهار ات التقــويم البديل.مجلة كلية التربية، مــصر، كا،

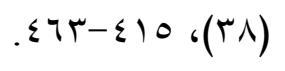

0. مخاطر محمــود رشــدي وآخــرون. (1911). طرق تدريس اللغة العربية

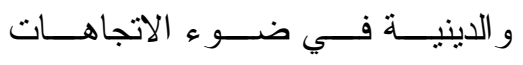
الحديثة.دار المعرفة الجامعية للطبــع و النشر و التوزيع، القاهرة، مصر ، 1דr. خليفة، عبدالسلام الثيباني. (ع ا • ( ). الإتجاهات المعاصـــرة فــي التقــويم التربوي ودور ها في تطوير العمليــة 


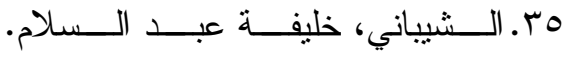

$$
\begin{aligned}
& \text { اس. ســــ طـــارق \&ســمير فيــاض. }
\end{aligned}
$$

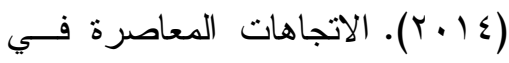

$$
\begin{aligned}
& \text { التقويم التزبوي ودور ها في تطـــوير } \\
& \text { العملية التعليمية.فكر و إبداع: ر ابطــــة فئة }
\end{aligned}
$$

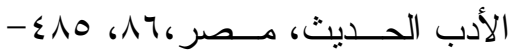

$$
\begin{aligned}
& .0 .7 \\
& \text { بr. الصلوي، محمد علي. (YV) (Y). و اقع } \\
& \text { ممارسة معلمـي العلــوم بمحافظـــة } \\
& \text { العارضة لأســاليب التقـــيم البــديل. }
\end{aligned}
$$

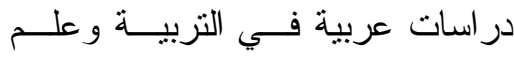

$$
\begin{aligned}
& \text { النفس،المملكة العربية السعودية، AN، } \\
& . \Sigma Y r-\varepsilon \cdot r \\
& \text { V. الضمور، سالم عبدالحميد، وعــوض، }
\end{aligned}
$$

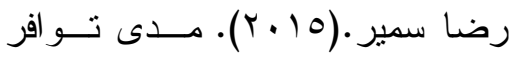

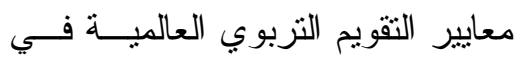

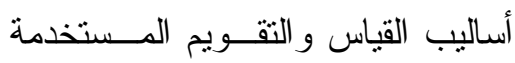

$$
\begin{aligned}
& \text { لاى معلمــي الرياضـــات بالمملكـــة }
\end{aligned}
$$

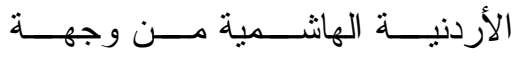

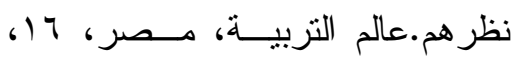

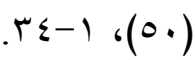

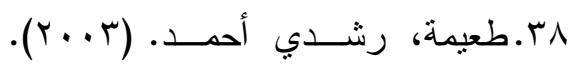

$$
\begin{aligned}
& \text { نماذج من الاختبار ات الموضوعية في }
\end{aligned}
$$

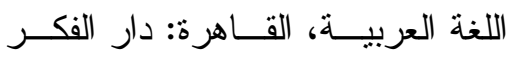

$$
\begin{aligned}
& \text { الجامعي. }
\end{aligned}
$$

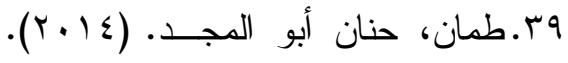

$$
\begin{aligned}
& \text { أثز توظيف بعض أســاليب التقــويم }
\end{aligned}
$$

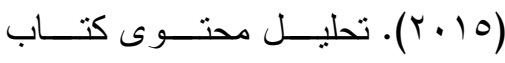

$$
\begin{aligned}
& \text { المطالعة المقرر للصف الرابع الأدبي } \\
& \text { في ضو ء الميول القر ائية للطلبة. مجلة } \\
& \text { كلية التزبية الأساسية للعلوم التزبويـــة فئه }
\end{aligned}
$$

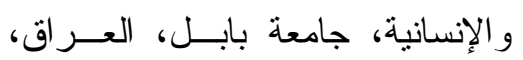

$$
\begin{aligned}
& .17-1 \text { ، ( } Y \varepsilon)
\end{aligned}
$$

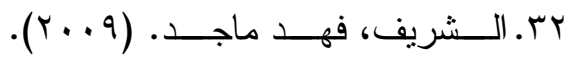

$$
\begin{aligned}
& \text { برنامج مقتر ح لتتمية مهار ات استخدام } \\
& \text { التقويم البديل لــدى معلمــات اللغــــة } \\
& \text { الإنجليزية بالمرحلة المتوسطة.التربية، }
\end{aligned}
$$

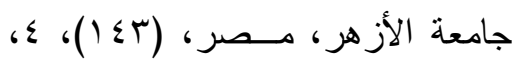

$$
\begin{aligned}
& .01 V-\Sigma T V \\
& \text { rr.شعبان، فاطمــة عاثــور . (10 • r). } \\
& \text { درجــة ممارســـة معلمــات التربيـــة } \\
& \text { الأسرية لاستر اتيجيات التقويم التربوي }
\end{aligned}
$$

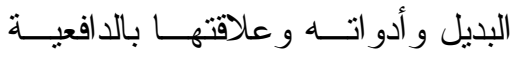

$$
\begin{aligned}
& \text { للتعلم لاى تلميذاتهن. المجلة التربوية والية }
\end{aligned}
$$

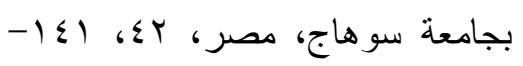

$$
\begin{aligned}
& \text { Trt }
\end{aligned}
$$

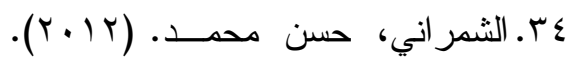

$$
\begin{aligned}
& \text { التحول من التقويم التقليدي إلى التقويم } \\
& \text { البديل في برنامج تعلم اللغة العربيـــة }
\end{aligned}
$$

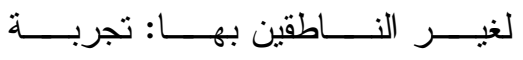

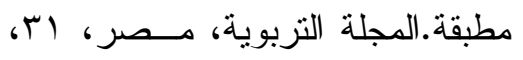

$$
\begin{aligned}
& \text {. }\{r-1
\end{aligned}
$$


و عصر المعرفة: الفرص و التحــديات تحت شعار معلم متجدد لعالم متغيــر • جامعة الملك خالـــد، كليـــة التربيـــة،

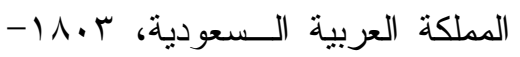
.1 กิN

ع ـ ـ عو اودة، اسماعيل \& محمد المقابلـــة. (T (Y (Y). درجة ممارسة استر اتيجيات التقويم الواقعي لدى معلمي ومعلمات المرحلة المتوســـة فــي محافظـــة الدمام.مجلة جامعــة طيبــة للعلـــوم التزبوية، المملكة العربية الـسعودية، $.09-\varepsilon r 6(1) 11$

0ـ ـ العر ابي، محمد سعد. (ع . . ب). فعالية

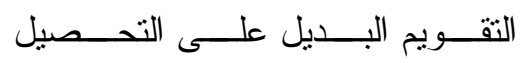
و التو اصل وخفض قلــت الرياضـــــات لتلاميذ المرحلة الإبتدائية. ورقة مقدمة

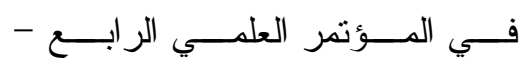
رياضيات التعليم العام فـي مجتمــعـع

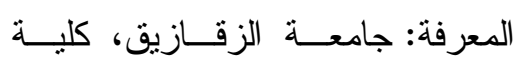
التربية ببنهـــا، الجمعيــة المــصرية

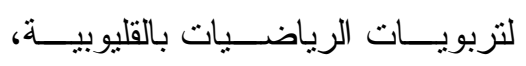
مصر،

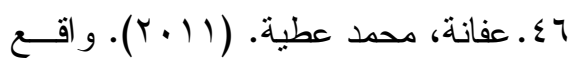
استخدام معلمي اللغة العربية لأساليب

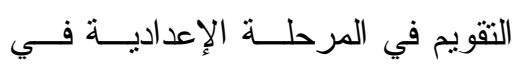
وكالة الغوث الدولية في قطاع غــزة في ضوء الاتجاهات الحديثة (رســالة
التطبيقية لدى طلاب المدارس الثانوية التجارية في ضـــو ء مــــلـ تـــسن الجودة المستمر • مجلة كلية التربيــة،

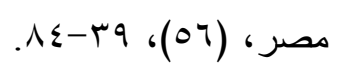

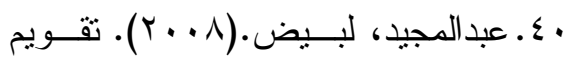
الكفاءة مفهوم جديد في التذريس.مجلة العلوم الإنسانية، (·r)، 9 ( $9-70$. اءـ عبداله، فيصل حمود الملا. (q . . r). مدى استخدام معلمي التربية الرياضية

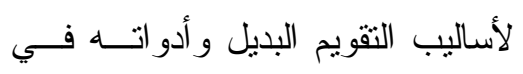
تقويم طلبة المرحلة الثانوية.الرياضـــة (علوم وفنون)، مصر ، عا(Y)، 99 .117 Y ـ ـ عبــــدالو هاب، عبدالناصـــر أنــيس. (T ا • Y، فبر اير).التوجه نحو أساليب

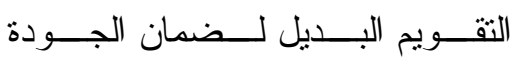
بمؤسسات التعليم العــالي: مقــابيس التقدير المتلرجة ندونجاً .ورقة مقدمة في المؤتمر العلمي الــدولي الأول رؤية اسنتر افية لمستقبل التعليم فـي مصر و العالم العربــي فـي ضـــوء التغبير ات المجتمعية المعاصرة، كلية التربية، جامعة المنصورة،مصر ، $.11 \cdot v-1 \cdot v r$

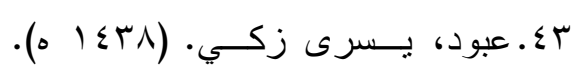

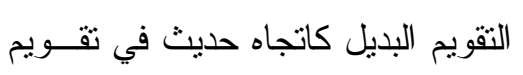

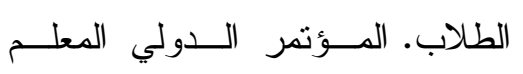




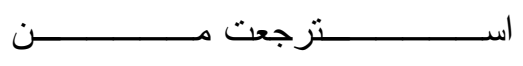

http://www.moe.gov.jo/Files/(1

2-5-2010)(3-49-48\%20PM).pdf

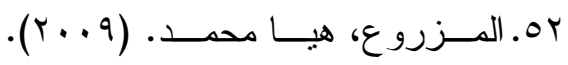

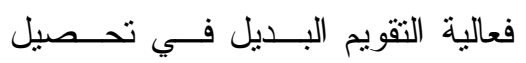

مفاهيم البحث التزبوي وزيادة فعاليــة

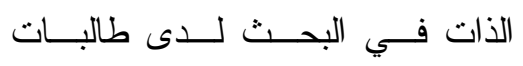

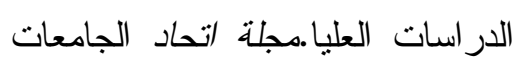

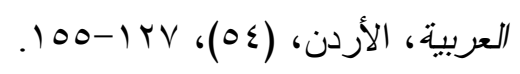

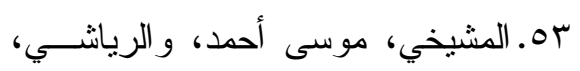

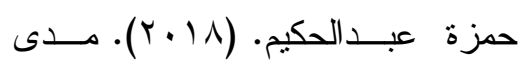

استخدام معلمي الدراسات الاجتماعية

و الوطنية لاستر اتيجيات التقويم البديل

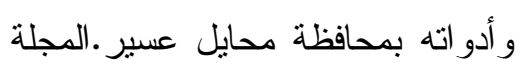

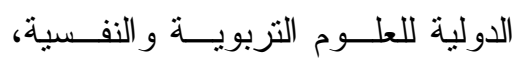

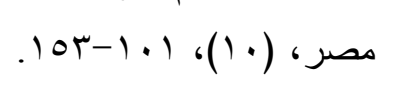

ــ المطرفي، ثامر بن هز اع بن عــواد.

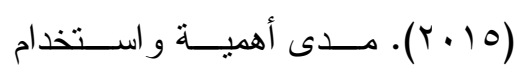

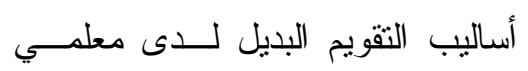

العلوم الثرعية بالمرحلة الثانوية وأهم

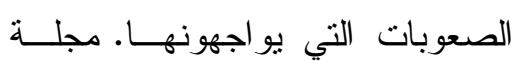

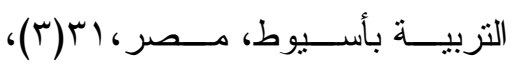

$$
7.1-0 \leq \varepsilon
$$

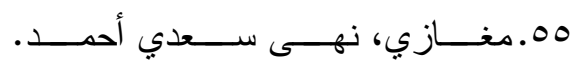

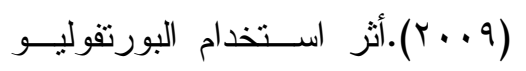

كأداة للتقويم البديل على تحقيق أهداف

تدريس مادة خدمة الجماعة: دراســة
ماجسنتير غير منشورة).كلية التزبيــة، الجامعة الإسلامية، غزة، فلسطين.

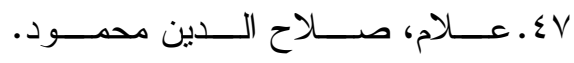

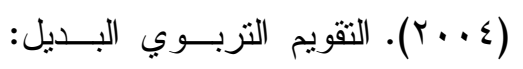

أسسه النظرية و المنهجية ونطبيقاتــه

الميدانية. القاهرة: دار الفكر التربوي.

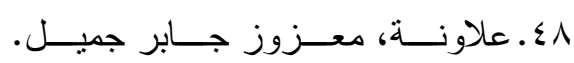

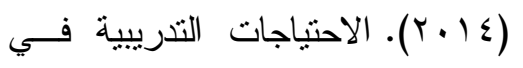

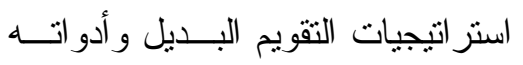

عند معلمي الرياضيات فـــي مديريـــة

التربية و التعليم في مدينة نابلس. مجلة

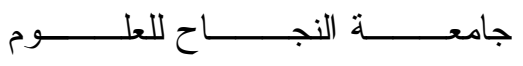

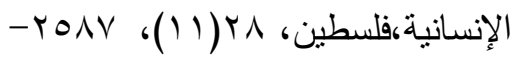

. YTIN

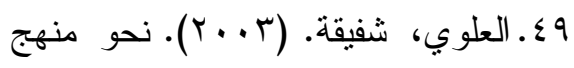

بديل لتقويم العلوم اللغوية: علم النحو

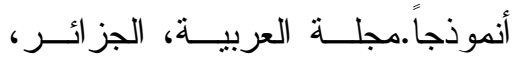

$$
\text { .7.-ะ9،(1) }
$$

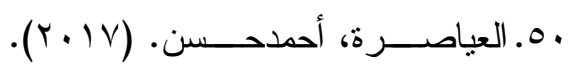

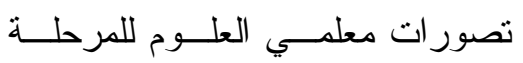

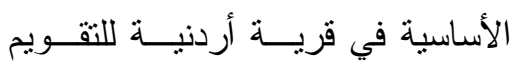

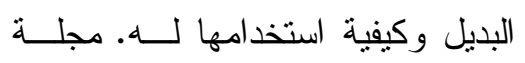

المشكاة للعلوم الإنسانية و الاجتماعية،

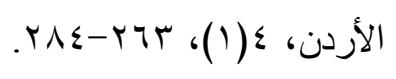

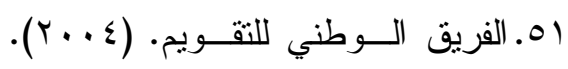

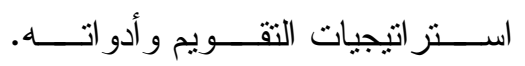


Assessment Styles and School Results. ProcediaSocial and Behavioral Sciences, 203, 280-284.

60. Caliskan, H., \& Kasikci, Y. (2010). The application of traditional and alternative assessment and evaluation tools by teachers in social studies. Procedia-Social and Behavioral Sciences, 2(2), 4152-4156.

61. Dikli, S. (2003). Assessment at a Distance: Traditional vs. Alternative

Assessments. Turkish Online Journal of Educational Technology-TOJET, 2(3), 13-19.

62. Hasyim Asy'ari. (2018). Characteristics of the Arabic language and its place in the Islamic religion. Journal $\mathrm{Al}$ Bayan, 10, 54-74.

63. Hussein, A., \& Tawfik, F. (2016). The Degree of Use Alternative Assessment Strategies by Home Economics Teachers and the Relationship with their Female Students' Selfefficacy in Najran Region. Art and Design Studies, 39, 38-52.

64. Kleinert, H. L., \& Kearns, J. F.(2010). Alternate Assessment for Students with

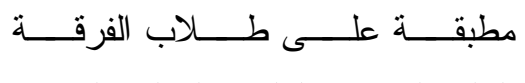

الثالثة.المؤتمر العلمي الدولي الثـاني

و العشرون للخدمة الاجتماعية (الخدمة

الاجتماعية وتحسين نوعية الحبــاة)،

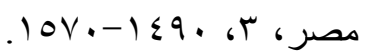

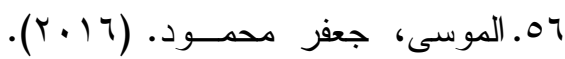

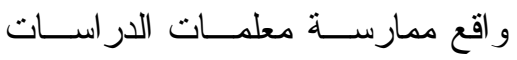

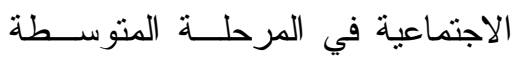

لأساليب التقويم البــديل.مجلــــة كليـــة

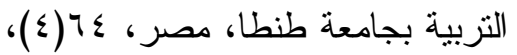

r

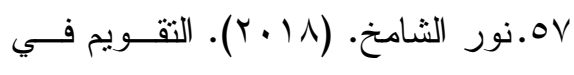

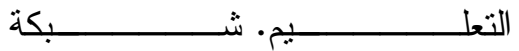

الألوكة

01.زيتون، كمال عبد الحميـد، والبنــا،

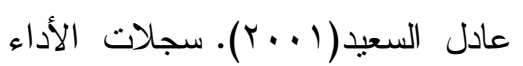

وخر ائط المفاهيم : أدو ات بديلـــة فــي لفي

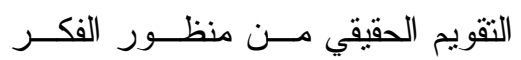

البنائي. بحث مقدم للمؤتمر العربـي مئي

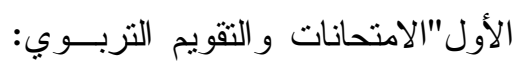

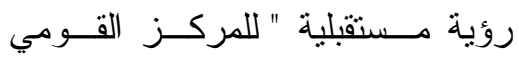

للامتحانات و التقويم التزبوي في الفترة

من r r- ك ديسسمبر •دار الـضيافة

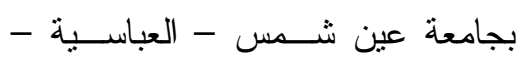

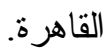

59. Bota, O. A., \& Tulbure, C. (2015). Analyzing the Relationship Between 
69. Nugraha, I. (2018, May). The use of drawing as an alternative assessment tool in biology teaching. In Journal of Physics: Conference Series (Vol. 1013, No. 1, p. 012016). IOP Publishing.

70. Sandford, B. A., \& Hsu, C. C. (2013). Alternative assessment and portfolios: Review, reconsider, and revitalize. International Journal of Science Studies, 1, 215-221.

71. Selahattin, A. \& Ozpinar, I. (2010).Assessmentin mathematics course and evaluating primary school coursebooks in term of assessment, Procedia Social and Behavioral Sciences, 2, 4157-4163.

72. Semire Dikli. (2003). Assessment at a distance: Trditional vs. Alteranative Assessment. The Turkish Online Journal of Eductional Technology, 2(3), 13-19.

73. Svinicki, M. D. (2005, March). Authentic assessment: Testing in reality. New Directions for Teaching and Learning, (100), 23-29.
Significant

Cognitive

Disabilities: An Educator's Guide. Brookes Publishing Company.

65. Letina, A. (2015). Application of traditional and alternative assessment in science and social studies teaching. Croatian Journal of Education, 17, 137-152.

66. Li-Ching Hung. (2016). Alternative Assessment: can portfolio Assessment have positive impact on eflaborginal students learning outcome, international journal of management and applied science, 2 (9), 23947926.

67. Lopes, L. S. (2015). Alternative assessment of writing in learning English as a foreign language: analytical scoring and selfassessment (Master thesis). Collage of Graduate Studies, Bridgewater State University, USA.

68. Nasri, N., Roslan, S. N., Sekuan, M. I., Bakar, K. A., \&Puteh, S. N. (2010). Teachers' perception on alternative assessment. Procedia-Social and Behavioral Sciences, 7, 37-42. 